University of South Florida

DIGITAL COMMONS

Digital Commons @ University of

@ UNIVERSITY OF SOUTH FLORIDA

South Florida

USF Tampa Graduate Theses and Dissertations

USF Graduate Theses and Dissertations

October 2020

\title{
A Multi-City Investigation of the Effect of Holidays on Bikeshare System Ridership
}

Lori Palaio

University of South Florida

Follow this and additional works at: https://digitalcommons.usf.edu/etd

Part of the Urban Studies and Planning Commons

\section{Scholar Commons Citation}

Palaio, Lori, "A Multi-City Investigation of the Effect of Holidays on Bikeshare System Ridership" (2020). USF Tampa Graduate Theses and Dissertations.

https://digitalcommons.usf.edu/etd/8476

This Thesis is brought to you for free and open access by the USF Graduate Theses and Dissertations at Digital Commons @ University of South Florida. It has been accepted for inclusion in USF Tampa Graduate Theses and Dissertations by an authorized administrator of Digital Commons @ University of South Florida. For more information, please contact digitalcommons@usf.edu. 
A Multi-City Investigation of the Effect of Holidays on Bikeshare System Ridership

by

\title{
Lori Palaio
}

\author{
A thesis submitted in partial fulfillment \\ of the requirements for the degree of \\ Master of Science in Civil Engineering \\ Department of Civil and Environmental Engineering \\ College of Engineering \\ University of South Florida
}

Co-Major Professor: Robert L. Bertini, Ph.D.

Co-Major Professor: Michael Maness, Ph.D.

Fred Mannering, Ph.D.

Date of Approval:

October 15, 2020

Keywords: Micromobility, Calendar Days, Subscriber, Casual, Special Events

Copyright $@ 2020$, Lori Palaio 


\section{Dedication}

This thesis is dedicated to my family who encouraged me to pursue a higher education. They have always told me that "knowledge is power" and to never stop learning. My family has

continuously taught me to be hardworking and to never quit when it is easy. They offered me the best advice and without them, I would not be where I am today.

I would also like to thank my grandparents for supporting me and listening to me talk about my continued education journey. They always believed in me and told me that I will succeed in anything I do. Lastly, I would like to thank my boyfriend for inspiring me to become a better researcher and guiding me throughout my research. 


\section{Acknowledgments}

This thesis is funded by the Center for Urban Transportation Research at the University of South Florida, along with the FHWA Dwight David Eisenhower Transportation Fellowship. The author gratefully acknowledges support provided by the Center for Teaching Old Models New Tricks (TOMNET), a University Transportation Center sponsored by the US Department of Transportation through Grant No. 69A3551747116. The author is thankful for her advisors, Dr.

Robert L. Bertini and Dr. Michael Maness for their continuous support and assistance during her educational career. The author also shows gratitude to Dr. Fred Mannering for teaching the author econometric modeling techniques to strengthen her thesis. Lastly, the author would like to thank the bikeshare agencies that provided the data for this analysis. 


\section{Table of Contents}

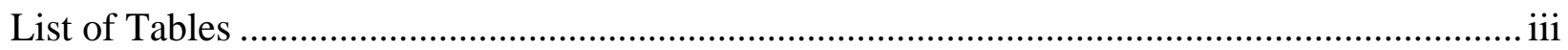

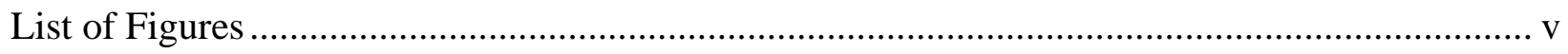

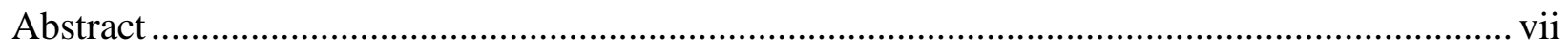

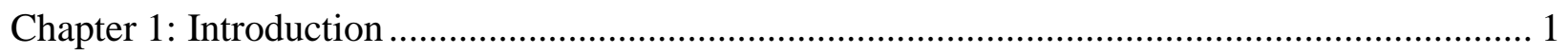

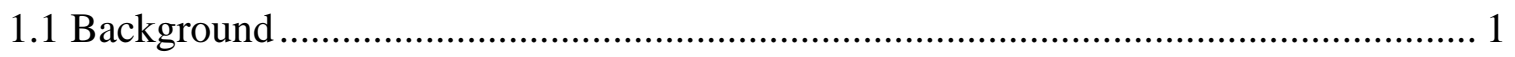

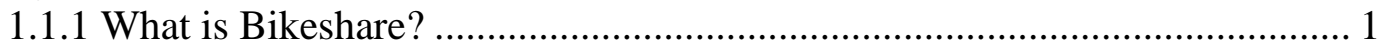

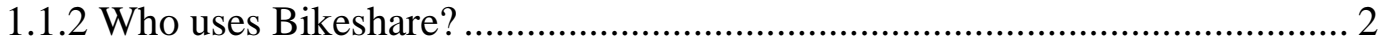

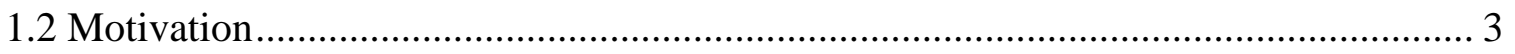

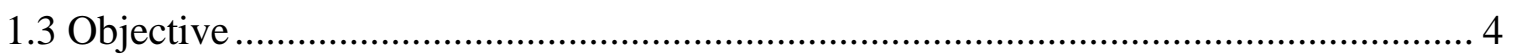

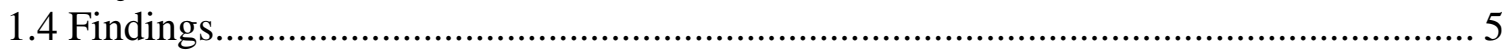

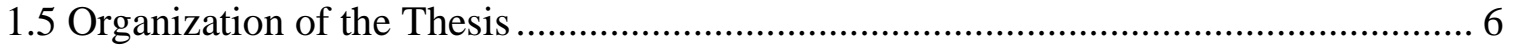

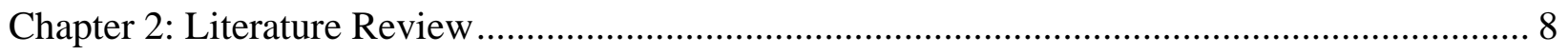

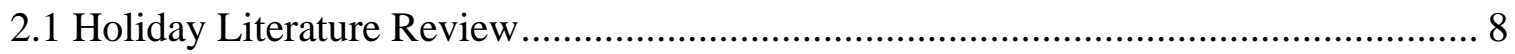

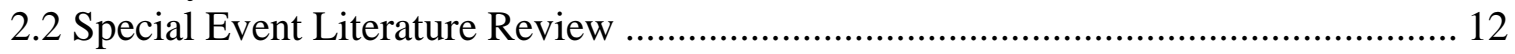

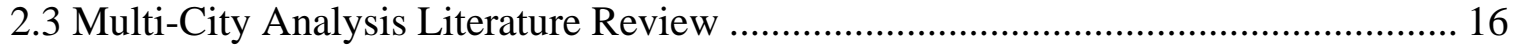

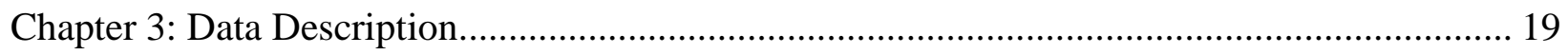

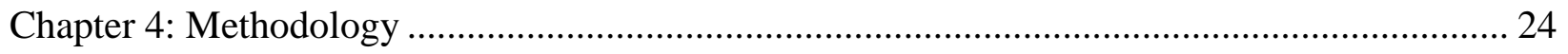

Chapter 5: Theorizing Bikeshare Ridership on Special Calendar Days ................................. 28

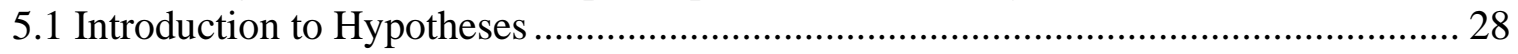

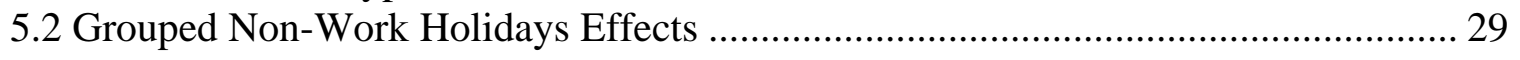

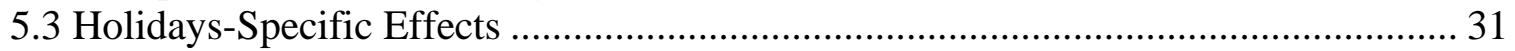

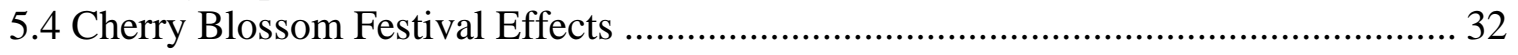

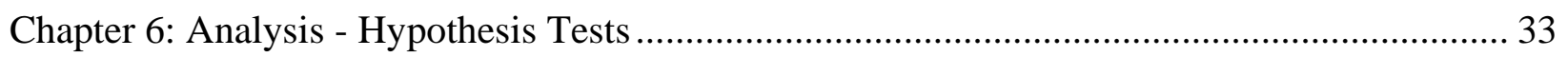

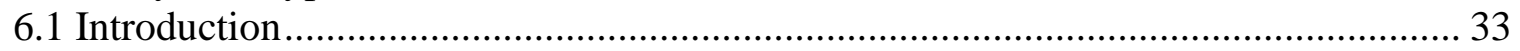

6.2 Grouped Non-Work Holidays Effects ........................................................ 33

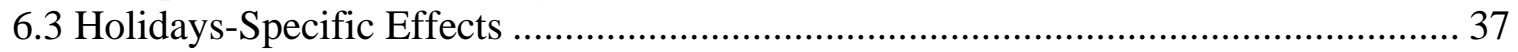

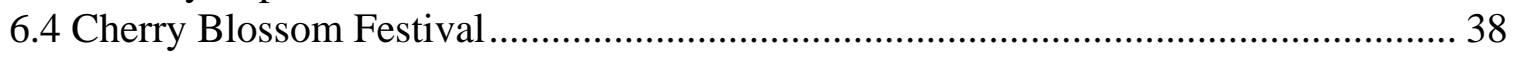

Chapter 7: Results - Individual Holiday Effects Models ....................................................... 43

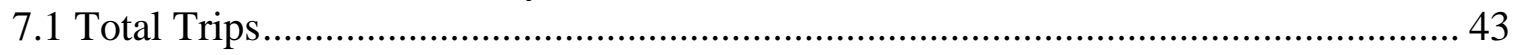

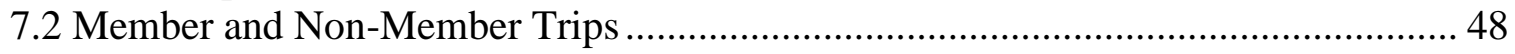




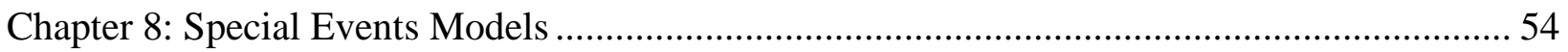

8.1 Classifying Special Events................................................................................... 54

8.2 Results - Special Event Models............................................................................ 55

8.3 Analysis - Special Event Impacts by Operational Characteristic................................ 57

8.3.1 Event Location ........................................................................................ 57

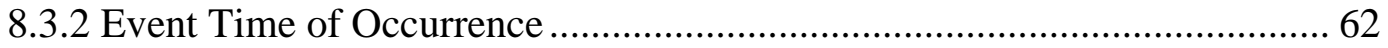

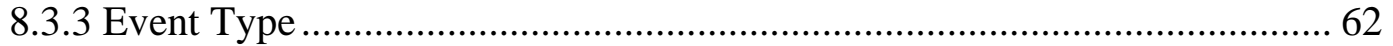

8.3.4 Event Market Area and Expected Attendance …………………………........ 62

8.3.5 Audience Accommodation....................................................................... 63

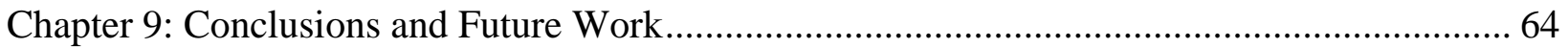

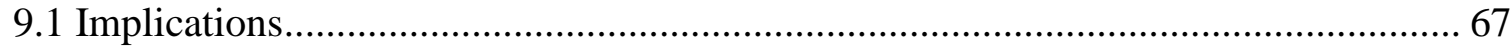

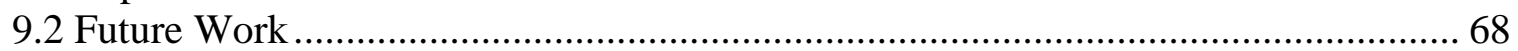

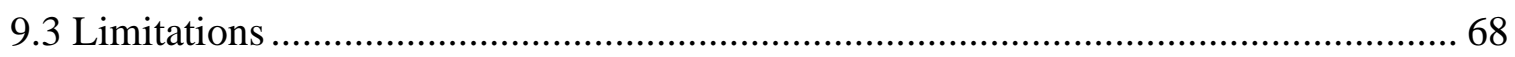

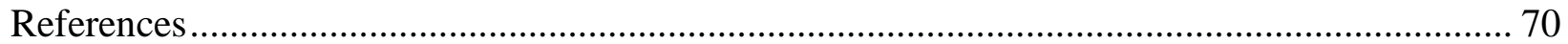

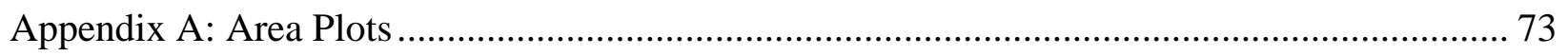

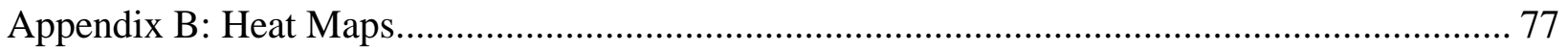

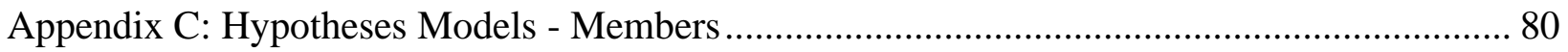

Appendix D: Hypotheses Models - Non-Members ................................................................... 97 


\section{List of Tables}

Table 2.1: Literature Review Table - Holidays and Special Events ...................................... 12

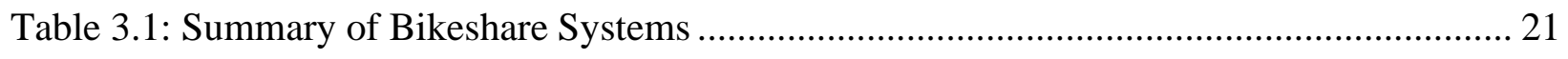

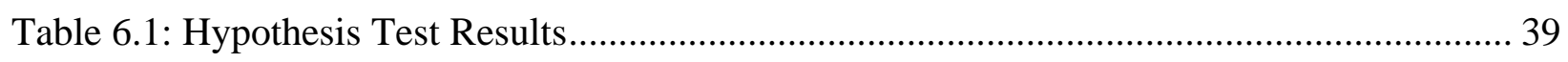

Table 7.1: Log-Linear Regression Model Results of Total Bikeshare Trips in Five Systems with Robust Standard Errors ............................................................................. 45

Table 7.2: Log-Linear Regression Model Results of Member Bikeshare Trips in Five Systems with Robust Standard Errors.......................................................................... 49

Table 7.3: Log-Linear Regression Model Results of Non-Member Bikeshare Trips in Five Systems with Robust Standard Errors ........................................................... 51

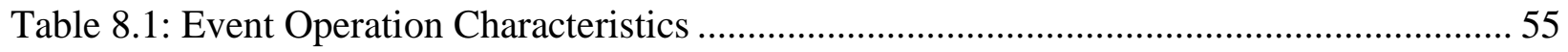

Table 8.2: Log-Linear Regression Model Results of Total Bikeshare Trips in Five Systems with Robust Standard Errors - Separate Model with Additional Special Event Indicator

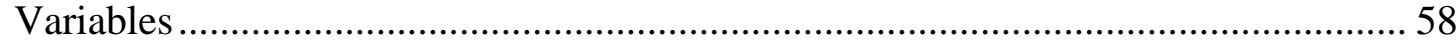

Table 8.3: Log-Linear Regression Model Results of Member Bikeshare Trips in Five Systems with Robust Standard Errors - Separate Model with Additional Special Event Indicator Variables.... 59

Table 8.4: Log-Linear Regression Model Results of Non-Member Bikeshare Trips in Five Systems with Robust Standard Errors - Separate Model with Additional Special Event Indicator Variables .............................................................. 60

Table C.1: Federal Holidays Grouped Plus Weekend Variable ........................................... 80

Table C.2: Federal Holidays Grouped and Saturday and Sunday Separately........................... 82

Table C.3: Non-Work Holidays Grouped by Business Closure Rate ...................................... 84

Table C.4: Holiday-Specific Effects with Additional Grouped by Saturday and Sunday Before Monday Federal Holidays 
Table C.5: Holiday-Specific Effects with Additional Individual Saturday and Sunday Before Monday Federal Holidays

Table C.6: Member Special Event Model.......................................................................... 93

Table D.1: Federal Holidays Grouped Plus Weekend Variable ............................................... 97

Table D.2: Federal Holidays Grouped and Saturday and Sunday Separately ........................... 99

Table D.3: Non-Work Holidays Grouped by Business Closure Rate...................................... 101

Table D.4: Holiday-Specific Effects with Additional Grouped by Saturday and Sunday Before Monday Federal Holidays........................................................................ 104

Table D.5: Holiday-Specific Effects with Additional Individual Saturday and Sunday Before Monday Federal Holidays..................................................................... 108

Table D.6: Non-Member Special Event Model ......................................................... 111 


\section{List of Figures}

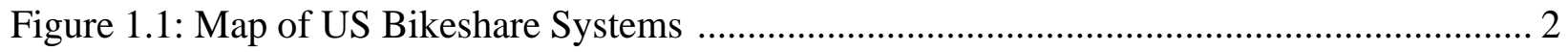

Figure 3.1: Divvy Year vs. Number of Trips................................................................... 20

Figure 3.2: Capital Bikeshare Calendar Heatmap for Non-Member Ridership - Log (Ratio of Daily Non-Member Ridership to 14 Day Moving Average NonMember Ridership) 23

Figure 4.1: Cherry Blossom Festival Corral Service - Capital Bikeshare .............................. 26

Figure 5.1: Conceptual Framework Diagram on Forming Hypotheses .................................. 28

Figure 6.1: Capital Bikeshare Member Model - Expected Ridership Ratio by Holiday ............. 34

Figure 6.2: Divvy Member Model - Expected Ridership Ratio by Holiday............................. 35

Figure 6.3: Bluebike Member Model - Expected Ridership Ratio by Holiday .......................... 35

Figure 6.4: Nice Ride Member Model - Expected Ridership Ratio by Holiday.......................... 36

Figure 6.5: Metro Bikeshare Member Model - Expected Ridership Ratio by Holiday ............... 36

Figure 9.1: Member Models - Expected Ridership Ratio by Different Separate Federal Holidays 65

Figure 9.2: Non-Member Models - Expected Ridership Ratio by Different Separate Federal Holidays 66

Figure A.1: 2017 Metro Bikeshare (Los Angeles) - Mean Number of Trips vs Time of Day, and Day of Week 73

Figure A.2: 2017 Bluebikes (Boston) - Mean Number of Trips vs Time of Day, and Day of Week 74

Figure A.3: 2017 Capital Bikeshare (Washington D.C.) - Mean Number of Trips vs Time of Day, and Day of Week 75 
Figure A.4: 2017 Capital Bikeshare (Washington D.C.) - Mean Number of Trips vs Time of Day, and Day of Week

Figure B.1: Nice Ride Calendar Heatmap for Total Ridership - Log (Ratio of Daily

Total Ridership to 14 Day Moving Average Total Ridership)..... 77

Figure B.2: Nice Ride Calendar Heatmap for Member Ridership - Log (Ratio of Daily Member Ridership to 14 Day Moving Average Member Ridership).

Figure B.3: Nice Ride Calendar Heatmap for Non-Member Ridership - Log (Ratio of Daily Non-Member Ridership to 14 Day Moving Average Non-Member Ridership) 78

Figure B.4: Bluebike Calendar Heatmap for Total Ridership - Log (Ratio of Daily Total Ridership to 14 Day Moving Average Total Ridership) 78

Figure B.5: Bluebike Calendar Heatmap for Member Ridership - Log (Ratio of Daily Member Ridership to 14 Day Moving Average Member Ridership) 79

Figure B.6: Bluebike Calendar Heatmap for Non-Member Ridership - Log (Ratio of Daily Non-Member Ridership to 14 Day Moving Average Member Ridership) 


\begin{abstract}
Bikeshare provides important first-mile last-mile, commuting, circulation, and sightseeing options in many cities. Bikeshare can also be healthy and convenient for users. Throughout the year, holidays occur which change typical bikeshare activity patterns. Existing literature shows mixed results relating to the ridership impacts of holidays, as some research shows that these days may result in higher ridership, while others show no effect. Because of variations in system locations and modeling methods, it is difficult to determine the reasons for these mixed results. To control for these aspects, this project consists of a multi-city study of the effect of holidays on system-level ridership using a log-linear regression model with robust standard errors. The results show the impacts of holidays on bikeshare system ridership for different user types among systems in the Washington D.C., Chicago, Boston, Los Angeles, and Minneapolis metro areas. Several hypotheses are built and tested for examining the expected effects of holidays on bikeshare usage. A major finding from this study is that federal holidays negatively affect bikeshare system subscribing member ridership and positively affect nonmember ridership. It was also found that different federal holidays have dissimilar effects on total ridership. For special events it was found that event operation characteristics impact special event bikeshare ridership. Park-based events had more positive effects on ridership than streetbased events, multi-day events generally showed increases in ridership compared to single day events, and national events contributed to the highest bikeshare ridership. These findings could be useful for states, counties, cities, parks, recreation facilities and bikeshare agencies to plan, reposition fleets, and improve system operation. Lastly, these findings could be useful to urban
\end{abstract}


planners and civic leaders in the consideration of road closures and other traffic changes to ensure pedestrian safety on these special days. 


\section{Chapter 1: Introduction ${ }^{1}$}

\subsection{Background}

Bikeshare provides important first-mile last-mile, commuting, circulation, and sightseeing options in many cities. Bikeshare can be healthy and convenient for users, can support use of public transportation, reduce energy consumption and emissions, save space in urban cores, and can even be fun.

\subsubsection{What is Bikeshare?}

Bikesharing is a transportation system that allows the public to swiftly and opportunely rent a bicycle for short distance trips. As of 2018, there were 67 U.S. cities with bikeshare systems logging 45.5 million bikeshare trips - $80 \%$ of these trips were station based and $20 \%$ were freely floating. Station-based bikeshare is when bikes can be picked up from a bikeshare station and dropped off at any other bikeshare station in the network. Free-floating bikeshare on the other hand is when bikes can be locked to an ordinary bicycle rack or any other solid frame or standalone, eliminating the need for specific bikeshare stations (Pal and Zhang, 2017). In the U.S. in 2018 there were a total of 57,000 station-based bikes available (National Association of City Transportation Officials, 2018). Bikeshare ridership includes both leisure and work-related trips. It is important and useful to gain insights into how and why travelers choose bikesharethis is valuable for planning and for network design and operations (e.g. for pre- and repositioning of the bikes). There is substantial research on characteristics of bikeshare commute

\footnotetext{
${ }^{1}$ Material in this chapter has been submitted to the Transportation Research Board for possible publication.
} 
trips, but there is limited research on leisure-based trips during weekends, holidays and special events. During a typical year there are 10 federal holidays, accounting for $3 \%$ of all calendar days. For example, in 2018 in Washington, D.C.'s Capital Bikeshare system there are approximately 68,000 trips taken during federal holidays that account for about $2 \%$ of all trips. These types of days are interesting for analysis because they are when users characteristically change their daily routines and alter their typical travel/bikeshare behavior.

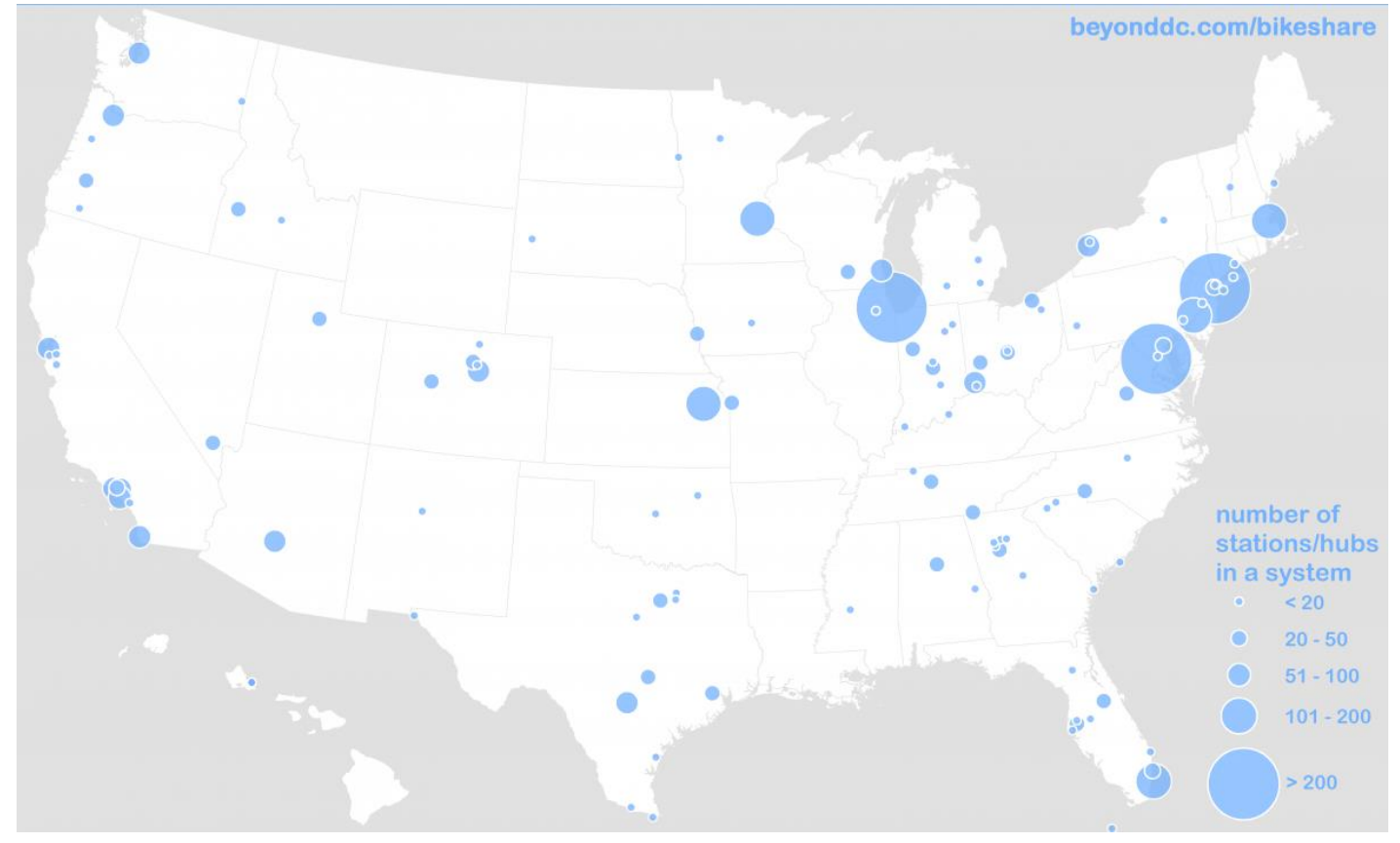

Figure 1.1: Map of US Bikeshare Systems (Public Domain from https://ggwash.org/view/62137/all-119-us-bikeshare-systems-ranked-by-size , 2017)

\subsubsection{Who uses Bikeshare?}

There are two different pass options for using the bikeshare system - member passholders and non-member passholders. These passes can be purchased at any station with a kiosk, phone application or online. To become a member, thirty-day passes, or annual passes are available. For non-members, twenty-four-hour passes, or three-day passes are available. Xiaolu Zhou (2015) stated that subscriber users were more commute oriented and customer users were more recreational oriented. This thesis assumes members use the bikeshare system for 
commuting and non-member for leisure related trips. This thesis also uses trips and ridership interchangeably throughout the paper.

\subsection{Motivation}

Past investigations of the impacts of holidays on bikeshare usage show varying results due to differences in holiday definitions, user composition across systems, and modeling specifications. Past studies found a range of directional effects of combined weekend and holiday indicator variables including increased (El-Assi et al., 2020; Corcoran et al., 2014) and decreased ridership (Mattson and Godavarthy, 2017; Sun et al., 2018; Gebhart and Noland, 2014). Although research has found that bikeshare system subscribing members and non-members exhibit different bikeshare usage behavior (Sun et al., 2018; Wang and Lindsey, 2019; Zhou, 2015), no studies have analyzed holiday impact by user type. Similarly, few studies have analyzed system-level ridership patterns during special events. This study identifies the following five gaps in understanding bikeshare usage behavior during holidays and special events:

- Comparing results across studies is difficult due to varying holiday classifications. Different scales of holidays, including federal holidays (Gebhart and Noland, 2014), public holidays (Corcoran et al., 2014; Kim, 2018), school holidays (Corcoran et al., 2014; Mattson and Godavarthy, 2017; Kim, 2018), and local holidays (Kaltenbrunner et al., 2010) have different effects on bikeshare usage resulting in incomparable results.

- Existing studies do not account for user heterogeneity in system-level ridership patterns on holidays. Members and non-members have different usage profiles, which 
may lead to different holiday ridership. Focusing only on total ridership obscures this possible relationship.

- Are there differences between holidays and weekend ridership patterns? Federal holidays and weekends share some similar effects due to them both being nonworkdays. It was found that no past studies have clearly answered this question.

- Are there differences in ridership patterns between individual holidays? Holiday traditions have differing social and recreational activity spaces and preference profiles. No previous research on daily bikeshare ridership has analyzed the effects of holidays individually.

- Few studies consider analyzing system-level ridership patterns during special events. Special events may attract bikeshare users, depending on proximity to bikeshare stations or zones, level of outdoor involvement, the size of the event space/area, weather, event time span and the distribution of attendees' time use. There were only two studies that incorporated limited special events in their analysis (Younes et al., 2020; Kaltenbrunner et al., 2010).

Filling in these gaps are the premise of this thesis and the motivation behind understanding system level bikeshare ridership during holidays and special events across multiple cities.

\subsection{Objective}

The objectives of this thesis are as follows:

- To infer the impacts of holidays on bikeshare system-level ridership; and

- To explore the impacts of special events on bikeshare system-level ridership. 
To achieve this, this thesis conducts a multi-city and multi-year investigation of the effects of holidays and special events on system-level bikeshare ridership in five U.S. cities using a log-linear regression with robust standard errors model. Repeating the experiment over multiple occasions and years across five different bikeshare systems increases the robustness of the study for making inferences and strengthening the hypotheses. None of the past studies had more than two years of data, which makes the inference of separate holiday effects difficult since there is limited or no replication of individual holidays in the analysis. This along with estimating holidays and weekends as one indicator variable could lead to the misinterpretation of the influence of special calendar days on bikeshare ridership.

\subsection{Findings}

To better understand the five research gaps presented in section 1.2, this study analyzes daily ridership patterns across bikeshare systems in Washington D.C., Chicago, Boston, Minneapolis, and Los Angeles. The contributions to each gap are summarized as follows:

- Comparing results across studies is difficult due to varying holiday classifications. To address the first gap, this study defines holidays as federal and non-work holidays across five systems. By conducting a multi-city analysis with clearly defined and consistent holidays, general ridership patterns on the same types of holidays can be drawn from the results.

- Existing studies neglect to account for user heterogeneity in system-level ridership patterns on holidays. For the second gap, to address all user types, the effects of holidays on bikeshare system subscribing member and non-member ridership are considered separately rather than addressing only total ridership. This could explain some characteristics of different types of bikeshare system users on holidays. 
- Are there differences between holiday and weekend ridership patterns? To understand gap three, this study found support that ridership behavior indeed varies between holidays and weekends.

- Are there differences in ridership patterns between individual holidays? For gap four, this study found differences between different holiday ridership patterns. For example, Thanksgiving and Christmas result in less total ridership than Labor Day and Memorial Day.

- Few studies consider analyzing system-level ridership patterns during special events. To understand gap five, this study found differences in special event types based on operational characteristic classifications. Park-based events had more positive effects on ridership than street-based events, multi-day events generally showed increase in ridership compared to single day events, and national events contributed to the highest bikeshare use.

\subsection{Organization of the Thesis}

The remainder of this thesis is organized as follows: Chapter 2 provides a literature review concerning the research question: Why does existing literature have disparities amongst different bikeshare system-level ridership results on holidays? The literature review is broken down into three sections: a holiday literature review, a special event literature review, and a multi-city analysis literature review. The holiday literature review is split by variable specification: weekend and weekday indicator variables only; inclusion of membership type; combined weekend and holiday indicator variables; grouped holidays into binary variables separate from the weekend variable; and special event indicator variables. The multi-city analysis literature review is split by the number of cities defined in the studies' analysis. Chapter 
3 describes the bikeshare data obtained from the respective bikeshare systems, and weather data obtained from Weather Underground and the National Oceanic and Atmospheric Administration (NOAA). Chapter 4 describes the methodology and model specification. Chapter 5 explains the hypotheses that were tested based on grouped non-work holiday effects, holiday-specific effects, and Cherry Blossom Festival Effects. Chapter 6 pertains to the analyses of the hypotheses using different tests (one-sided and two-sided $t$-tests, likelihood ratio test). Chapter 7 provides the results of the individual holiday effects models using log-linear regression models with robust standard errors. Chapter 8 provides the special event model descriptions and their Federal Highway Administration (FHWA) event operation characteristics. Lastly, Chapter 9 briefly discusses conclusions drawn and future recommendations for research. 


\section{Chapter 2: Literature Review ${ }^{2}$}

This chapter explores existing literature that focuses on bikeshare ridership on special calendar days. The literature review is split into three sections: holidays, special events, and a multi-city investigation. The holiday literature review will explore the modeling specifications used to define and incorporate holidays into each analysis and their respective directional effects. The special event literature review will explore studies that incorporated special event indicator variables into the econometric models to account for special calendar days. Lastly, the multi-city investigation will explore whether the size of the bikeshare system along with the number of bikeshare systems analyzed are comparable so that testing methods can be transferable to other cities.

\subsection{Holiday Literature Review}

In past investigations of bikeshare use in the U.S. and abroad, there have been some disparities in findings regarding holiday bikeshare use across different systems. Holidays occur on weekdays and weekends, but the approach as to how to define them in econometric models differs amongst studies.

Some prior bikeshare studies have distinguished between weekend and weekday variables in their models to account for calendar days. In Montreal, for example, Faghih-Imani et al. (2014) found that weekends had a negative effect on arrival and departure rates, along with Zhou (2015) who found that weekend ridership was much lower than weekday ridership in

\footnotetext{
2 "Material in this chapter has been submitted to [Transportation Research Board] and to [Journal of Big Data Analytics] for possible publication."
} 
Chicago. Conversely, Hyland et al. (2018) found that both weekends and weekdays had positive effects on total trip counts in Chicago. In Washington D.C., Younes et al. (2020) incorporated separate day of the week fixed effects. Relative to Sunday, their models revealed that Monday had fewer trips; Tuesday through Thursday had similar trips; and Friday and Saturday had more trips. Further, a study discovered that Friday evening trip counts were like Saturday counts, which indicates that Friday evenings are similar to weekend days, and therefore Fridays can exhibit ridership patterns like a weekday and a weekend day in different cities (Faghih-Imani et al., 2014).

Whether the user is a subscribing member or non-member of the bikeshare system can also impact the ridership results on different calendar days. Typically, bikeshare members have annual or monthly passes while non-members have single day passes. Wang et al. (2019) found that annual members took fewer bikeshare trips on weekends in St. Paul, Minnesota. Likewise, Sun et al. (2018) found that on weekends in Seattle, member ridership declined while nonmember ridership increased. Zhou (2015) observed that member users were more commuteoriented and non-member users were more recreationally oriented. This could explain why past analyses found weekend ridership to be lower for members who were not working/commuting and higher for casual non-members since special events and leisure may attract local residents and tourists to bikeshare on weekends. Analyzing trips made by members and non-members separately can provide more information in a model on the types of riders utilizing the system on different calendar days.

A limitation in the above studies is that they did not include holiday indicator variables in their econometric models. For example, missing holiday variables could result in omitted variable bias and unobserved heterogeneity issues, as not incorporating any form of a holiday 
variable could make it unclear whether the magnitude and direction of the weekend and weekday parameter estimates are caused by the weekend and weekday itself or caused by the unobserved effects of the holidays.

There is limited consensus, however, on how to incorporate holidays in the analysis of calendar day effects. This occurs across two factors:

- What is defined as a holiday?

- How are holidays incorporated into the model?

Across the studies reviewed, the definition of a holiday varies. Cultural differences can play a role in the definition of holidays. Across studies internationally, Kim (2018) in Daejeon, South Korea and Corcoran et al. (2014) in Brisbane, Australia studied public and school holidays, Kaltenbrunner et al. (2010) in Barcelona included local holidays, El-Assi et al. (2020) in Toronto statutory holidays and Zhang et al. (2017) in Zhongshan, China undefined holidays. Undefined holidays are when studies use a holiday variable in the analysis, but do not specify what holidays are being analyzed. Across studies in the U.S. alone, one used school holidays in Fargo, North Dakota (Mattson and Godavarthy, 2017), one used national holidays (Sun et al., 2018), one used federal holidays in Washington D.C. (Gebhart and Noland, 2014), and two used undefined holidays (Wang et al., 2019; Younes et al., 2020).

Past studies found a range of directional effects of the combined weekend and holiday indicator variables. To account for unobserved heterogeneity due to holidays, a common approach is to combine holidays with weekends into a single fixed effect. Across models with weekend-holiday fixed effects, decreased bikeshare ridership was observed for school holidays (Mattson and Godavarthy, 2017), national holidays (Sun et al., 2018), and federal holidays (Gebhart and Noland, 2014). In one study, increased ridership occurred on statutory holidays (El- 
Assi et al., 2020). Corcoran et al. (2014) also found that weather (ambient temperature) was associated with increased ridership on public holidays and weekends as compared to weekdays. Using shared variables in a model indicates that the modeler assumes the effects of weekends and holidays are mutual.

To distinguish between weekends and holidays, some studies grouped holidays into a binary variable separate from the weekend variable. Kim (2018) found that public holidays had a negative effect on system-hour-daily ridership, but Corcoran et al. (2014) found that public holidays wielded a positive effect on total system ridership. A commonality in the literature is that school holidays exerted no significance on ridership; this is often attributed to age restrictions on bikeshare membership (Corcoran et al., 2014; Kim, 2018). Younes et al. (2020) and Zhang et al. (2017) included a general holiday indicator variable. Both found that holidays induced no effect on both member and non-member trips.

Holiday impact on ridership appears to change based on how holidays are classified and grouped. While separating the holiday and weekend indicator variables may strengthen the results, failure to ungroup the holidays based on the holiday (Christmas, Veterans Day, Labor Day, etc.) could mask the actual effects of each individual day. There is a lack of research regarding ungrouping holidays, but it may not always be feasible in some analyses due to the time frame of the study. For example, Zhang et al. (2017) had a grouped holiday variable in their model, but the study only occurred over a four-month period. None of the studies reviewed had more than two years of data, which makes the inference of separate holiday effects difficult since there is limited or no replication of individual holidays in the analysis. 


\subsection{Special Event Literature Review}

As these studies evaluated the factors that influenced bikeshare ridership that change based on weekdays, weekends, and holidays, very few studies incorporate special events in their model local to the bikeshare system analyzed. In Washington D.C., Younes et al. (2020) found that the annual Cherry Blossom Festival had a substantial positive impact on all trips. Many customers utilized the bikeshare system to participate in the activities at the Cherry Blossom Festival. Kaltenbrunner et al. (2010) found that on a local holiday, the Feast of Sant Joan, Barcelona's bikeshare system exhibited ridership patterns more like a typical Sunday although the holiday occurred on a Tuesday that year. Therefore, different holidays and special events may cause changes in bikeshare decision making. Table 2.1 summarizes the holiday and special event variables from the literature review in a table with the corresponding directional effects.

Table 2.1: Literature Review Table - Holidays and Special Events

\begin{tabular}{|l|l|l|l|l|l|l|}
\hline Author & Model & Location & $\begin{array}{c}\text { Time } \\
\text { Period }\end{array}$ & $\begin{array}{l}\text { Dependent } \\
\text { Variable }\end{array}$ & $\begin{array}{l}\text { Independent } \\
\text { Variable } \\
\text { (relevant to } \\
\text { this study) }\end{array}$ & $\begin{array}{l}\text { Directional } \\
\text { Effect }\end{array}$ \\
\hline $\begin{array}{l}\text { Corcoran } \\
\text { et al. }\end{array}$ & $\begin{array}{l}\text { Poisson } \\
\text { Regression } \\
\text { Model }\end{array}$ & $\begin{array}{l}\text { Brisbane, } \\
\text { Australia }\end{array}$ & $\begin{array}{l}\text { Nov. } \\
2010 \text { to } \\
\text { Jul. } \\
2012\end{array}$ & $\begin{array}{l}\text { Total Trips } \\
\text { (log) }\end{array}$ & $\begin{array}{l}\text { Public Holiday, } \\
\text { School } \\
\text { Holiday, } \\
\text { Weekend }\end{array}$ & $\begin{array}{l}\text { No effect on } \\
\text { public or } \\
\text { school } \\
\text { holidays }\end{array}$ \\
\hline $\begin{array}{l}\text { El-Assi } \\
\text { et al. }\end{array}$ & $\begin{array}{l}\text { Weekday } \\
\text { and/Weekend } \\
\text { Distributed Lag } \\
\text { Model; } \\
\text { Multi-Level } \\
\text { Mixed-Effects } \\
\text { Regression } \\
\text { Model }\end{array}$ & $\begin{array}{l}\text { Toronto, } \\
\text { Canada }\end{array}$ & 2013 & $\begin{array}{l}\text { Natural } \\
\text { Logarithm of } \\
\text { the Trip } \\
\text { Counts }\end{array}$ & $\begin{array}{l}\text { Statutory } \\
\text { Holidays and } \\
\text { Weekends, } \\
\text { Weekday }\end{array}$ & $\begin{array}{l}\text { Increased } \\
\text { ridership } \\
\text { occurred on } \\
\text { statutory } \\
\text { holidays }\end{array}$ \\
\hline
\end{tabular}


Table 2.1 (Continued)

\begin{tabular}{|c|c|c|c|c|c|c|}
\hline $\begin{array}{l}\text { Faghih-Imani } \\
\text { et al. }\end{array}$ & $\begin{array}{l}\text { Multilevel } \\
\text { Linear } \\
\text { Mixed } \\
\text { Model }\end{array}$ & \begin{tabular}{|l} 
Montreal, \\
Canada
\end{tabular} & $\begin{array}{l}\text { Apr. to Aug. } \\
2012\end{array}$ & $\begin{array}{l}\text { Arrivals or } \\
\text { Departures } \\
\text { at a Station }\end{array}$ & \begin{tabular}{|l} 
Weekends, \\
Weekdays, \\
Friday and \\
Saturday \\
Nights
\end{tabular} & \begin{tabular}{|l} 
Bicycle \\
usage \\
decreased \\
during \\
weekends in \\
Montreal, \\
but \\
increased on \\
Friday and \\
Saturday \\
Nights
\end{tabular} \\
\hline $\begin{array}{l}\text { Gebhart and } \\
\text { Noland }\end{array}$ & $\begin{array}{l}\text { Negative } \\
\text { Binomial } \\
\text { Model }\end{array}$ & $\begin{array}{l}\text { Washington } \\
\text { D.C. }\end{array}$ & $\begin{array}{l}\text { Oct. } 1,2010 \\
\text { to Dec. 31, } \\
2011\end{array}$ & $\begin{array}{l}\text { Trips per } \\
\text { Hour }\end{array}$ & $\begin{array}{l}\text { Weekends } \\
\text { and Federal } \\
\text { Holidays, } \\
\text { Month } \\
\text { Year }\end{array}$ & $\begin{array}{l}\text { Usage on } \\
\text { weekends } \\
\text { and } \\
\text { holidays is } \\
\text { not } \\
\text { significantly } \\
\text { different } \\
\text { than on } \\
\text { weekdays }\end{array}$ \\
\hline Hyland et al. & $\begin{array}{l}\text { Multilevel } \\
\text { Mixed- } \\
\text { Effect } \\
\text { Regression } \\
\text { Model- } \\
\text { Hybrid } \\
\text { Cluster- } \\
\text { Regression } \\
\text { Approach }\end{array}$ & $\begin{array}{l}\text { Chicago, } \\
\text { Illinois }\end{array}$ & 2016 & $\begin{array}{l}\text { Log (Trip } \\
\text { Count) }\end{array}$ & $\begin{array}{l}\text { Dec. 2016, } \\
\text { Weekdays } \\
\text { in Month, } \\
\text { Weekend } \\
\text { Days in } \\
\text { Month, } \\
\text { Month }\end{array}$ & $\begin{array}{l}\text { Weekends } \\
\text { and } \\
\text { weekdays } \\
\text { had positive } \\
\text { effects on } \\
\text { total trip } \\
\text { counts in } \\
\text { Chicago }\end{array}$ \\
\hline \begin{tabular}{|l} 
Jeremy \\
Mattson and \\
Ranjit \\
Godavarthy
\end{tabular} & $\begin{array}{l}\text { Regression } \\
\text { Model }\end{array}$ & $\begin{array}{l}\text { Fargo, } \\
\text { North } \\
\text { Dakota }\end{array}$ & $\begin{array}{l}2015 \text { and } \\
2016\end{array}$ & $\begin{array}{l}\text { Ridership } \\
(\log )\end{array}$ & $\begin{array}{l}\text { Weekend } \\
\text { or Holiday, } \\
\text { Year }\end{array}$ & $\begin{array}{l}\text { Negative } \\
\text { effect for } \\
\text { weekend or } \\
\text { holidays }\end{array}$ \\
\hline $\begin{array}{l}\text { Kaltenbrunner } \\
\text { et al. }\end{array}$ & $\begin{array}{l}\text { Auto- } \\
\text { Regressive } \\
\text { Moving } \\
\text { Average } \\
\text { (ARMA) } \\
\text { Model }\end{array}$ & $\begin{array}{l}\text { Barcelona, } \\
\text { Spain }\end{array}$ & $\begin{array}{l}\text { May } 15, \\
2008 \text { to Jul. } \\
3,2008\end{array}$ & $\begin{array}{l}\text { Number of } \\
\text { Bicycles } \\
\text { Available }\end{array}$ & $\begin{array}{l}\text { Time of } \\
\text { Day, Day } \\
\text { of Week, } \\
\text { Local } \\
\text { Holiday }\end{array}$ & $\begin{array}{l}\text { Feast of } \\
\text { Sant Joan } \\
\text { has bicycle } \\
\text { patterns } \\
\text { more like a } \\
\text { typical } \\
\text { Sunday } \\
\end{array}$ \\
\hline
\end{tabular}


Table 2.1 (Continued)

\begin{tabular}{|c|c|c|c|c|c|c|}
\hline $\begin{array}{l}\text { Kyoungok } \\
\text { Kim }\end{array}$ & $\begin{array}{l}\text { Negative } \\
\text { Binomial } \\
\text { Regression } \\
\text { Model }\end{array}$ & $\begin{array}{l}\text { Daejeon, } \\
\text { South Korea }\end{array}$ & 2015 & $\begin{array}{l}\text { Number of } \\
\text { Bicycle } \\
\text { Rentals }\end{array}$ & $\begin{array}{l}\text { Weekend, } \\
\text { Public } \\
\text { Holidays, } \\
\text { School } \\
\text { Holidays }\end{array}$ & $\begin{array}{l}\text { Negative } \\
\text { effect on } \\
\text { public } \\
\text { holidays; } \\
\text { School } \\
\text { holidays } \\
\text { do not } \\
\text { have a } \\
\text { significant } \\
\text { impact on } \\
\text { bikeshare } \\
\text { usage }\end{array}$ \\
\hline Sun et al. & $\begin{array}{l}\text { Generalized } \\
\text { Additive } \\
\text { Mixed } \\
\text { Model } \\
\text { (GAMM) }\end{array}$ & $\begin{array}{l}\text { Seattle, } \\
\text { Washington }\end{array}$ & $\begin{array}{l}\text { Oct. } \\
15, \\
2014 \text { to } \\
\text { Aug. } \\
31, \\
2016\end{array}$ & $\begin{array}{l}\text { Total } \\
\text { Counts of } \\
\text { Pickups } \\
\text { and } \\
\text { Returns }\end{array}$ & $\begin{array}{l}\text { Workday, } \\
\text { National } \\
\text { Holiday and } \\
\text { Weekend }\end{array}$ & $\begin{array}{l}\text { Non- } \\
\text { working } \\
\text { days are } \\
\text { negatively } \\
\text { correlated } \\
\text { with } \\
\text { member } \\
\text { pickups } \\
\text { but } \\
\text { positively } \\
\text { correlated } \\
\text { with } \\
\text { short-term } \\
\text { pass } \\
\text { holder } \\
\text { pickups }\end{array}$ \\
\hline Wang et al. & $\begin{array}{l}\text { Linear } \\
\text { Mixed- } \\
\text { Effects } \\
\text { Models and } \\
\text { Multinomial } \\
\text { Logistic } \\
\text { Models }\end{array}$ & $\begin{array}{l}\text { Minneapolis- } \\
\text { St. Paul, } \\
\text { Minnesota }\end{array}$ & 2017 & $\begin{array}{l}\text { Average } \\
\text { Daily Trip } \\
\text { Frequency, } \\
\text { Average } \\
\text { Daily Trip } \\
\text { Frequency } \\
\text { on } \\
\text { Weekends, } \\
\text { Average } \\
\text { Daily Trip } \\
\text { Frequency } \\
\text { on } \\
\text { Weekdays }\end{array}$ & $\begin{array}{l}\text { Weekends } \\
\text { and Holidays }\end{array}$ & $\begin{array}{l}\text { Annual } \\
\text { members } \\
\text { took } \\
\text { fewer } \\
\text { bikeshare } \\
\text { trips on } \\
\text { weekends } \\
\text { in St. } \\
\text { Paul, } \\
\text { Minnesota }\end{array}$ \\
\hline
\end{tabular}


Table 2.1 (Continued)

\begin{tabular}{|c|c|c|c|c|c|c|}
\hline $\begin{array}{l}\text { Xiaoula } \\
\text { Zhou }\end{array}$ & $\begin{array}{l}\text { Hierarchical } \\
\text { Clustering } \\
\text { Method }\end{array}$ & $\begin{array}{l}\text { Chicago, } \\
\text { Illinois }\end{array}$ & $\begin{array}{l}\text { Jul. to } \\
\text { Dec. } \\
2013 \text {; } \\
\text { Jul. to } \\
\text { Dec. } \\
2014\end{array}$ & $\begin{array}{l}\text { Total } \\
\text { Over- } \\
\text { Demand } \\
\text { Numbers } \\
\text { for Docks } \\
\text { and Bikes }\end{array}$ & $\begin{array}{l}\text { Time of Day, } \\
\text { Day of Week, } \\
\text { Subscribers vs. } \\
\text { Customers }\end{array}$ & $\begin{array}{l}\text { Weekend } \\
\text { usage was } \\
\text { much less } \\
\text { than on } \\
\text { weekdays }\end{array}$ \\
\hline $\begin{array}{l}\text { Younes } \\
\text { et al. }\end{array}$ & $\begin{array}{l}\text { Negative } \\
\text { Binomial } \\
\text { Regression, } \\
\text { Log-Linear } \\
\text { OLS } \\
\text { Regression }\end{array}$ & $\begin{array}{l}\text { Washington, } \\
\text { D.C. }\end{array}$ & $\begin{array}{l}\text { Dec. } \\
2018 \text { to } \\
\text { Jun. } \\
2019\end{array}$ & $\begin{array}{l}\text { Number of } \\
\text { Trips per } \\
\text { Hour, } \\
\text { Medium } \\
\text { Duration } \\
\text { of Trips } \\
\text { per Hour }\end{array}$ & $\begin{array}{l}\text { Cherry } \\
\text { Blossom } \\
\text { Festival, } \\
\text { Government } \\
\text { Shutdown, } \\
\text { Day of Week }\end{array}$ & $\begin{array}{l}\text { Holidays } \\
\text { had a } \\
\text { positive } \\
\text { effect on } \\
\text { casual } \\
\text { bikeshare } \\
\text { trips and } \\
\text { fewer } \\
\text { member } \\
\text { trips; } \\
\text { The } \\
\text { Cherry } \\
\text { Blossom } \\
\text { Festival } \\
\text { had a } \\
\text { significant } \\
\text { positive } \\
\text { impact on } \\
\text { all types } \\
\text { of bike } \\
\text { share trip } \\
\text { activities }\end{array}$ \\
\hline $\begin{array}{l}\text { Zhang et } \\
\text { al. }\end{array}$ & $\begin{array}{l}\text { Multiple } \\
\text { Linear } \\
\text { Regression } \\
\text { Models }\end{array}$ & $\begin{array}{l}\text { Zhongshan, } \\
\text { China }\end{array}$ & $\begin{array}{l}\text { Feb. to } \\
\text { Jun. } \\
2014\end{array}$ & $\begin{array}{l}\operatorname{Ln}[\mathrm{D} / \mathrm{S}] \text { of } \\
\text { Weekdays, } \\
\text { Weekends, } \\
\text { and } \\
\text { Holidays }\end{array}$ & $\begin{array}{l}\text { Weekdays, } \\
\text { Weekends and } \\
\text { Holidays }\end{array}$ & $\begin{array}{l}\text { Negative } \\
\text { impact on } \\
\text { daily D/S } \\
\text { at stations } \\
\text { on } \\
\text { weekdays } \\
\text { and no } \\
\text { influence } \\
\text { on } \\
\text { weekends } \\
\text { and } \\
\text { holidays }\end{array}$ \\
\hline
\end{tabular}




\subsection{Multi-City Analysis Literature Review}

There is a growing literature analyzing bikeshare usage, where most research that considers an array of trip factors, only discusses a single bikeshare system. Bikeshare trips in Washington, D.C. were analyzed using a negative binomial model. Using hourly weather data, the influence of temperature, rainfall, snow, wind, fog, and humidity were examined. Results showed that the number of trips significantly increased for temperatures in the 90-degree $\mathrm{F}$ range, as compared to the 50-degree $\mathrm{F}$ range. They also found that a combined weekend and federal holiday indicator variable decreased total ridership (Gebhart and Noland, 2014). The influence of weather, temporal characteristics, bicycle infrastructure, land use, and the built environment was studied in an analysis of Montreal's bicycle-sharing system using a multi-level linear mixed model. Hourly station-level arrival and departure rates were examined, and a positive correlation was found between temperature and bikeshare usage. Humidity negatively impacted usage, and rainy weather negatively impacted departure rates. Lastly, they found that weekends had a negative effect on arrival and departure rates; along with Friday evening trip counts behaving like Saturday trip counts (Faghih-Imani et al. 2014). Their findings were similar to the other studies of single bikeshare systems (Gebhart and Noland, 2014; Mattson and Godavarthy, 2017; Caulfield et al., 2017). Although these variables were considered to analyze ridership trends, they did not test or compare the bikeshare system with other bikeshare systems. It can be important to compare other bikeshare systems in order to expand the network to other cities.

Some prior research has analyzed single bikeshare systems but explained that the reasoning for their trends were due to the size of the system. For example, an analysis of the Fargo, North Dakota Great Ride Bike-Share System estimated ridership as a function of weather, 
temporal, and spatial variables. Results showed negative impacts of both cold and hot weather, precipitation, and wind on bikeshare ridership. The results confirmed that temperature had a quadratic relationship with ridership. Ridership decreased over 81 degrees F. Also, in colder temperatures, for example, if the temperature is 30 degrees $\mathrm{F}$, a one-degree increase in temperature would increase ridership by 5.4\%. Combined weekend and school holiday indicator variables displayed a negative effect on ridership. Also, the presence of stations on the local university campus was found to have a significant positive impact on ridership. Researchers believed that the small number of stations in Fargo made it difficult to estimate the impact of ridership based on explanatory factors (Mattson and Godavarthy, 2017). A 2011 examination of ridership patterns of the Cork, Ireland bikeshare system (medium-sized city with a small bikeshare system) found that most trips were short, but frequent, which suggests the incorporation of bikeshare ridership into users' daily (or weekly) trips. Researchers also found that weather impacted ridership, with longer trip durations occurring during ideal weather conditions (Caulfield et al., 2017). The findings provide insight to the dynamics of ridership in a smaller sized bikeshare system network. Although an in-depth comparative analysis wasn't conducted, it still provides insight for future planning.

A comparative analysis on 25 U.S. university campuses was conducted in 17 cities. Researchers evaluated the influence of campus characteristics, temporal factors, and weather events on daily bikeshare trips from 2014-2018. Only trips that began and ended at campus stations were considered. They found that weekends, holidays, term breaks, and summer terms were associated with fewer trips per day. During the fall term, however, there was a larger number of trips per day due to the students attending class. Also, as expected, severe weather events resulted in fewer trips, and days with a higher mean temperature yielded more trips. Also, 
in the presence of visibility-related adverse weather, such as fog, smoke, or mist, the observed number of daily trips were approximately 0.25 percent fewer than when the weather was clear. The results of the study show that the measures are transferable to other campuses as many U.S. college campuses have similar characteristics to those in the study sample (Kutela and Teng, 2019). While the study included a comparative analysis of bikeshare systems across college campuses, it did not analyze patterns across the cities as a whole. Ridership may be different on college campuses as colleges have a younger, usually healthier demographic with lower incomes and different travel patterns and trip making characteristics that influence their travel behavior.

A comparative assessment among public bikeshare systems consisted of creating a database of 50-100 systems with 8 main aspects and 100 parameters (Matrai and Toth, 2016). The authors state, "the lack of comprehensive database about public bikeshare systems in the world does not allow comparing or evaluating them. A guideline does not exist to help planners, experts or decision makers to create a new system or amend an existing one." Although this would be beneficial, there is no comprehensive, worldwide comparative evaluation of the public bikeshare systems. Data are not necessarily available for every scenario, and the authors stressed the importance of performing a comparative analysis, along with the drawbacks and successes of their model. 


\section{Chapter 3: Data Description ${ }^{3}$}

Five station-based bikeshare systems were selected as case studies in this analysis: Capital Bikeshare (Washington, D.C.), Bluebike (Boston), Divvy (Chicago), Nice Ride (Minneapolis) and Metro Bikeshare (Los Angeles). In 2018, these systems accounted for approximately 13,800 station-based bikes (nearly $24 \%$ of the total in the U.S.) and 9.5 million total trips (nearly $26 \%$ of the total in U.S.) (National Association of City Transportation Officials, 2018). To maintain consistency in the estimation results, the first three systems were selected because of their similarities in system size and weather characteristics. Looking at Nice Ride (Minneapolis) and Metro Bikeshare (Los Angeles) with unique characteristics may enhance the analysis as it can see whether system disparities affect holiday ridership. Nice Ride (Minneapolis) is somewhat unique as it closes its operations in the winter, so it does not account for the winter holidays in Minneapolis. Also, member and non-member trips have an almost even distribution in ridership, while members dominate bikeshare culture in the other studied systems. To control for possible seasonal variations in the outdoor leisure activity space, Metro Bikeshare (Los Angeles) was included due to its subtropical climate to increase the robustness of the hypothesis testing for the holiday-specific effects.

Daily ridership data was compiled for each system using disaggregate trip data accessed via each system's respective websites (Capital Bikeshare, 2020; Bluebikes, 2020; Divvy, 2020; Nice Ride, 2020; NOAA, 2020). The individual trip information from each system included: start

\footnotetext{
${ }^{3}$ Material in this chapter has been submitted to the Transportation Research Board for possible publication.
} 
and end time, origin and destination station, and user type (member or non-member). Depending on system inception dates, the systems were analyzed over different time periods. Additionally, the data at the beginning of each system will be excluded in this study to avoid instability of the systems during their growing phases. For example, for Divvy in Chicago, the startup years of the bikeshare system were removed. Removing these years makes comparing annual ridership easier as years before 2015 show much less ridership. When modeling, estimation results are intended for an established bikeshare system, therefore considering the startup period of a bikeshare system can skew model results.

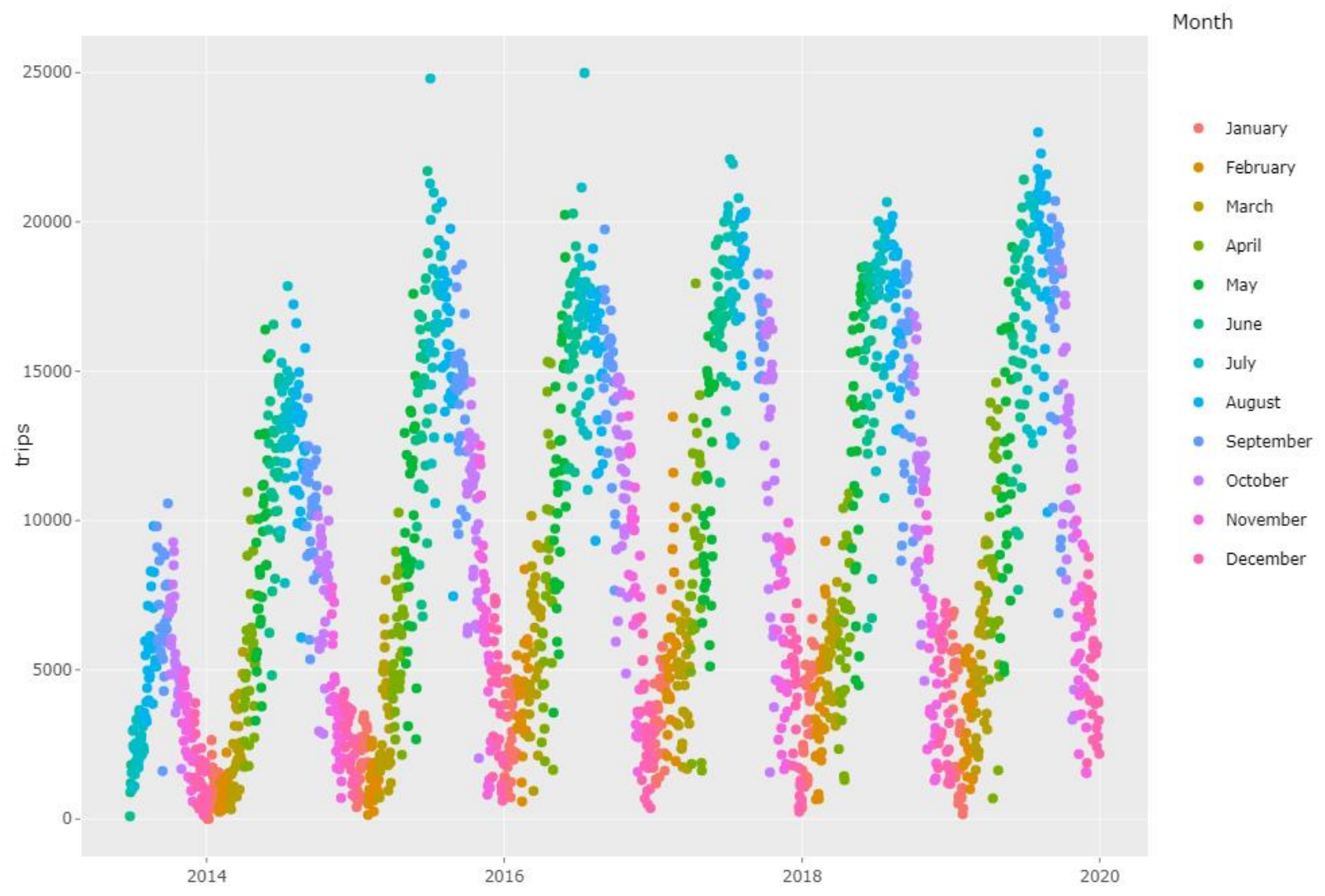

Figure 3.1: Divvy Year vs. Number of Trips 
Furthermore, the data cleaning effort involved removing data from trips with unknown user types. The cleaned data for each system are listed below.

- Capital Bikeshare: Excluded 2011 data.

- Divvy: Excluded 2013 and 2014 data.

- Bluebike: Excluded data from the first four months of 2015.

- Nice Ride: Excluded data from 2010 and 2011.

- Metro Bikeshare: Excluded data from the first four months of operation in 2017 to avoid initial instability.

- Excluded observations with unknown user types. About $1 \%$ of the data was removed from Bluebike, 4\% Capital Bikeshare, 5\% Metro Bikeshare, 8\% Divvy, and 10\% Nice Ride.

Table 3.1 presents the summary of all five systems in this thesis.

Table 3.1: Summary of Bikeshare Systems

\begin{tabular}{|l|l|c|c|c|c|}
\hline City, State & System & Year & Total Trips & $\begin{array}{c}\text { Member } \\
\text { Trips }\end{array}$ & $\begin{array}{c}\text { Non- } \\
\text { Member } \\
\text { Trips }\end{array}$ \\
\hline $\begin{array}{l}\text { Washington, } \\
\text { D.C. }\end{array}$ & $\begin{array}{l}\text { Capital } \\
\text { Bikeshare }\end{array}$ & $\begin{array}{c}2012- \\
2019\end{array}$ & $24,716,073$ & $19,620,321$ & $5,095,752$ \\
\hline Chicago, IL & Divvy & $\begin{array}{c}2015- \\
2019\end{array}$ & $18,028,625$ & $13,845,616$ & $4,183,009$ \\
\hline Boston, MA & Bluebike & $\begin{array}{c}2015- \\
2019\end{array}$ & $7,883,904$ & $6,211,713$ & $1,672,191$ \\
\hline $\begin{array}{l}\text { Minneapolis, } \\
\text { MN }\end{array}$ & Nice Ride & $\begin{array}{c}2012- \\
2019\end{array}$ & $3,150,889$ & $1,677,022$ & $1,473,867$ \\
\hline $\begin{array}{l}\text { Los Angeles, } \\
\text { CA }\end{array}$ & Metro & $\begin{array}{c}2017- \\
2019\end{array}$ & 783,733 & 526,569 & 257,164 \\
\hline
\end{tabular}

The individual trip data of each system later was aggregated into daily trip count data with the start of the day occurring at 4:00 AM of the calendar day and ending at 3:59 AM the 
following day. This daily bikeshare trip data was also categorized into daily member and nonmember trip counts. The purpose of changing the start of day from midnight to 4:00 AM is to capture late night bikeshare trips in the systems. Finally, weather data was obtained from the National Oceanic and Atmospheric Administration (2020) and Weather Underground websites (2020). Since the weather at an airport may be similar to the overall weather of the city, weather data from each city's closest international airport weather station was collected for this study. The daily weather data used in this analysis included daily maximum temperature, average wind speed, maximum dewpoint, snowfall, snow depth and precipitation in inches.

In order to help visualize the variation of bikeshare ridership throughout a calendar year, the calendar heatmap in Figure 3.1 shows the difference between the actual number of nonmember bikeshare trips on a specific day and the mean non-member trips of 14 days around that day in Washington D.C. The mean trips were calculated by using a centered moving average with a 14-day time window. By looking at this calendar, one would see whether the actual nonmember bikeshare trips are above or below the average non-member trips of 14 days around that day. It appears that 14 days is a reasonable span length as it can help standardize the effects of holidays and unusual weather conditions. It can be seen that the non-member ridership was generally higher on weekends than weekdays. The non-member ridership remained similar or decreased on weekdays. The heatmap generally shows that federal holidays on weekend had higher non-member ridership than the same federal holidays on weekday such as New Year's Day, Christmas Day, Independence Day, and Veterans Day. Lastly, the Cherry Blossom Festival on Saturday generally show high levels of non-member ridership. 


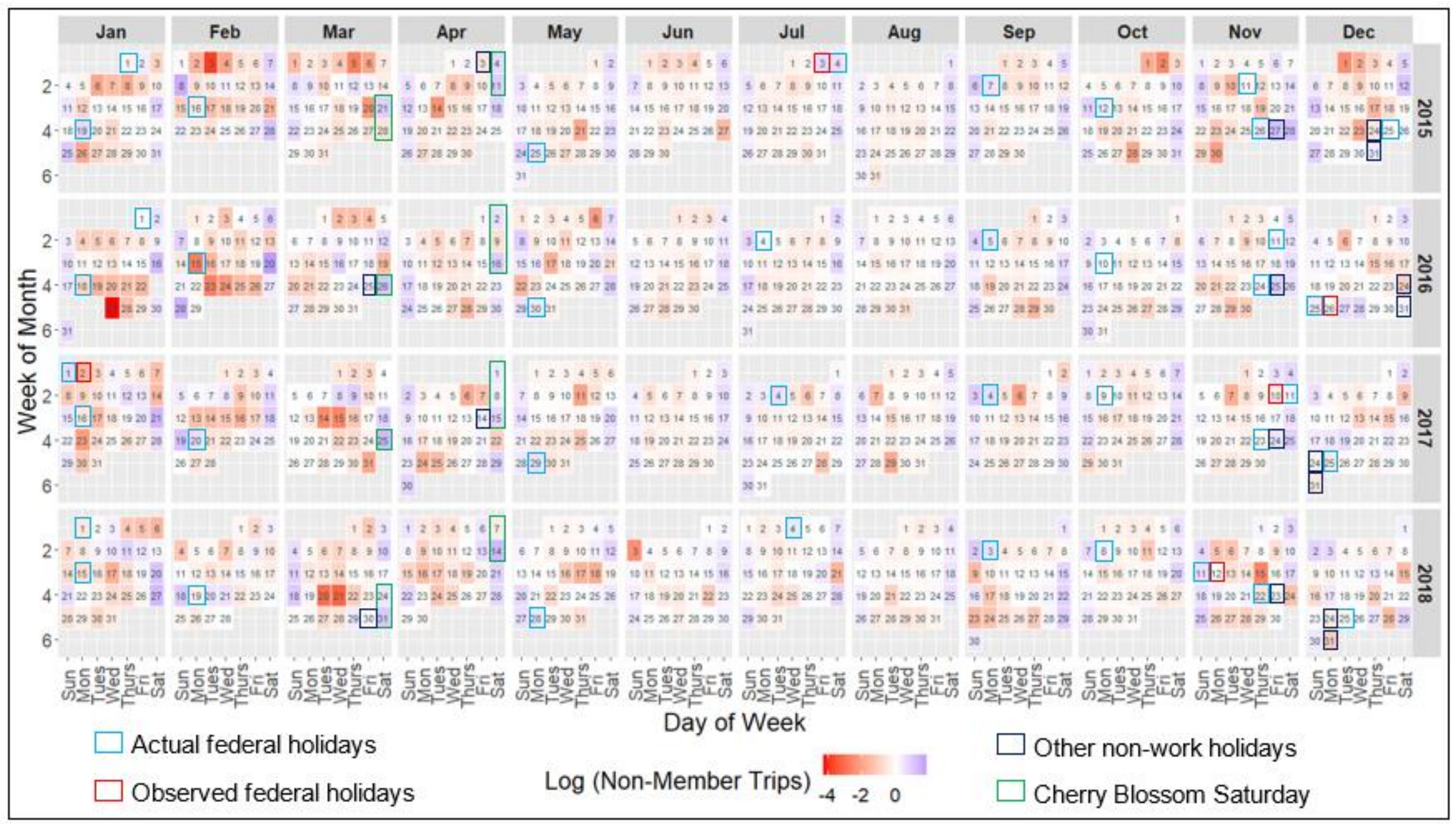

Figure 3.2: Capital Bikeshare Calendar Heatmap for Non-Member Ridership - Log (Ratio of Daily Non-Member Ridership to 14 Day Moving Average Non-Member Ridership) 


\section{Chapter 4: Methodology 4}

This study consists of a multi-city investigation of the effect of holidays on system-level bikeshare ridership in five U.S. cities using a log-linear regression with robust standard errors model. A log-linear regression model resulted in more normally distributed error terms because the system grows over time and has high seasonal variation. Also, this allows the coefficients to be compared across systems because the estimated coefficients show the percent increase or decrease for every one-unit increase in the independent variable. To account for additional heteroscedasticity, the Eicher-Huber-White robust standard errors are reported. The general model specification formula is presented below.

$\log ($ Trips $)=\beta_{0}+\beta_{\mathrm{H}}($ Holidays $)+\beta_{\mathrm{F}}($ CherryBlossom Festival $)+\beta_{\mathrm{T}}($ Temporal $)+$ $\beta_{\mathrm{W}}($ Weather $)$

where $\beta_{0}, \beta_{\mathrm{H}}, \beta_{\mathrm{F}}, \beta_{\mathrm{T}}$, and $\beta_{\mathrm{W}}$ are estimated coefficients regarding the constant, holidays, the Cherry Blossom Festival, temporal fixed effects and weather respectively.

Yearly fixed effects were included to account for changes in the supply of bikes and stations along with the familiarity and demand of the system. Monthly fixed effects were used to account for seasonal variation. The reference variables were the first year of the study period for yearly fixed effects, and July for monthly fixed effects. Variations in ridership over the week were accounted for with daily fixed effects with Wednesday serving as the reference day.

\footnotetext{
${ }^{4}$ Material in this chapter has been submitted to the Transportation Research Board for possible publication.
} 
For testing hypotheses, seven different model specifications were estimated for total, member, and non-member ridership in each system (with the corresponding hypotheses tested in parentheses):

- Federal holidays grouped plus weekend variable (HM1, HM2, HN1, HN2)

- Federal holidays grouped and Saturday and Sunday separately (HT1 - restricted model)

- Federal holiday-specific Effects (HT1 - unrestricted model)

- Non-work holidays grouped by Business Closure Rate (HM3, HN3)

- Holiday-specific Effects (HT2, HN7)

- Holiday-specific Effects with additional grouped by Saturday and Sunday before Monday federal Holidays (HM4, HM5, HN4, HN5)

- Holiday-specific Effects with additional individual Saturday and Sunday before Monday federal Holidays (HT3, HM6, HN6)

The levels of observance for non-work holidays were obtained from the Society for Human Resource Management (2015) which forecasted the percentage of U.S. businesses closed by holiday in 2015. Based on these percentages, non-work holidays were grouped ordinally by observance into three categories from high to low observance for testing hypotheses HN3 and HM3:

- High observance non-work holidays: New Year's Day (95\%), Memorial Day (94\%), Labor Day (95\%), Thanksgiving (97\%) and Christmas (97\%).

- Medium observance non-work holidays: Independence Day (76\%), Day After Thanksgiving (76\%), and Christmas Eve (47\%) 
- Low observance non-work holidays: Birthday of Martin Luther King (37\% of businesses closed), Washington's Birthday (35\%), Good Friday (28\%), Columbus Day (16\%), Veterans Day (20\%), and New Year's Eve (23\%)

For the holiday-specific effects models, all holidays listed above were included individually. Fixed effects were added for each holiday on its corresponding day of the year the holiday falls on to account for the ridership impact of that holiday. For federal holidays which can occur on a weekend day, an additional fixed effect was added for its official day of federal observance. Additionally, when a federal holiday fell on a weekend day, a fixed effect was added to account for differences in ridership compared to when the respective holiday occurs during a weekday.

For Washington D.C., approximately from the third week of March to the second week in April, Capital Bikeshare participates in the National Cherry Blossom Festival by offering the corral service. This service encourages event attendees by guaranteeing a space to dock. In 2018, the average daily trips during the Cherry Blossom Festival was $11.5 \%$ higher than average annual daily trips.

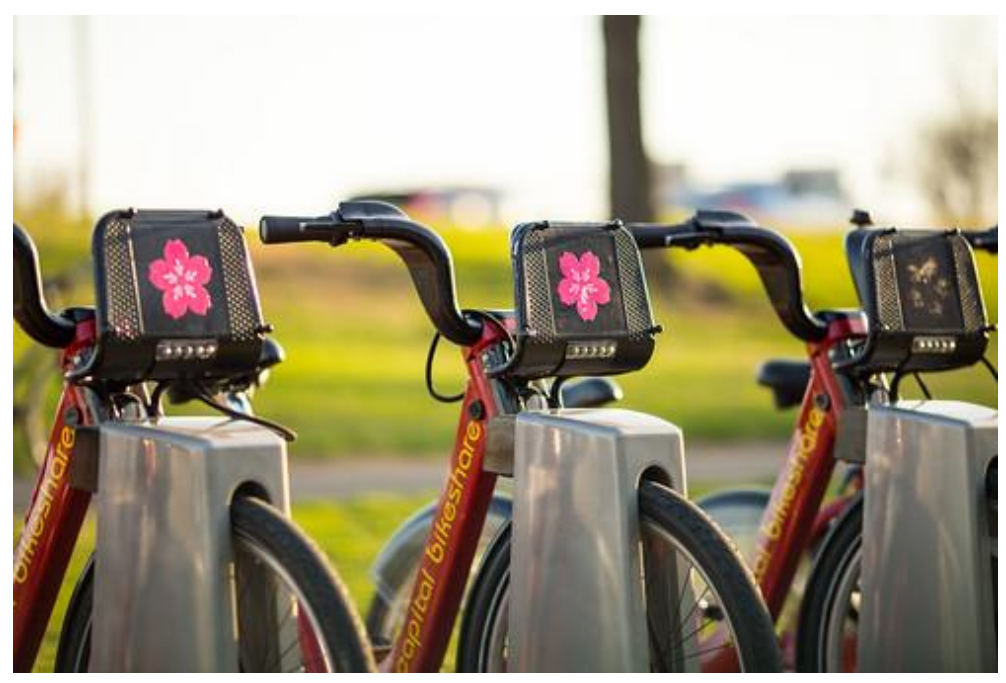

Figure 4.1: Cherry Blossom Festival Corral Service - Capital Bikeshare (Public Domain from https://www.flickr.com/photos/aimeecustis/13789907013/, 2014) 
Weather conditions were controlled for in the model structure with temperature and precipitation modeled non-linearly. For example, bikeshare ridership is expected to increase with temperature (Eren and Uz, 2020), however ridership may drop above a threshold due to excess heat. 


\section{Chapter 5: Theorizing Bikeshare Ridership on Special Calendar Days ${ }^{5}$}

This study proposes to answer the research question: What are the causes of disparities amongst different bikeshare system-level ridership results on holidays in existing literature?

\subsection{Introduction to Hypotheses}

The framework to address these gaps and develop relevant hypotheses are illustrated in Figure 5.1. This framework diagram demonstrates the driving differences in behavior by user type - members and non-members.

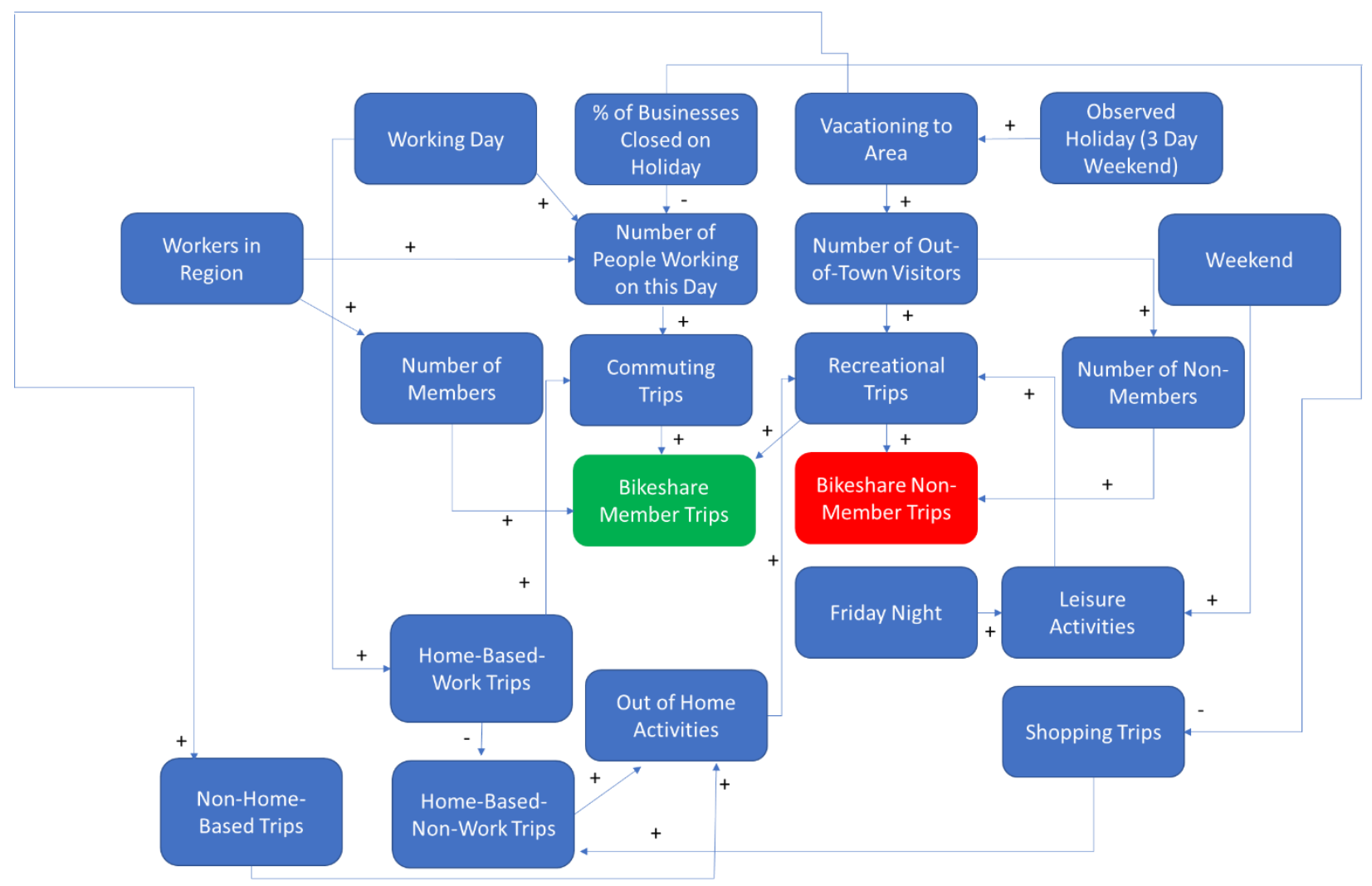

Figure 5.1: Conceptual Framework Diagram on Forming Hypotheses

\footnotetext{
${ }^{5}$ Material in this chapter has been submitted to the Transportation Research Board for possible publication.
} 
It is assumed that members use the bikeshare system for frequent commuting-based trips, whereas non-members use the bikeshare system for less frequent, leisure or tourism related trips. In this analysis, a holiday is defined as a day of recreation or festivity when no work is done. Therefore, it is assumed that the more businesses that are closed on holidays, the less amount of commuting bikeshare users, which would decrease the amount of member trips and increase the amount of non-member trips. Furthermore, if the holiday falls on a Saturday or Sunday, the observed holiday may generate a three-day weekend usually with an observation on Monday. The three-day weekend increases the amount of leisure time available, which may increase vacationing, along with the number of out-of-town visitors, which may increase recreational trips, and would therefore increase bikeshare non-member trips. Although both members and non-members may use the bikeshare system for leisure, the overall assumption in this framework diagram is that there are differences in bikeshare behavior across user types.

The following hypotheses will suggest possible explanations as to why these disparities occur between holidays across different systems and why there is no clear effects on bikeshare usage. The hypotheses are classified into three ridership types for holidays: Member (HM), Nonmember $(\mathrm{HN})$ and Total $(\mathrm{HT})$.

\subsection{Grouped Non-Work Holidays Effects}

Since members can be more likely to use bikeshare for commuting, it is expected that member users would use bikeshare less during their non-workdays, such as federal holidays, and weekends.

- HM1. Federal holidays exhibit lower member ridership compared to non-holidays.

- HM2. Federal holidays have similar member ridership with weekend days. 
In contrast with member users, non-member users are assumed to generally use bikeshare for mostly leisure-based trips. Since non-workdays increase the time available for leisure, nonmember trips are assumed to increase during non-work holidays.

- HN1. Federal holidays exhibit greater non-member ridership compared to nonholidays.

- HN2. Federal holidays have greater non-member ridership than a weekend day. Similarly, variations in holiday observance likely will impact ridership levels on nonwork holidays. It is expected that as holiday observance increases member-level ridership would decrease because of fewer commuting trips. Simultaneously, non-member ridership would increase because of increased leisure.

- HM3. Non-work holidays with higher levels of observance have fewer member trips than holidays with lower levels of observance.

- HN3. Non-work holidays with higher levels of observance have more non-member trips than holidays with lower levels of observance.

It is assumed that the Saturday and Sunday before Monday federal holidays will induce higher member ridership compared to a regular Saturday and Sunday respectively. It is already assumed that members use bikeshare more so for commuting and less so during their nonworkdays, such as weekends. Therefore, it is assumed that if members were to use the bikeshare system for leisure it would be higher on a holiday weekend compared to a regular weekend.

- HM4. The Saturday before a federal holiday induces higher member ridership compared to a regular Saturday.

- HM5. The Sunday before a federal holiday induces higher member ridership compared to a regular Sunday. 
Since non-member users are assumed to predominately use bikeshare for mostly leisurebased trips, it is assumed that the Saturday and Sunday before a Monday federal holiday would induce higher non-member ridership compared to a regular Saturday and Sunday. This assumption is due to a three-day weekend, which would increase the amount of time for leisure.

- HN4. The Saturday before a federal holiday induces higher non-member ridership compared to a regular Saturday.

- HN5. The Sunday before a federal holiday induces higher non-member ridership compared to a regular Sunday.

\subsection{Holidays-Specific Effects}

It is expected that different federal holidays could have dissimilar effects across systems. Hence, this hypothesis is built for testing whether each individual federal holiday has a different effect on total ridership.

- HT1. Ridership levels vary across specific federal holidays.

When federal holidays fall on a weekend day, most often the holiday is observed on the Friday before or the Monday after. Therefore, users may have a three-day weekend and therefore may be more likely to engage in outdoor or leisure activities and utilize bikeshare.

- HT2. Federal holiday on the weekend induces higher ridership compared to the same federal holiday on a weekday.

It is expected that the Saturday and Sunday before Monday federal holidays could have dissimilar effects across holidays. Hence, these hypotheses are built for testing whether each individual Saturday and Sunday before Monday federal holiday has a different effect on total, member and non-member ridership (ex: Saturday Before Memorial Day, Sunday Before Presidents Day, etc.). 
- HT3. Total ridership levels vary across specific Saturday and Sunday before Monday federal holidays.

- HM6. Member ridership levels vary across specific Saturday and Sunday before Monday federal holidays.

- HN6. Non-member ridership levels vary across specific Saturday and Sunday before Monday federal holidays.

\subsection{Cherry Blossom Festival Effects}

The Cherry Blossom Festival in Washington, D.C. is held in the Tidal Basin and along the Potomac River, in an area away from public transit, across a large outdoor space and attracts international and regional tourism. This could cause non-member ridership to rise due to the transient nature of the riders. It assumes that non-members are typically tourists or infrequent users.

- HN7. The Cherry Blossom Festival in Washington D.C. attracts significant tourism which induces higher ridership for non-members. 


\section{Chapter 6: Analysis - Hypothesis Tests ${ }^{6}$}

\subsection{Introduction}

All hypotheses in this study are tested at a 95\% confidence interval across all five systems. The results of the hypothesis testing are summarized in Table 6.1. One-sided $t$-tests, two-sided $t$-tests, one-sided $t$-tests of the equality of two coefficients, and likelihood ratio tests were used to test its respective hypotheses. The $*$ indicates a $p$-value $\geq 0.05$ and a - denotes that a test was not performed for the corresponding test and system.

\subsection{Grouped Non-Work Holidays Effects}

- Hypothesis HM1. The results of the one-sided $t$-tests supports this hypothesis that federal holidays induce lower member ridership versus a non-holiday across all five systems.

- Hypothesis HM2. The results of two-sided $t$-test mostly supports the hypothesis that federal holidays and weekends have similar member ridership in four out of five systems. Capital Bikeshare experienced significantly lower member-level ridership on federal holidays compared to weekends.

- Hypothesis HN1. The one-sided $t$-test results supports this hypothesis that federal holidays have higher ridership for non-members in all cities except Boston. Therefore, it could be roughly concluded the effects of federal holidays and nonholiday days are equivalent in Boston.

\footnotetext{
${ }^{6}$ Material in this chapter has been submitted to the Transportation Research Board for possible publication.
} 
- Hypothesis HN2. The results of the one-sided $t$-test does not support this hypothesis. It was found that federal holidays induce lower non-member ridership than a weekend day, which is opposite to this hypothesis.

- Hypothesis HM3. The results of the one-sided $t$-test supports the hypothesis that the number of member trips decreases proportionally to the levels of observance for nonwork holidays in all systems except in Boston. This means there are no statistically significant differences between the effects of different levels of observance nonworks holidays on member ridership in Boston. This phenomenon can be understood visually in the figure below. Holidays with higher levels of observance, such as Christmas Day (97\%) for example, show lower estimates for members, but holidays with higher levels of observance, such as Good Friday (28\%), show higher estimates. Therefore, for this hypothesis the holidays were grouped ordinally based on percent observance and model results are displayed in Appendix C, Table C.3.

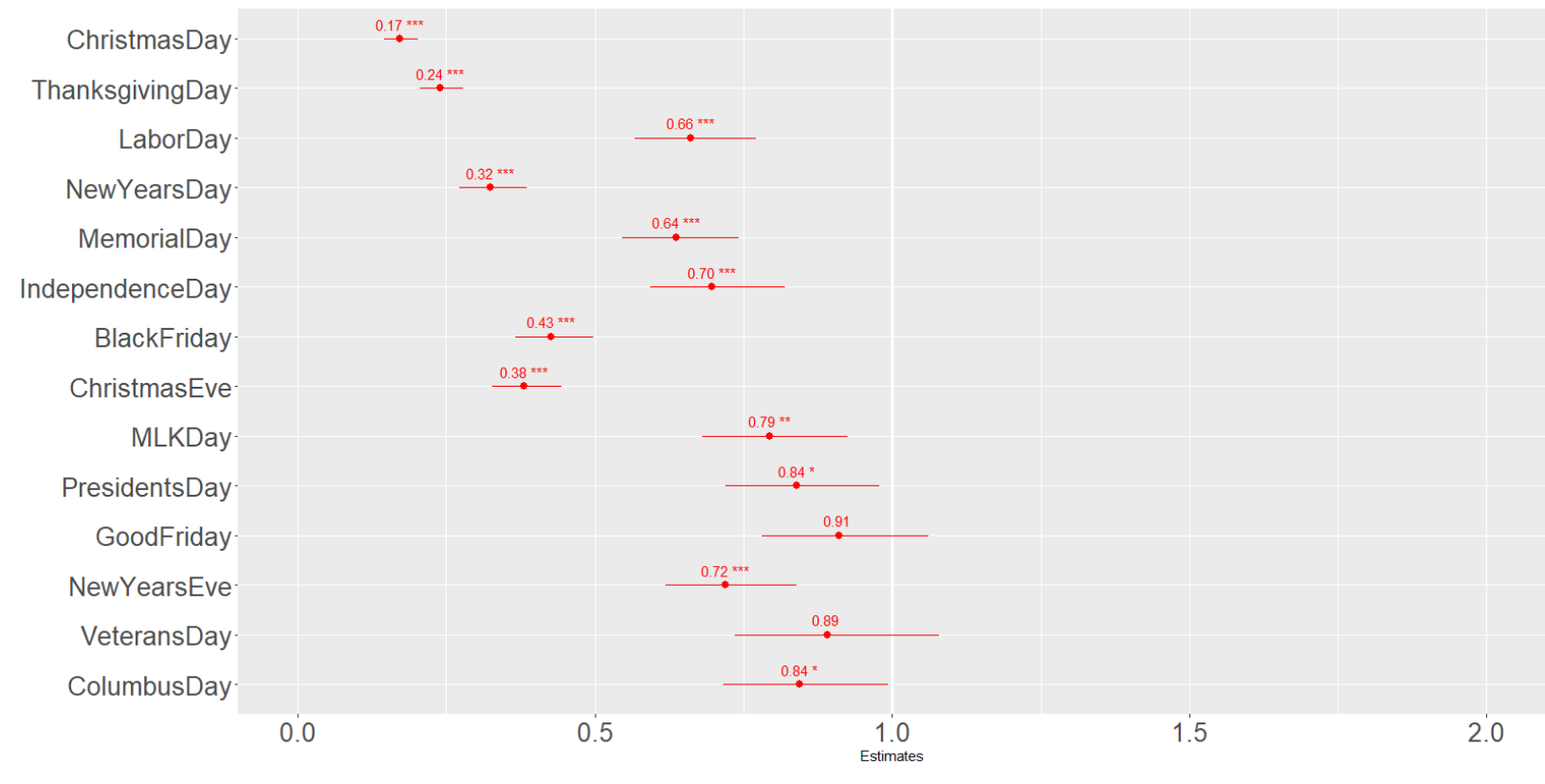

Figure 6.1: Capital Bikeshare Member Model - Expected Ridership Ratio by Holiday 


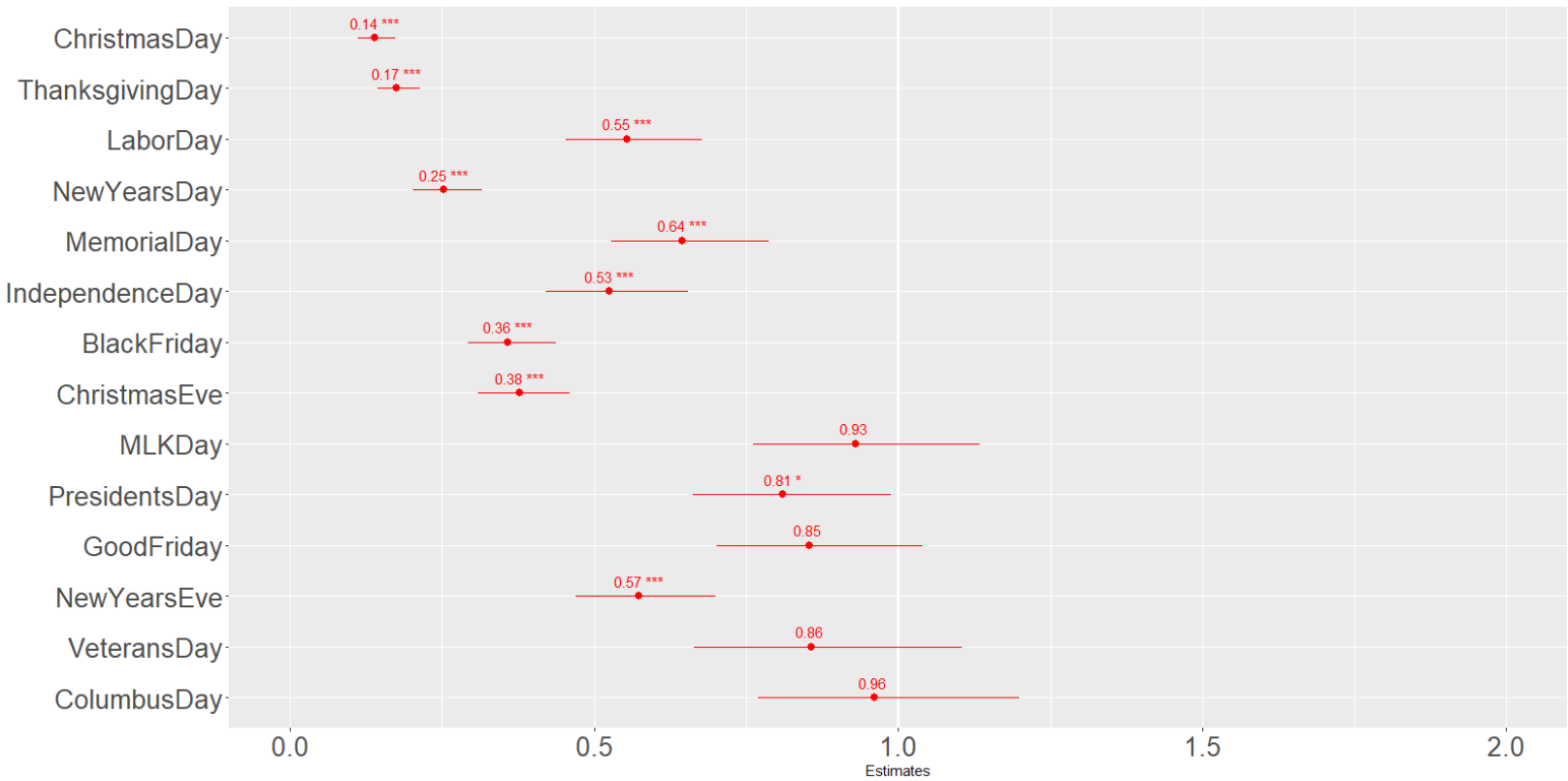

Figure 6.2: Divvy Member Model - Expected Ridership Ratio by Holiday

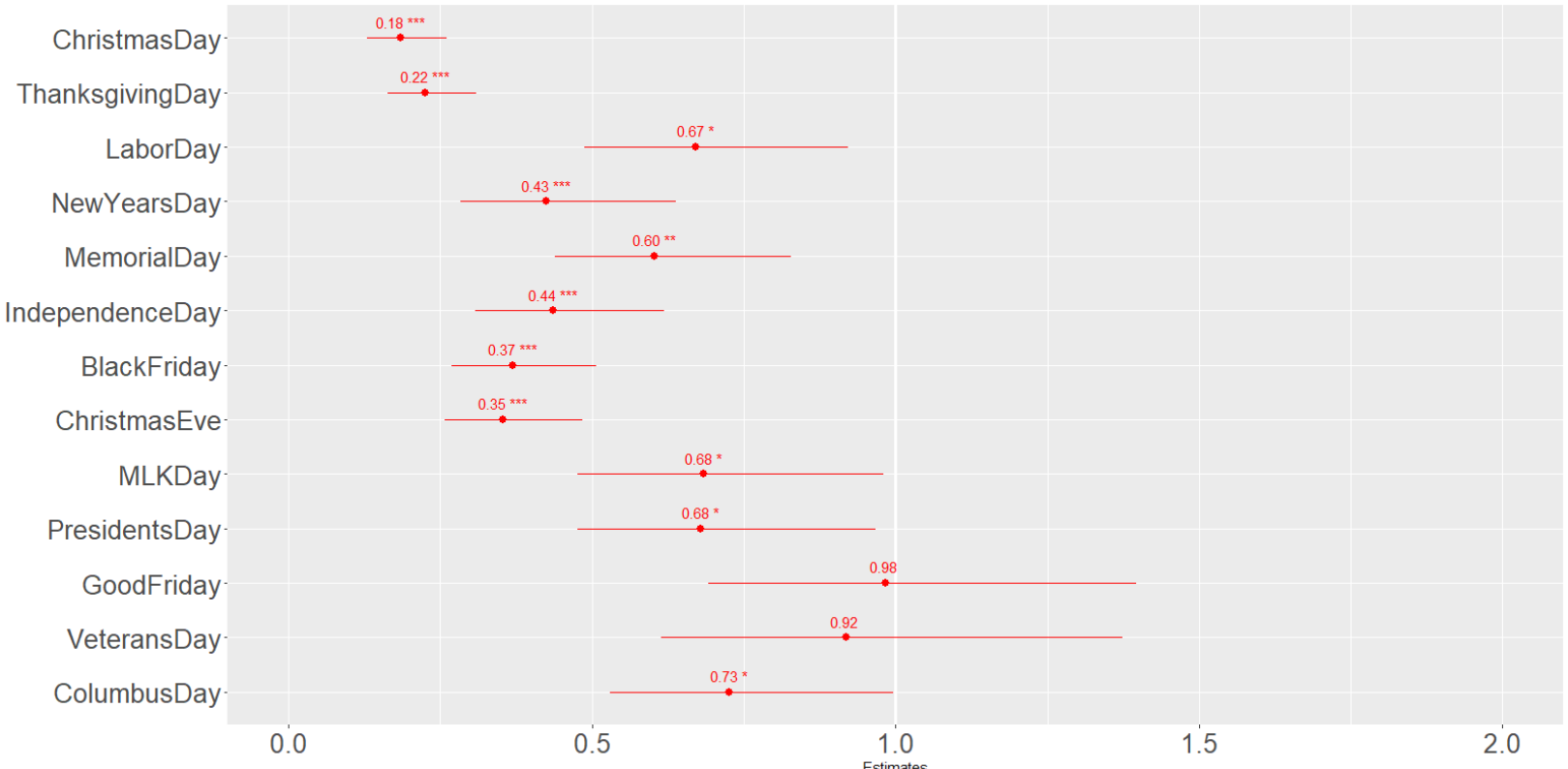

Figure 6.3: Bluebike Member Model - Expected Ridership Ratio by Holiday 


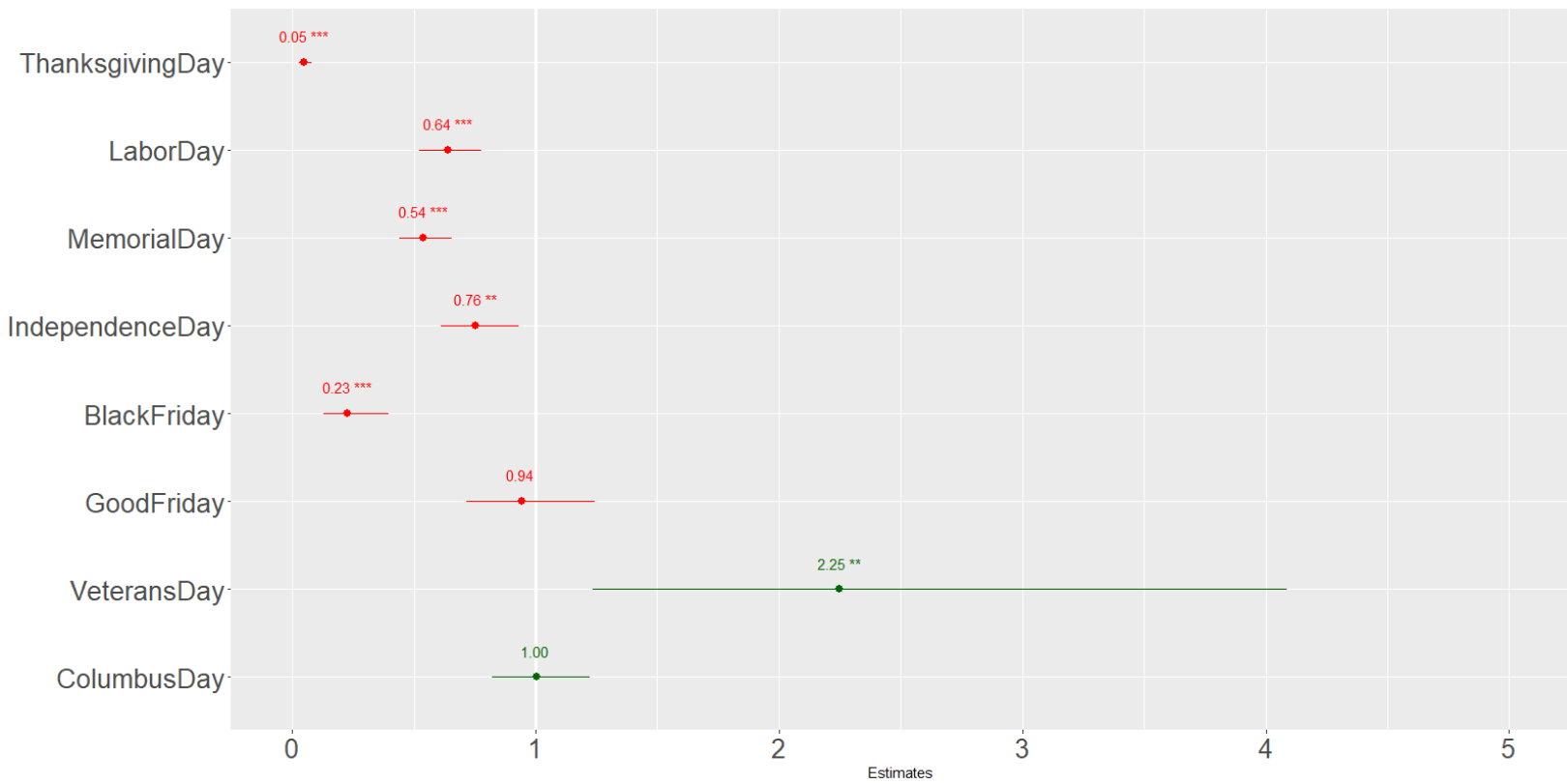

Figure 6.4: Nice Ride Member Model - Expected Ridership Ratio by Holiday

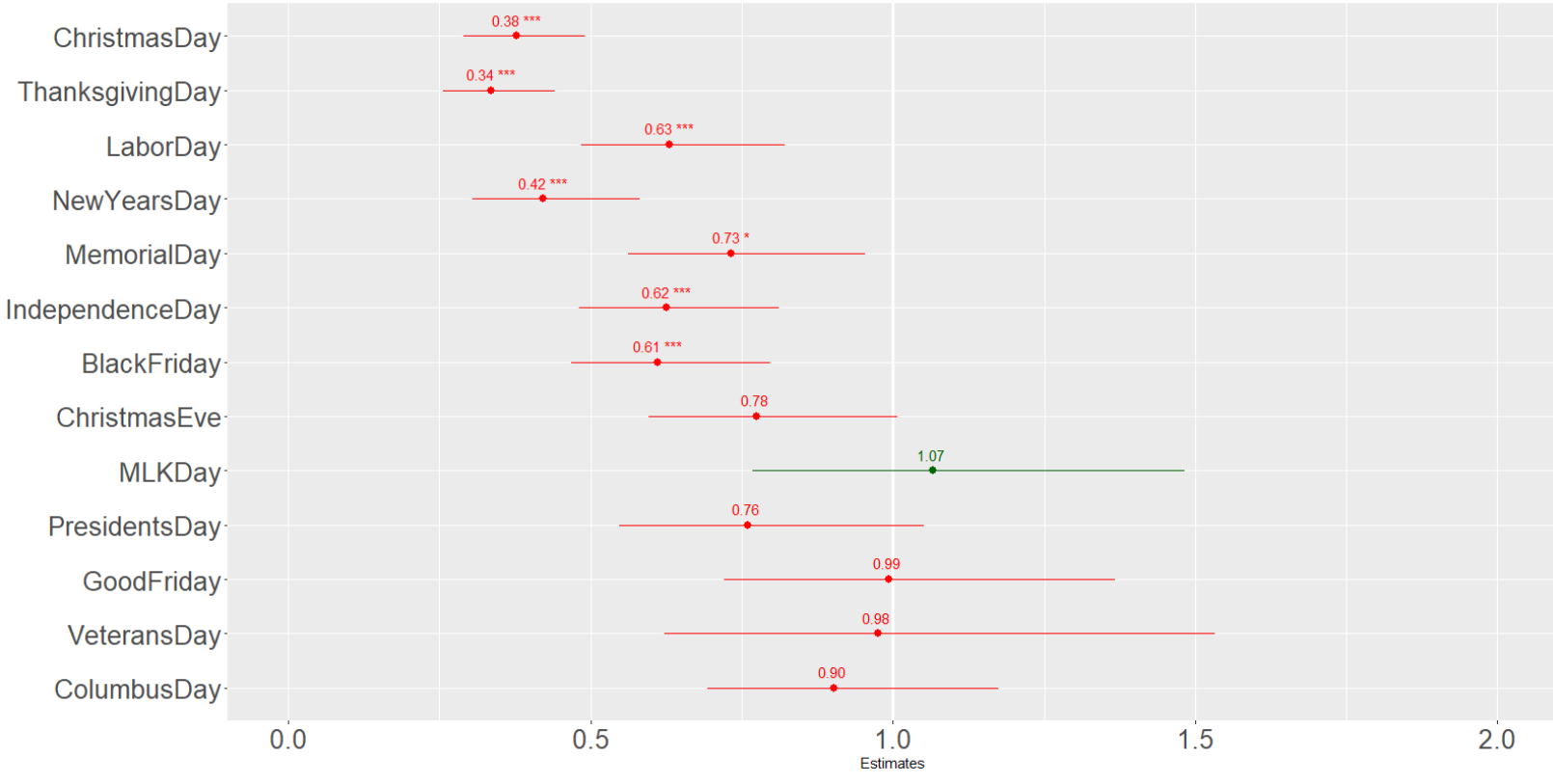

Figure 6.5: Metro Bikeshare Member Model - Expected Ridership Ratio by Holiday

- Hypothesis HN3. After conducting a one-sided $t$-test, the results do not support the hypothesis that the number of non-member trips increases proportionally to levels of observance for non-work holidays in all systems. This means there are no statistically 
significant differences between the effects of different levels of observance nonworks holidays on non-member ridership in all systems.

- Hypothesis HM4. The results of the one-sided $t$-test does not support the hypothesis that the Saturday before a Monday federal holiday induces higher member ridership compared to a regular Saturday.

- Hypothesis HM5. The results of the one-sided $t$-test does not support the hypothesis that the Sunday before a Monday federal holiday induces higher member ridership compared to a regular Sunday.

- Hypothesis HN4. The results of the one-sided $t$-tests supports the hypothesis that the Saturday before a Monday federal holiday induces higher non-member ridership compared to a regular Saturday.

- Hypothesis HN5. The results of the one-sided $t$-tests supports the hypothesis that the Sunday before a Monday federal holiday induces higher non-member ridership compared to a regular Sunday.

\subsection{Holidays-Specific Effects}

- Hypothesis HT1. The results support this hypothesis in all five systems; the effects of individual federal holidays on total bikeshare ridership in each system are different.

- Hypothesis HT2. This hypothesis tests whether federal holidays on a weekend induce higher ridership compared to the same federal holiday on a weekday. To test this hypothesis, a one-sided $t$-test was conducted based on the results of the econometric model displayed in Table 7.1. New Year's Day, Christmas Day, Independence Day, and Veterans Day can occasionally fall on a weekend. After conducting a one-sided $t$ - 
test, the hypotheses are generally supported on New Year's Day, Christmas Day, and Independence Day.

- Hypothesis HT3. This hypothesis shows support that the effects of individual Saturday and Sunday before Monday federal holidays on total bikeshare ridership in each system are different for Capital Bikeshare and Divvy. These are two of the three largest systems in this analysis with a popular bikeshare culture. Therefore, the behavior of the weekend before different Monday federal holidays may exhibit dissimilar changes in ridership.

- HM6. This hypothesis does not show support that ridership levels vary across specific Monday before federal holidays for members except for Divvy. Therefore, the individual Saturday and Sunday before Monday federal holidays do not have to be modeled separately and likely can be grouped.

- HN6. This hypothesis shows support that the effects of individual Saturday and Sunday before Monday federal holidays on non-member bikeshare ridership in each system are different for Capital Bikeshare and Divvy only. Again, these are two of the three largest systems in this analysis with a popular bikeshare culture. Therefore, the behavior of the weekend before different Monday federal holidays may exhibit dissimilar changes in ridership.

\subsection{Cherry Blossom Festival}

- Hypothesis HN7. After conducting a one-sided $t$-test, the results support the hypothesis that the Cherry Blossom Festival in Washington, D.C. induces higher nonmember ridership on Saturdays and on weekdays. 
Table 6.1: Hypothesis Test Results

\begin{tabular}{|c|c|c|c|c|c|c|c|}
\hline $\begin{array}{l}\text { Hypothe- } \\
\text { ses }\end{array}$ & Test & $\begin{array}{l}\text { Alternative } \\
\text { Hypothesis }\end{array}$ & $\begin{array}{c}\text { Capital } \\
\text { Bike- } \\
\text { share }\end{array}$ & Divvy & Bluebike & $\begin{array}{l}\text { Nice } \\
\text { Ride }\end{array}$ & $\begin{array}{c}\text { Metro } \\
\text { Bike- } \\
\text { share }\end{array}$ \\
\hline \multicolumn{8}{|c|}{ Non-work holidays effects } \\
\hline HM1 & One-sided $t$-test & $\begin{array}{l}\text { Grouped federal } \\
\text { holidays }<0\end{array}$ & $-10.27 *$ & $-7.74 *$ & $-8.54 *$ & $-5.49 *$ & $-6.71 *$ \\
\hline HM2 & $\begin{array}{l}\text { Two-sided } t \text {-test of the } \\
\text { equality of two coefficients }\end{array}$ & $\begin{array}{l}\text { Grouped federal } \\
\text { holidays } \neq \text { Weekend }\end{array}$ & $-3.94 *$ & -0.96 & -1.55 & 0.11 & -0.42 \\
\hline HN1 & One-sided $t$-test & $\begin{array}{l}\text { Grouped federal } \\
\text { holidays }>0\end{array}$ & $12.11 *$ & $6.92 *$ & 0.29 & $7.53 *$ & $5.21 *$ \\
\hline HN2 & $\begin{array}{l}\text { One-sided } t \text {-test of the equality } \\
\text { of two coefficients }\end{array}$ & $\begin{array}{l}\text { Grouped federal } \\
\text { holidays > Weekend }\end{array}$ & -3.90 & -4.22 & -2.35 & -2.15 & -0.82 \\
\hline \multirow{2}{*}{ HM3 } & \multirow{2}{*}{$\begin{array}{l}\text { One-sided } t \text {-test of the equality } \\
\text { of two coefficients }\end{array}$} & $\begin{array}{l}\text { High Non-work < } \\
\text { Medium non-work }\end{array}$ & $-3.01 *$ & $-2.38^{*}$ & -0.59 & $-1.82 *$ & $-1.79 *$ \\
\hline & & $\begin{array}{l}\text { Medium non-work < } \\
\text { Low non-work }\end{array}$ & $-7.95^{*}$ & $-6.98 *$ & $-5.15 *$ & $-3.28 *$ & $-2.90 *$ \\
\hline \multirow{2}{*}{ HN3 } & \multirow{2}{*}{$\begin{array}{l}\text { One-sided } t \text {-test of the equality } \\
\text { of two coefficients }\end{array}$} & $\begin{array}{l}\text { High Non-work > } \\
\text { Medium non-work }\end{array}$ & 0.45 & 1.51 & 0.11 & 0.68 & $2.29 *$ \\
\hline & & $\begin{array}{l}\text { Medium non-work > } \\
\text { Low non-work }\end{array}$ & 0.58 & 0.08 & -1.84 & $1.87 *$ & -0.23 \\
\hline HM4 & One-sided $t$-test & $\begin{array}{l}\text { Sat. Before Mon. } \\
\text { Holiday }>0\end{array}$ & -3.68 & -0.63 & -0.61 & -3.53 & $1.91 *$ \\
\hline
\end{tabular}


Table 6.1 (Continued)

\begin{tabular}{|c|c|c|c|c|c|c|c|c|}
\hline HM5 & \multicolumn{2}{|l|}{ One-sided $t$-test } & $\begin{array}{l}\text { Sun. Before Mon. } \\
\text { Holiday }>0\end{array}$ & -2.66 & -0.76 & -0.91 & -2.87 & 1.00 \\
\hline HN4 & \multicolumn{2}{|l|}{ One-sided $t$-test } & $\begin{array}{l}\text { Sat. Before Mon. } \\
\text { Holiday > } 0\end{array}$ & $2.16^{*}$ & $2.57 *$ & 0.16 & $2.05^{*}$ & 0.99 \\
\hline HN5 & \multicolumn{2}{|l|}{ One-sided $t$-test } & $\begin{array}{l}\text { Sun. Before Mon. } \\
\text { Holiday }>0\end{array}$ & $7.20 *$ & $2.40^{*}$ & 0.78 & $4.08^{*}$ & $1.80 *$ \\
\hline \multicolumn{9}{|c|}{ Holiday-specific effects } \\
\hline HT1 & $\begin{array}{l}\text { Likelihood } \\
\text { ratio test }\end{array}$ & $\begin{array}{l}\text { Separate } \\
\text { federal } \\
\text { holidays } \neq \\
\text { Grouped } \\
\text { federal } \\
\text { holidays }\end{array}$ & $\begin{array}{l}350.23 * \\
\mathrm{DF}=13\end{array}$ & $\begin{array}{l}261.30 * \\
D F=13\end{array}$ & $\begin{array}{l}105.97^{*} \\
\mathrm{DF}=13\end{array}$ & \multicolumn{2}{|c|}{$\begin{array}{l}47.51 * \\
\mathrm{DF}=7\end{array}$} & $\begin{array}{c}39.55 * \\
D F=10\end{array}$ \\
\hline \multirow[t]{2}{*}{ HT2 } & \multirow[t]{2}{*}{$\begin{array}{c}\text { One-sided } t \text { - } \\
\text { test }\end{array}$} & $\begin{array}{c}\text { New Year's } \\
\text { Day on } \\
\text { weekend > } \\
\text { New Year's } \\
\text { Day on } \\
\text { weekday }\end{array}$ & $3.94 *$ & $9.35 *$ & $3.44 *$ & \multicolumn{2}{|c|}{ - } & - \\
\hline & & $\begin{array}{c}\text { Christmas } \\
\text { Day on } \\
\text { weekend > } \\
\text { Christmas } \\
\text { Day on } \\
\text { weekday }\end{array}$ & $8.61 *$ & -1.93 & $2.75 *$ & \multicolumn{2}{|c|}{ - } & - \\
\hline
\end{tabular}


Table 6.1 (Continued)

\begin{tabular}{|c|c|c|c|c|c|c|c|}
\hline & & $\begin{array}{c}\text { Independence } \\
\text { Day on } \\
\text { weekend > } \\
\text { Independence } \\
\text { Day on } \\
\text { weekday }\end{array}$ & $6.33 *$ & $11.19 *$ & $5.94 *$ & -0.77 & - \\
\hline & & $\begin{array}{c}\text { Veterans Day } \\
\text { on weekend > } \\
\text { Veterans Day } \\
\text { on weekday }\end{array}$ & 1.10 & -0.63 & -0.25 & -8.53 & 0.51 \\
\hline HT3 & $\begin{array}{l}\text { Likelihood } \\
\text { ratio test }\end{array}$ & $\begin{array}{c}\text { Separate } \\
\text { Sat./Sun. } \\
\text { before Mon. } \\
\text { federal } \\
\text { holidays } \neq \\
\text { Grouped } \\
\text { Sat./Sun. } \\
\text { before Mon. } \\
\text { federal } \\
\text { holidays }\end{array}$ & $\begin{array}{l}20.57 * \\
\mathrm{DF}=8\end{array}$ & $\begin{array}{l}83.31 * \\
\mathrm{DF}=8\end{array}$ & $\begin{array}{c}5.12 \\
\mathrm{DF}=8\end{array}$ & $\begin{array}{c}5.65 \\
\mathrm{DF}=4\end{array}$ & $\begin{array}{r}11.82 \\
\mathrm{DF}=8\end{array}$ \\
\hline HM6 & $\begin{array}{l}\text { Likelihood } \\
\text { ratio test }\end{array}$ & $\begin{array}{c}\text { Separate } \\
\text { Sat./Sun. } \\
\text { before Mon. } \\
\text { federal } \\
\text { holidays } \neq \\
\text { Grouped } \\
\text { Sat./Sun. } \\
\text { before Mon. } \\
\text { federal } \\
\text { holidays }\end{array}$ & $\begin{array}{c}9.04 \\
\mathrm{DF}=8\end{array}$ & $\begin{array}{l}31.49 * \\
\mathrm{DF}=8\end{array}$ & $\begin{array}{c}4.42 \\
\mathrm{DF}=8\end{array}$ & $\begin{array}{c}2.59 \\
\mathrm{DF}=4\end{array}$ & $\begin{array}{c}9.36 \\
\mathrm{DF}=8\end{array}$ \\
\hline
\end{tabular}


Table 6.1 (Continued)

\begin{tabular}{|c|c|c|c|c|c|c|c|}
\hline HN6 & $\begin{array}{c}\text { Likelihood } \\
\text { ratio test }\end{array}$ & $\begin{array}{l}\text { Separate } \\
\text { Sat./Sun. } \\
\text { before Mon. } \\
\text { federal } \\
\text { holidays } \neq \\
\text { Grouped } \\
\text { Sat./Sun. } \\
\text { before Mon. } \\
\text { federal } \\
\text { holidays }\end{array}$ & $\begin{array}{l}17.10^{*} \\
\mathrm{DF}=8\end{array}$ & $\begin{array}{l}29.24 * \\
D F=8\end{array}$ & $\begin{array}{r}10.36 \\
\text { DF }=8\end{array}$ & $\begin{array}{c}3.59 \\
\mathrm{DF}=4\end{array}$ & $\begin{array}{c}8.09 \\
\mathrm{DF}=8\end{array}$ \\
\hline \multicolumn{8}{|c|}{ Cherry Blossom Festival effects } \\
\hline \multirow[t]{2}{*}{ HN7 } & \multirow[t]{2}{*}{$\begin{array}{c}\text { One-sided } t \text { - } \\
\text { test }\end{array}$} & $\begin{array}{l}\text { Cherry } \\
\text { Blossom } \\
\text { Saturday >0 }\end{array}$ & $3.57 *$ & - & - & - & - \\
\hline & & $\begin{array}{l}\text { Cherry } \\
\text { Blossom } \\
\text { weekday >0 }\end{array}$ & $3.41 *$ & - & - & - & - \\
\hline
\end{tabular}




\section{Chapter 7: Results - Individual Holiday Effects Models ${ }^{7}$}

In this section, results from the holiday-specific effects models are presented with system-level ridership level aggregated by total, member, and non-member ridership. Fifteen models are presented in the above analysis covering the five bikeshare system and three ridership aggregation levels.

\subsection{Total Trips}

The baseline models of total bikeshare trips in all five systems were estimated with indicator variables for individual holidays (including observed holidays and holidays on weekends). All other factors such as weather characteristics, time characteristics whose effects on bikeshare demand could be substantial were also included in the model estimations. The purpose of estimating these baseline models is to capture the general effects of individual holidays on bikeshare ridership across five systems. The statistically insignificant variables are retained in the models when relevant to the tested hypotheses.

Regarding effects of federal holidays, it was found that there was a negative relationship between total ridership and federal holidays. The total ridership was found to be significantly lower than other federal holidays on New Year's Day, Christmas Day, and Thanksgiving Day in all systems.

For the weekday effects, it was found that all five systems had lower ridership on Mondays than Wednesdays. For other weekdays, the results show that Thursdays had positive

\footnotetext{
${ }^{7}$ Material in this chapter has been submitted to the Transportation Research Board for possible publication.
} 
effects on bikeshare trips for Metro Bikeshare, and Fridays had positive effects on ridership for Metro Bikeshare, Nice Ride, and Capital Bikeshare. It was found that Thursdays and Fridays had no effects on the other systems. The positive effects of Fridays could be due to evening trips.

In terms of the weekend, the results show that both Saturdays and Sundays had negative effects on total ridership for all systems except Nice Ride. It was found that Saturdays induce higher total ridership in Nice Ride. Due to the equal distribution between member and nonmember riders, the leisure trips which were made by non-member users on Saturday could account for this finding.

Concerning potential seasonal effects, it was found that all systems except Capital Bikeshare exhibited common patterns. The results show that total ridership was lower in winter and spring, higher in summer, and then reduced again in fall. On the other hand, in Capital Bikeshare the results indicate that there is little variation in the total ridership across all four seasons.

Regarding weather effects on bikeshare ridership, the total bikeshare trips decrease as average wind speed increases for all systems except Metro Bikeshare. It was also found that precipitation from rain (no snow) had negative effects on bikeshare trips in all cities. Similarly, the results show that as snowfall and snow depth increases, total ridership decreases in the systems that experience snow. For temperature effects, total ridership increased quadratically for these systems as the maximum temperature increased. But, once the maximum temperature reached approximately 85 degrees F, ridership dropped in a cubic fashion. Finally, the results show that maximum dewpoint has negative effects on bikeshare trips in all systems. 
Table 7.1: Log-Linear Regression Model Results of Total Bikeshare Trips in Five Systems with Robust Standard Errors

\begin{tabular}{|c|c|c|c|c|c|c|c|c|c|c|}
\hline \multirow[t]{2}{*}{ Variable Description } & \multicolumn{2}{|c|}{$\begin{array}{c}\text { Capital } \\
\text { Bikeshare } \\
\text { Washington } \\
\text { D.C. }\end{array}$} & \multicolumn{2}{|c|}{$\begin{array}{c}\text { Divvy } \\
\text { Chicago }\end{array}$} & \multicolumn{2}{|c|}{$\begin{array}{l}\text { Bluebike } \\
\text { Boston }\end{array}$} & \multicolumn{2}{|c|}{$\begin{array}{c}\text { Nice Ride } \\
\text { Minneapolis }\end{array}$} & \multicolumn{2}{|c|}{$\begin{array}{c}\text { Metro } \\
\text { Bikeshare } \\
\text { Los Angeles }\end{array}$} \\
\hline & Mean & t-stat & Mean & t-stat & Mean & t-stat & Mean & t-stat & Mean & t-stat \\
\hline Constant & 6.82 & 22.24 & 5.73 & 18.24 & 6.92 & 32.63 & 4.61 & 5.30 & 1.04 & 0.36 \\
\hline $\begin{array}{l}\text { New Year's Day (actual days, including } \\
\text { weekend) }\end{array}$ & -0.90 & -10.17 & -0.86 & -3.66 & -1.25 & -25.04 & - & - & -0.22 & -1.42 \\
\hline $\begin{array}{l}\text { New Year's Day Observed (only } \\
\text { observed days, Friday or Monday) }\end{array}$ & -0.84 & -6.52 & -0.20 & -3.76 & -0.60 & -15.29 & - & - & - & - \\
\hline New Year's Day*Weekend & 0.35 & 3.94 & 0.81 & 3.44 & 0.55 & 9.35 & - & - & - & - \\
\hline New Year's Eve & -0.24 & -2.67 & -0.57 & -4.34 & -0.54 & -5.36 & - & - & 0.16 & 0.83 \\
\hline Thanksgiving Day & -1.08 & -17.75 & -1.38 & -18.83 & -1.47 & -37.57 & -1.85 & -9.56 & -0.53 & -2.49 \\
\hline Day After Thanksgiving & -0.54 & -10.97 & -0.93 & -18.22 & -0.88 & -6.37 & -0.84 & -6.17 & -0.27 & -3.40 \\
\hline Christmas Day & -1.31 & -22.72 & -1.59 & -8.86 & -1.59 & -12.33 & - & - & -0.22 & -1.81 \\
\hline Christmas Day Observed & -0.82 & -29.67 & -1.20 & -23.11 & -0.74 & -15.64 & - & - & - & - \\
\hline Christmas Day*Weekend & 0.48 & 8.60 & 0.49 & 2.75 & -0.25 & -1.93 & - & - & - & - \\
\hline Christmas Eve & -0.89 & -16.18 & -1.02 & -13.85 & -0.96 & -8.41 & - & - & -0.27 & -8.72 \\
\hline Birthday of Martin Luther King & -0.16 & -1.20 & -0.44 & -1.77 & 0.00 & -0.02 & - & - & -0.02 & -0.31 \\
\hline Memorial Day & -0.10 & -3.23 & -0.38 & -2.73 & 0.04 & 0.51 & -0.08 & -0.48 & 0.07 & 0.90 \\
\hline Washington's Birthday & -0.05 & -0.87 & -0.28 & -1.05 & -0.16 & -2.41 & - & - & -0.19 & -1.38 \\
\hline
\end{tabular}


Table 7.1 (Continued)

\begin{tabular}{|c|c|c|c|c|c|c|c|c|c|c|}
\hline Independence Day & 0.01 & 0.20 & -0.34 & -3.93 & -0.18 & -2.77 & 0.26 & 3.86 & -0.04 & -0.27 \\
\hline Independence Day Observed & 0.05 & 1.97 & -0.22 & -6.31 & 0.30 & 9.40 & 0.02 & 0.60 & - & - \\
\hline Independence Day*Weekend & 0.37 & 6.33 & 0.53 & 5.94 & 0.78 & 11.19 & -0.06 & -0.77 & - & - \\
\hline Labor Day & -0.16 & -4.63 & -0.25 & -4.49 & -0.24 & -3.30 & 0.17 & 2.90 & -0.08 & -0.93 \\
\hline Columbus Day & -0.09 & -1.84 & -0.30 & -4.02 & 0.04 & 1.05 & 0.03 & 0.32 & -0.11 & -3.13 \\
\hline Veterans Day & -0.07 & -1.26 & -0.06 & -1.24 & -0.13 & -0.54 & 0.60 & 1.83 & -0.05 & -1.80 \\
\hline Veterans Day Observed & 0.06 & 2.68 & -0.04 & -0.46 & 0.21 & 6.45 & -0.11 & -0.45 & -0.04 & -0.72 \\
\hline Veterans Day*Weekend & 0.09 & 1.10 & -0.01 & -0.25 & -0.16 & -0.63 & -1.74 & -8.53 & 0.05 & 0.51 \\
\hline Good Friday & -0.01 & -0.27 & 0.03 & 0.49 & -0.11 & -0.88 & -0.03 & -0.32 & -0.04 & -0.79 \\
\hline Cherry Blossom Festival Saturday & 0.20 & 3.81 & - & - & - & - & - & - & - & - \\
\hline Cherry Blossom Festival Weekday & 0.02 & 1.15 & - & - & - & - & - & - & - & - \\
\hline Monday & -0.04 & -2.40 & -0.06 & -2.24 & -0.05 & -2.65 & -0.07 & -2.91 & -0.03 & -1.67 \\
\hline Tuesday & 0.01 & 1.00 & -0.02 & -0.79 & 0.005 & 0.24 & -0.01 & -0.36 & 0.02 & 1.02 \\
\hline Thursday & 0.01 & 0.75 & 0.01 & 0.38 & 0.00 & -0.01 & 0.01 & 0.27 & 0.04 & 2.50 \\
\hline Friday & 0.04 & 2.93 & -0.02 & -0.85 & 0.00 & 0.06 & 0.11 & 4.15 & 0.07 & 4.22 \\
\hline Saturday & -0.09 & -5.68 & -0.37 & -12.52 & -0.31 & -12.11 & 0.18 & 7.37 & -0.08 & -3.98 \\
\hline Sunday & -0.22 & -13.20 & -0.52 & -17.75 & -0.44 & -16.34 & -0.02 & -0.66 & -0.14 & -5.19 \\
\hline Average wind speed & 0.00 & -3.98 & -0.02 & -7.11 & -0.01 & -5.85 & -0.01 & -5.78 & 0.00 & -0.74 \\
\hline Rainfall indicator & -0.06 & -4.50 & -0.08 & -4.19 & -0.12 & -6.28 & -0.09 & -4.83 & -0.02 & -0.51 \\
\hline Precipitation due to rain (inches) & -0.57 & -9.12 & -0.72 & -9.24 & -0.34 & -6.19 & -0.42 & -7.02 & -1.44 & -5.42 \\
\hline
\end{tabular}


Table 7.1 (Continued)

\begin{tabular}{|c|c|c|c|c|c|c|c|c|c|c|}
\hline Quadratic effects of rainfall & 0.10 & 3.05 & 0.17 & 4.01 & 0.01 & 0.66 & 0.07 & 2.81 & 0.72 & 3.92 \\
\hline Snowfall indicator & -0.07 & -0.56 & -0.06 & -0.69 & -0.03 & -0.62 & -0.13 & -1.14 & - & - \\
\hline Snowfall (inches) & -0.28 & -2.39 & -0.21 & -5.33 & -0.09 & -4.98 & -0.18 & -4.32 & - & - \\
\hline Snow Depth (inches) & -0.14 & -3.49 & - & - & -0.05 & -7.70 & -0.18 & -9.67 & - & - \\
\hline Maximum temperature (in Fahrenheit) & 0.01 & 0.38 & 0.07 & 5.89 & 0.05 & 4.16 & -0.01 & -0.21 & 0.17 & 1.55 \\
\hline $\begin{array}{l}\text { Quadratic effects of maximum } \\
\text { temperature } \div 100\end{array}$ & 0.10 & 2.70 & -0.10 & -2.64 & -0.01 & -0.43 & 0.12 & 2.06 & -0.20 & -1.25 \\
\hline $\begin{array}{l}\text { Cubic effects of maximum temperature } \div \\
10,000\end{array}$ & -0.05 & -4.43 & 0.01 & 0.72 & -0.01 & -0.83 & -0.1 & -3.22 & 0.10 & 0.95 \\
\hline $\begin{array}{l}\text { 3-day moving average of maximum } \\
\text { temperature } \div 100\end{array}$ & 0.20 & 1.98 & 1.00 & 3.45 & 0.50 & 3.57 & 1.00 & 3.43 & 0.05 & 0.24 \\
\hline $\begin{array}{l}\text { 30-day moving average of maximum } \\
\text { temperature } \div 10\end{array}$ & 0.10 & 6.69 & 0.03 & 1.10 & 0.10 & 3.79 & 0.10 & 4.54 & 0.04 & 1.37 \\
\hline Maximum dewpoint $\left({ }^{\circ} \mathrm{F}\right) \div 10$ & -0.10 & -8.99 & -0.10 & -4.51 & -0.10 & -8.10 & -0.10 & -9.41 & -0.03 & -1.74 \\
\hline Number of Observation & \multicolumn{2}{|c|}{2,855} & \multicolumn{2}{|c|}{1,704} & \multicolumn{2}{|c|}{1,769} & \multicolumn{2}{|c|}{1,727} & \multicolumn{2}{|c|}{975} \\
\hline R-Squared & \multicolumn{2}{|c|}{0.84} & \multicolumn{2}{|c|}{0.90} & \multicolumn{2}{|c|}{0.90} & \multicolumn{2}{|c|}{0.87} & \multicolumn{2}{|c|}{0.65} \\
\hline Adjusted R-Squared & \multicolumn{2}{|c|}{0.83} & \multicolumn{2}{|c|}{0.89} & \multicolumn{2}{|c|}{0.89} & \multicolumn{2}{|c|}{0.86} & \multicolumn{2}{|c|}{0.64} \\
\hline Durbin Watson's Test & \multicolumn{2}{|c|}{1.62} & \multicolumn{2}{|c|}{0.92} & \multicolumn{2}{|c|}{1.41} & \multicolumn{2}{|c|}{1.38} & \multicolumn{2}{|c|}{1.20} \\
\hline MAPE & \multicolumn{2}{|c|}{0.17} & \multicolumn{2}{|c|}{0.24} & \multicolumn{2}{|c|}{0.21} & \multicolumn{2}{|c|}{0.21} & \multicolumn{2}{|c|}{0.12} \\
\hline
\end{tabular}




\subsection{Member and Non-Member Trips}

New Year's Day and Independence Day on the weekend induce higher total and member ridership but lower non-members ridership. For Labor Day, total and member ridership exhibits negative effects whereas non-members exhibit positive effects. The results show that the ridership was lower on Thanksgiving Day for total and member but remain the same for nonmember ridership. These findings reflect the fact that members are the predominant percentage of the bikeshare population. Therefore, breaking down member and non-member trips is crucial for understanding which type of users are using the bikeshare system on these special days.

A non-federal holiday, such as the day after Thanksgiving generally has lower ridership for both members and non-members. But, for non-members in Washington D.C., there is increased ridership on the Day After Thanksgiving. Generally, Good Friday exhibits no effect on bikeshare ridership.

There is significantly higher ridership during the Cherry Blossom Festival in Washington, D.C. on Saturday for both members and non-members. It could be because this is a large annual event that attracts both residents and tourists. But, on the weekdays during this event, members show no increase in ridership. This may propose that on the weekday, members are using the bikeshare system to go to work, rather than leisure activities. Conversely, non-member ridership is high on the weekday of this festival. This may be that these non-members are tourists.

The results in Table 7.2 and Table 7.3 show that on Fridays, Saturdays and Sundays, member trips were lower compared to Wednesdays, while non-member trips were higher. This could reflect the findings of lower total ridership on Fridays and weekends because members dominate the bikeshare culture. However, in Nice Ride, since the member and non-member trips share an even distribution amongst the system, total ridership was higher on the weekend. 
Table 7.2: Log-Linear Regression Model Results of Member Bikeshare Trips in Five Systems with Robust Standard Errors

\begin{tabular}{|c|c|c|c|c|c|c|c|c|c|c|}
\hline \multirow[t]{2}{*}{ Variable Description } & \multicolumn{2}{|c|}{$\begin{array}{c}\text { Capital } \\
\text { Bikeshare } \\
\text { Washington } \\
\text { D.C. }\end{array}$} & \multicolumn{2}{|c|}{$\begin{array}{c}\text { Divvy } \\
\text { Chicago }\end{array}$} & \multicolumn{2}{|c|}{$\begin{array}{c}\text { Bluebike } \\
\text { Boston }\end{array}$} & \multicolumn{2}{|c|}{$\begin{array}{c}\text { Nice Ride } \\
\text { Minneapolis }\end{array}$} & \multicolumn{2}{|c|}{$\begin{array}{c}\text { Metro } \\
\text { Bikeshare } \\
\text { Los Angeles }\end{array}$} \\
\hline & Mean & t-stat & Mean & t-stat & Mean & t-stat & Mean & t-stat & Mean & t-stat \\
\hline Constant & 6.75 & 24.09 & 5.77 & 18.27 & 6.66 & 36.01 & 4.10 & 4.80 & 1.88 & 0.64 \\
\hline $\begin{array}{l}\text { New Year's Day (actual days, including } \\
\text { weekend) }\end{array}$ & -1.13 & -16.57 & -0.88 & -5.03 & -1.38 & -23.23 & - & - & -0.90 & -4.13 \\
\hline $\begin{array}{l}\text { New Year's Day Observed (only } \\
\text { observed days, Friday or Monday) }\end{array}$ & -0.90 & -8.74 & -0.33 & -5.85 & -0.73 & -22.23 & - & - & - & - \\
\hline New Year's Day*Weekend & 0.47 & 7.14 & 0.73 & 4.26 & 0.72 & 11.11 & - & - & - & - \\
\hline New Year's Eve & -0.33 & -4.90 & -0.67 & -4.18 & -0.56 & -4.59 & - & - & -0.16 & -0.81 \\
\hline Thanksgiving Day & -1.43 & -37.89 & -1.50 & -24.51 & -1.74 & -47.92 & -2.35 & -11.89 & -0.88 & -7.58 \\
\hline Day After Thanksgiving & -0.85 & -28.68 & -0.99 & -15.42 & -1.03 & -10.73 & -1.04 & -7.22 & -0.54 & -3.29 \\
\hline Christmas Day & -1.76 & -25.15 & -1.63 & -6.19 & -1.98 & -31.87 & - & - & -0.91 & -3.48 \\
\hline Christmas Day Observed & -1.17 & -41.57 & -1.25 & -22.45 & -0.98 & -22.61 & - & - & - & - \\
\hline Christmas Day*Weekend & 0.38 & 5.55 & 0.42 & 1.60 & 0.30 & 4.97 & - & - & - & - \\
\hline Christmas Eve & -0.96 & -16.36 & -1.03 & -13.34 & -0.97 & -10.34 & - & - & -0.33 & -3.71 \\
\hline Birthday of Martin Luther King & -0.23 & -1.67 & -0.49 & -2.05 & -0.07 & -0.36 & - & - & -0.11 & -0.67 \\
\hline Memorial Day & -0.45 & -14.20 & -0.51 & -2.69 & -0.44 & -11.79 & -0.60 & -4.05 & -0.32 & -2.18 \\
\hline
\end{tabular}


Table 7.2 (Continued)

\begin{tabular}{|c|c|c|c|c|c|c|c|c|c|c|}
\hline Washington's Birthday & -0.18 & -2.40 & -0.35 & -1.24 & -0.21 & -3.74 & - & - & -0.37 & -6.92 \\
\hline Independence Day & -0.36 & -8.15 & -0.82 & -7.78 & -0.64 & -11.46 & -0.28 & -4.08 & -0.46 & -3.58 \\
\hline Independence Day Observed & -0.38 & -17.64 & 0.00 & -0.12 & -0.33 & -12.89 & -0.42 & -15.59 & - & - \\
\hline Independence Day*Weekend & 0.36 & 6.71 & 1.43 & 12.98 & 0.58 & 9.74 & 0.23 & 3.11 & - & - \\
\hline Labor Day & -0.41 & -10.15 & -0.42 & -5.00 & -0.59 & -5.89 & -0.44 & -4.64 & -0.46 & -2.91 \\
\hline Columbus Day & -0.17 & -4.18 & -0.33 & -4.47 & -0.04 & -0.89 & 0.02 & 0.24 & -0.12 & -3.93 \\
\hline Veterans Day & -0.12 & -1.89 & -0.09 & -1.09 & -0.15 & -0.56 & 0.56 & 1.73 & -0.06 & -1.82 \\
\hline Veterans Day Observed & -0.03 & -0.95 & -0.05 & -0.44 & 0.12 & 4.49 & -0.43 & -1.83 & -0.26 & -2.66 \\
\hline Veterans Day*Weekend & 0.14 & 1.83 & 0.02 & 0.20 & -0.05 & -0.19 & -2.04 & -9.99 & -0.06 & -0.29 \\
\hline Good Friday & -0.09 & -2.32 & -0.01 & -0.10 & -0.16 & -1.62 & -0.08 & -0.98 & -0.05 & -0.41 \\
\hline Cherry Blossom Festival Saturday & 0.09 & 2.16 & - & - & - & - & - & - & - & - \\
\hline Cherry Blossom Festival Weekday & 0.02 & 1.12 & - & - & - & - & - & - & - & - \\
\hline Monday & -0.06 & -4.55 & -0.07 & -2.28 & -0.08 & -4.34 & -0.08 & -3.47 & -0.04 & -1.86 \\
\hline Tuesday & 0.01 & 0.68 & -0.03 & -0.89 & 0.00 & 0.29 & 0.00 & -0.16 & 0.00 & -0.18 \\
\hline Thursday & 0.00 & 0.24 & 0.01 & 0.33 & -0.01 & -0.59 & -0.01 & -0.64 & 0.02 & 0.87 \\
\hline Friday & -0.01 & -0.75 & -0.06 & -1.82 & -0.06 & -3.27 & -0.04 & -1.67 & -0.03 & -1.30 \\
\hline Saturday & -0.34 & -22.47 & -0.53 & -17.19 & -0.60 & -30.91 & -0.40 & -17.13 & -0.44 & -17.00 \\
\hline Sunday & -0.46 & -30.40 & -0.63 & -20.85 & -0.73 & -35.53 & -0.46 & -20.52 & -0.48 & -14.84 \\
\hline
\end{tabular}


Table 7.2 (Continued)

\begin{tabular}{|l|c|c|c|c|c|}
\hline Number of Observation & 2,855 & 1,704 & 1,769 & 1,727 & 975 \\
\hline R-Squared & 0.84 & 0.87 & 0.92 & 0.86 & 0.67 \\
\hline Adjusted R-Squared & 0.83 & 0.86 & 0.91 & 0.85 & 0.65 \\
\hline Durbin Watson's Test & 1.56 & 0.77 & 1.45 & 1.09 & 0.76 \\
\hline MAPE & 0.16 & 0.26 & 0.16 & 0.20 & -0.16 \\
\hline
\end{tabular}

Note: Weather, year, and month variables are excluded from this table but were included in the model estimation results.

- Indicates that the variable is not included in the respective model

Table 7.3: Log-Linear Regression Model Results of Non-Member Bikeshare Trips in Five Systems with Robust Standard

\begin{tabular}{|c|c|c|c|c|c|c|c|c|c|c|}
\hline \multirow{3}{*}{ Variable Description } & \multicolumn{6}{|c|}{ Errors } & & & & \\
\hline & \multicolumn{2}{|c|}{$\begin{array}{c}\text { Capital } \\
\text { Bikeshare } \\
\text { Washington } \\
\text { D.C. }\end{array}$} & \multicolumn{2}{|c|}{ Divvy Chicago } & \multicolumn{2}{|c|}{$\begin{array}{l}\text { Bluebike } \\
\text { Boston }\end{array}$} & \multicolumn{2}{|c|}{$\begin{array}{l}\text { Nice Ride } \\
\text { Minneapolis }\end{array}$} & \multicolumn{2}{|c|}{$\begin{array}{c}\text { Metro } \\
\text { Bikeshare } \\
\text { Los Angeles }\end{array}$} \\
\hline & Mean & t-stat & Mean & t-stat & Mean & t-stat & Mean & t-stat & Mean & t-stat \\
\hline Constant & 1.65 & 3.64 & 0.86 & 1.64 & 3.29 & 12.25 & 2.59 & 3.26 & -2.35 & -0.39 \\
\hline $\begin{array}{l}\text { New Year's Day (actual days, including } \\
\text { weekend) }\end{array}$ & 0.56 & 4.53 & -0.30 & -0.61 & 0.36 & 3.68 & - & - & 0.86 & 11.05 \\
\hline $\begin{array}{l}\text { New Year's Day Observed (only } \\
\text { observed days, Friday or Monday) }\end{array}$ & -0.34 & -1.41 & 1.11 & 13.02 & 0.64 & 9.59 & - & - & - & - \\
\hline New Year's Day*Weekend & -0.56 & -4.67 & 1.27 & 2.56 & -0.15 & -1.35 & - & - & - & - \\
\hline New Year's Eve & 0.53 & 2.52 & 0.02 & 0.06 & 0.13 & 0.48 & - & - & 0.54 & 3.26 \\
\hline Thanksgiving Day & 0.40 & 3.32 & -0.37 & -1.23 & 0.21 & 1.51 & -0.52 & -3.05 & 0.09 & 0.19 \\
\hline
\end{tabular}


Table 7.3 (Continued)

\begin{tabular}{|c|c|c|c|c|c|c|c|c|c|c|}
\hline Day After Thanksgiving & 0.72 & 7.81 & -0.35 & -1.71 & -0.01 & -0.01 & -1.07 & -8.18 & 0.04 & 0.17 \\
\hline Christmas Day & 0.56 & 3.98 & -1.40 & -2.36 & 0.21 & 0.85 & - & - & 0.77 & 4.12 \\
\hline Christmas Day Observed & 0.76 & 15.91 & -0.57 & -6.54 & 0.95 & 12.63 & - & - & - & - \\
\hline Christmas Day*Weekend & -0.20 & -1.42 & 0.79 & 1.34 & -2.34 & -9.23 & - & - & - & - \\
\hline Christmas Eve & -0.21 & -1.20 & -0.74 & -3.92 & -0.35 & -0.88 & - & - & -0.08 & -0.55 \\
\hline Birthday of Martin Luther King & 0.24 & 2.21 & 0.09 & 0.22 & 0.04 & 0.15 & - & - & 0.33 & 3.48 \\
\hline Memorial Day & 0.73 & 14.12 & 0.15 & 0.68 & 1.12 & 9.75 & 0.69 & 4.98 & 0.78 & 11.13 \\
\hline Washington's Birthday & 0.61 & 2.14 & 0.32 & 1.63 & 0.02 & 0.09 & - & - & 0.20 & 0.49 \\
\hline Independence Day & 0.95 & 13.89 & 0.72 & 7.72 & 0.85 & 5.53 & 0.88 & 9.81 & 0.56 & 2.95 \\
\hline Independence Day Observed & 0.92 & 21.33 & -0.96 & -14.50 & 0.88 & 19.14 & 0.24 & 6.58 & - & - \\
\hline Independence Day*Weekend & -0.07 & -0.83 & -2.24 & -20.10 & -0.53 & -3.36 & -0.82 & -8.64 & - & - \\
\hline Labor Day & 0.65 & 6.14 & 0.55 & 1.83 & 0.69 & 4.09 & 1.00 & 13.35 & 0.61 & 3.19 \\
\hline Columbus Day & 0.37 & 3.94 & 0.00 & 0.02 & 0.55 & 7.53 & 0.07 & 0.48 & -0.07 & -0.62 \\
\hline Veterans Day & 0.27 & 2.87 & 0.25 & 0.81 & -0.16 & -0.71 & 0.80 & 2.75 & -0.06 & -1.05 \\
\hline Veterans Day Observed & 0.63 & 10.59 & 0.13 & 1.34 & 0.44 & 7.91 & 0.86 & 4.05 & 0.51 & 10.79 \\
\hline Veterans Day*Weekend & 0.03 & 0.25 & 0.07 & 0.21 & 0.13 & 0.40 & -1.45 & -7.54 & 0.25 & 3.17 \\
\hline Good Friday & 0.26 & 3.05 & 0.35 & 1.48 & 0.37 & 1.41 & 0.19 & 1.44 & 0.04 & 0.32 \\
\hline
\end{tabular}


Table 7.3 (Continued)

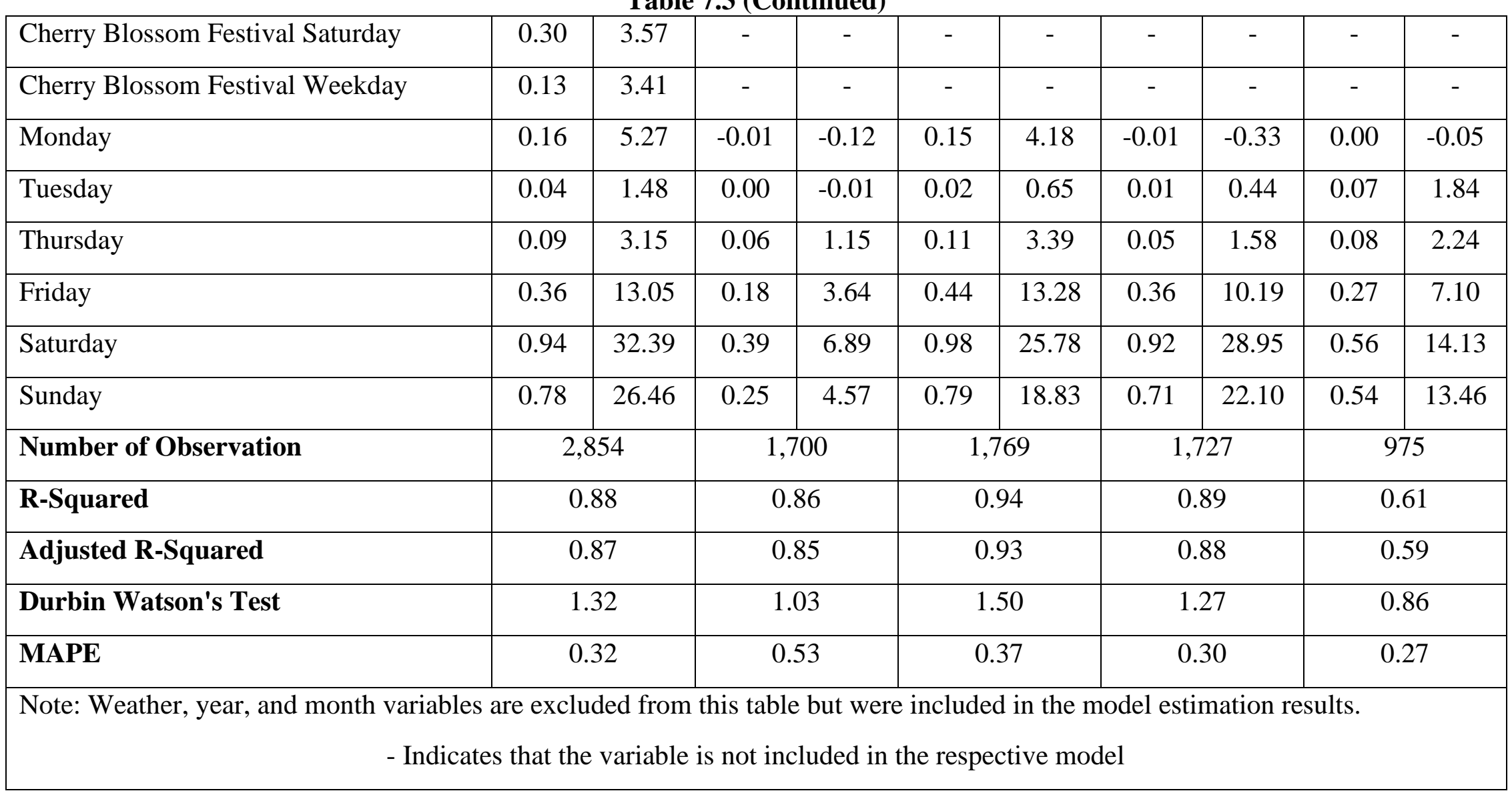




\section{Chapter 8: Special Events Models}

The prior hypotheses only incorporated one special event - the National Cherry Blossom Festival, as it partners with Capital Bikeshare each year. As a result of Capital Bikeshare's partnership, the average daily trips during the National Cherry Blossom Festival in 2018 was $11.5 \%$ higher than average annual daily trips in Washington D.C. There is much difficulty in defining special events due to their variability. This section explores the effects of special events on bikeshare system ridership. First, a classification scheme is utilized to classify the special events used in the analysis. Then, the special events are incorporated into the individual-holiday effects model. Lastly, the model's results are described by special event operation characteristic.

\subsection{Classifying Special Events}

According to the Federal Highway Administration (2002), special events can be classified by their event operation characteristics which include:

- Area Type - Urban, Metro, Rural

- Event Location - Single Venue, Multiple Venues, Fixed Venue, Temporary Venue, Park, Streets

- Event Time of Occurrence - Night/Day, Weekdays/Weekend, Single Day, Multiple Days, Multiple Weeks, Tourist Season

- Event Type - Sports/Concert, Fair/Festival, Parade/Race, Convention

- Event Market Area - Local, Regional, Statewide, National

- Audience Accommodation - Free/Cost, Ticket/Ticketless, General Admission, Reserved Seating 
- Expected Attendance

- Event Time and Duration - Specific Start Time, Predictable Ending Time, Continuous Operation, Multiple Start Times

Table 8.1 illustrates some of these operation characteristics. Due to the lack of tourism data in this thesis, this analysis defines the Event Market based on number of attendees - Local (less than 150,000 attendees), Statewide (greater than or equal to 150,000 attendees, but less than 500,000 ), Regional (greater than or equal to 500,000 attendees, but less than 1.5 million),

National (greater than or equal to 1.5 million attendees).

\subsection{Results - Special Event Models}

In the tables below, the separate holidays models are used, with the addition of special event indicator variables for each bikeshare system. For simplicity of analysis, only the special event variables are shown in the tables below, but it is important to note that the entire separate model was used when producing these outputs. The model specifications for this analysis are in the appendix (Table C.6, Table D.6). The results will be analyzed based on Table 8.1 event operation characteristics: Event Location, Event Time of Occurrence, Event Type, Event Market Area, Audience Accommodation, and Expected Attendance.

Table 8.1: Event Operation Characteristics

\begin{tabular}{|l|l|l|l|l|l|l|l|}
\hline \multicolumn{1}{|c|}{$\begin{array}{l}\text { Event } \\
\text { Name }\end{array}$} & \multicolumn{1}{|c|}{ City } & $\begin{array}{c}\text { Event } \\
\text { Location }\end{array}$ & $\begin{array}{l}\text { Event Time } \\
\text { of } \\
\text { Occurrence }\end{array}$ & $\begin{array}{c}\text { Event } \\
\text { Type }\end{array}$ & $\begin{array}{c}\text { Event } \\
\text { Market } \\
\text { Area }\end{array}$ & \multicolumn{1}{|c|}{ Cost } & $\begin{array}{c}\text { Expected } \\
\text { Attendance }\end{array}$ \\
\hline $\begin{array}{l}\text { Cherry } \\
\text { Blossom } \\
\text { Festival }\end{array}$ & $\begin{array}{l}\text { Washington } \\
\text { D.C. }\end{array}$ & Park & $\begin{array}{l}\text { Multiple } \\
\text { Weeks }\end{array}$ & Festival & National & Free & $1,500,000$ \\
\hline $\begin{array}{l}\text { CicLavia: } \\
\text { Heart of } \\
\text { LA }\end{array}$ & $\begin{array}{l}\text { Los } \\
\text { Angeles }\end{array}$ & Streets & $\begin{array}{l}\text { Weekend, } \\
\text { Single Day } \\
6 \text { times a } \\
\text { year })\end{array}$ & Festival & Local & Free & 100,000 \\
\hline
\end{tabular}


Table 8.1 (Continued)

\begin{tabular}{|c|c|c|c|c|c|c|c|}
\hline \begin{tabular}{|l} 
Aquatennial \\
Fireworks
\end{tabular} & Minneapolis & Park & $\begin{array}{l}\text { Weekend, } \\
\text { Single Day, } \\
\text { Tourist } \\
\text { Season }\end{array}$ & Festival & Statewide & Free & 250,000 \\
\hline \multirow[t]{3}{*}{\begin{tabular}{|l} 
St. Patrick's \\
Day Parade
\end{tabular}} & $\begin{array}{l}\text { Washington } \\
\text { D.C. }\end{array}$ & Streets & Single Day & Parade & Local & Free & 40,000 \\
\hline & Chicago & Streets & Single Day & Parade & Regional & Free & $2,000,000$ \\
\hline & Boston & Streets & Single Day & Parade & Regional & Free & $1,000,000$ \\
\hline Lollapalooza & Chicago & Park & \begin{tabular}{|l} 
Multiple \\
Days, \\
Tourist \\
Season
\end{tabular} & Festival & Statewide & Cost & 400,000 \\
\hline \multirow[t]{2}{*}{ Marathon } & Chicago & Streets & $\begin{array}{l}\text { Weekend, } \\
\text { Single Day }\end{array}$ & Race & Regional & Cost & $1,200,000$ \\
\hline & Boston & Streets & $\begin{array}{l}\text { Weekday, } \\
\text { Single Day }\end{array}$ & Race & Regional & Cost & 500,000 \\
\hline $\begin{array}{l}\text { Air and Water } \\
\text { Show }\end{array}$ & Chicago & Park & $\begin{array}{l}\text { Weekend, } \\
\text { Multiple } \\
\text { Days, } \\
\text { Tourist } \\
\text { Season }\end{array}$ & Festival & National & Free & $2,000,000$ \\
\hline \multirow[t]{4}{*}{ Pride Parade } & $\begin{array}{l}\text { Washington } \\
\text { D.C. }\end{array}$ & Streets & $\begin{array}{l}\text { Weekend, } \\
\text { Single Day, } \\
\text { Tourist } \\
\text { Season }\end{array}$ & Parade & Local & Free & 250,000 \\
\hline & Chicago & Streets & $\begin{array}{l}\text { Weekend, } \\
\text { Single Day, } \\
\text { Tourist } \\
\text { Season }\end{array}$ & Parade & Regional & Free & $1,000,000$ \\
\hline & Boston & Streets & $\begin{array}{l}\text { Weekend, } \\
\text { Single Day, } \\
\text { Tourist } \\
\text { Season }\end{array}$ & Parade & Regional & Free & 750,000 \\
\hline & Minneapolis & Streets & $\begin{array}{l}\text { Weekend, } \\
\text { Single Day, } \\
\text { Tourist } \\
\text { Season }\end{array}$ & Parade & Statewide & Free & 300,000 \\
\hline
\end{tabular}


Table 8.1 (Continued)

\begin{tabular}{|l|l|l|l|l|l|l|l|}
\hline & Los Angeles & Streets & $\begin{array}{l}\text { Weekend, } \\
\text { Single Day, } \\
\text { Tourist } \\
\text { Season }\end{array}$ & Parade & Statewide & Free & 400,000 \\
\hline Jazz Festival & Chicago & Park & $\begin{array}{l}\text { Multiple } \\
\text { Days, }\end{array}$ & Festival & Local & Free & 30,000 \\
\hline $\begin{array}{l}\text { H-Street } \\
\text { Festival }\end{array}$ & $\begin{array}{l}\text { Washington } \\
\text { D.C. }\end{array}$ & Streets & $\begin{array}{l}\text { Weekend, } \\
\text { Single Day }\end{array}$ & Festival & Statewide & Free & 150,000 \\
\hline
\end{tabular}

\subsection{Analysis - Special Event Impacts by Operational Characteristic}

This section analyzes all the individual events chosen in this thesis and compares them against their operational characteristics. If a special event operational characteristic exhibits similar bikeshare ridership effects across all special events in that grouping, it will be easier to predict future bikeshare ridership at events. Finding similar patterns may increase the transferability of the analysis to future bikeshare systems and can determine if corral services and street closures are necessary.

\subsubsection{Event Location}

The special event locations were defined based on if they were on a street or at a park. Overall, park-based events had more positive effects on ridership than street-based events. For example, park-based events such as the Cherry Blossom Festival, Air and Water Show, and the Jazz Festival had positive effects on ridership across all user types. Aquatennial Fireworks and Lollapalooza had positive effects for total and member user types, but no effect for nonmembers. Both Aquatennial Fireworks and Lollapalooza are statewide events. This could explain its no-effect non-member nature as it could lead to less out-of-state tourists attending the event. For street-based events, there were mixed effects across user types. Park-based events may be more consistent due to users possibly associating parks with bicycling. 
Table 8.2: Log-Linear Regression Model Results of Total Bikeshare Trips in Five Systems with Robust Standard Errors Separate Model with Additional Special Event Indicator Variables

\begin{tabular}{|c|c|c|c|c|c|c|c|c|c|c|}
\hline \multirow[t]{2}{*}{ Variable Description } & \multicolumn{2}{|c|}{$\begin{array}{c}\text { Capital } \\
\text { Bikeshare } \\
\text { Washington } \\
\text { D.C. }\end{array}$} & \multicolumn{2}{|c|}{$\begin{array}{c}\text { Divvy } \\
\text { Chicago }\end{array}$} & \multicolumn{2}{|c|}{$\begin{array}{c}\text { Bluebike } \\
\text { Boston }\end{array}$} & \multicolumn{2}{|c|}{$\begin{array}{c}\text { Nice Ride } \\
\text { Minneapolis }\end{array}$} & \multicolumn{2}{|c|}{$\begin{array}{c}\text { Metro } \\
\text { Bikeshare } \\
\text { Los Angeles }\end{array}$} \\
\hline & Mean & $t$-stat & Mean & $t$-stat & Mean & $t$-stat & Mean & $t$-stat & Mean & $t$-stat \\
\hline CicLAvia: Heart of LA & - & - & - & - & - & - & - & - & 1.04 & 20.19 \\
\hline Aquatennial Fireworks & - & - & - & - & - & - & 0.17 & 3.21 & - & - \\
\hline St. Patrick's Day Parade & 0.09 & 0.96 & -0.18 & -2.16 & -0.05 & -0.67 & - & - & - & - \\
\hline Lollapalooza & - & - & - & - & 0.13 & 2.24 & - & - & - & - \\
\hline Marathon & - & - & -0.17 & -0.85 & 0.30 & 6.39 & - & - & - & - \\
\hline Air and Water Show & - & - & - & - & 0.31 & 6.38 & - & - & - & - \\
\hline Pride Parade & 0.05 & 0.70 & 0.01 & 0.26 & 0.24 & 2.75 & 0.14 & 1.89 & 0.001 & 0.005 \\
\hline Jazz Festival Saturday & - & - & - & - & 0.38 & 6.33 & - & - & - & - \\
\hline Jazz Festival Sunday & - & - & - & - & 0.50 & 7.55 & - & - & - & - \\
\hline Cherry Blossom Festival Saturday & 0.20 & 3.71 & - & - & - & - & - & - & - & - \\
\hline Cherry Blossom Festival Weekday & 0.01 & 0.51 & - & - & - & - & - & - & - & - \\
\hline H-Street Festival & 0.14 & 4.56 & - & - & - & - & - & - & - & - \\
\hline Monday & -0.04 & -3.32 & -0.06 & -2.20 & -0.05 & -2.51 & -0.06 & -2.84 & -0.03 & -1.70 \\
\hline
\end{tabular}


Table 8.2 (Continued)

\begin{tabular}{|c|c|c|c|c|c|c|c|c|c|c|}
\hline Tuesday & 0.01 & 0.55 & -0.01 & -0.45 & 0.001 & 0.06 & -0.01 & -0.27 & 0.02 & 1.05 \\
\hline Thursday & 0.01 & 1.05 & 0.02 & 0.62 & 0.00 & -0.004 & 0.01 & 0.40 & 0.04 & 2.49 \\
\hline Friday & 0.03 & 2.55 & -0.02 & -0.75 & -0.002 & -0.10 & 0.11 & 4.15 & 0.07 & 4.20 \\
\hline Saturday & -0.10 & -6.65 & -0.36 & -12.56 & -0.32 & -12.48 & 0.18 & 7.05 & -0.08 & -3.96 \\
\hline Sunday & -0.23 & -14.79 & -0.51 & -17.92 & -0.46 & -17.02 & -0.02 & -0.75 & -0.16 & -6.77 \\
\hline
\end{tabular}

Table 8.3: Log-Linear Regression Model Results of Member Bikeshare Trips in Five Systems with Robust Standard Errors Separate Model with Additional Special Event Indicator Variables

\begin{tabular}{|c|c|c|c|c|c|c|c|c|c|c|}
\hline \multirow[t]{2}{*}{ Variable Description } & \multicolumn{2}{|c|}{$\begin{array}{c}\text { Capital } \\
\text { Bikeshare } \\
\text { Washington } \\
\text { D.C. }\end{array}$} & \multicolumn{2}{|c|}{$\begin{array}{c}\text { Divvy } \\
\text { Chicago }\end{array}$} & \multicolumn{2}{|c|}{$\begin{array}{c}\text { Bluebike } \\
\text { Boston }\end{array}$} & \multicolumn{2}{|c|}{$\begin{array}{c}\text { Nice Ride } \\
\text { Minneapolis }\end{array}$} & \multicolumn{2}{|c|}{$\begin{array}{c}\text { Metro } \\
\text { Bikeshare } \\
\text { Los Angeles }\end{array}$} \\
\hline & Mean & $t$-stat & Mean & $t$-stat & Mean & $t$-stat & Mean & $t$-stat & Mean & $t$-stat \\
\hline CicLAvia: Heart of LA & - & - & - & - & - & - & - & - & 1.09 & 8.48 \\
\hline Aquatennial Fireworks & - & - & - & - & - & - & 0.08 & 2.12 & - & - \\
\hline St. Patrick's Day Parade & 0.08 & 0.86 & -0.21 & -2.74 & 0.01 & 0.24 & - & - & - & - \\
\hline Lollapalooza & - & - & - & - & 0.07 & 1.52 & - & - & - & - \\
\hline Marathon & - & - & -0.23 & -1.26 & 0.15 & 3.07 & - & - & - & - \\
\hline Air and Water Show & - & - & - & - & 0.20 & 4.91 & - & - & - & - \\
\hline Pride Parade & 0.03 & 0.54 & 0.01 & 0.08 & 0.15 & 2.67 & 0.14 & 2.30 & 0.01 & 0.16 \\
\hline
\end{tabular}


Table 8.3 (Continued)

\begin{tabular}{|c|c|c|c|c|c|c|c|c|c|c|}
\hline Jazz Festival Saturday & - & - & - & - & 0.12 & 2.46 & - & - & - & - \\
\hline Jazz Festival Sunday & - & - & - & - & 0.09 & 2.08 & - & - & - & - \\
\hline Cherry Blossom Festival Saturday & 0.09 & 2.04 & - & - & - & - & - & - & - & - \\
\hline Cherry Blossom Festival Weekday & 0.01 & 0.40 & - & - & - & - & - & - & - & - \\
\hline H-Street Festival & 0.12 & 4.52 & - & - & - & - & - & - & - & - \\
\hline Monday & -0.07 & -5.94 & -0.07 & -2.19 & -0.07 & -4.25 & -0.08 & -3.41 & -0.04 & -1.90 \\
\hline Tuesday & 0.002 & 0.15 & -0.02 & -0.59 & 0.002 & 0.12 & -0.001 & -0.07 & -0.002 & -0.13 \\
\hline Thursday & 0.005 & 0.39 & 0.02 & 0.55 & -0.01 & -0.52 & -0.01 & -0.51 & 0.02 & 0.83 \\
\hline Friday & -0.02 & -1.52 & -0.05 & -1.72 & -0.06 & -3.44 & -0.04 & -1.66 & -0.03 & -1.32 \\
\hline Saturday & -0.35 & -24.54 & -0.53 & -17.3 & -0.60 & -30.68 & -0.40 & -16.89 & -0.43 & -16.95 \\
\hline Sunday & -0.47 & -33.98 & -0.63 & -21.00 & -0.74 & -34.95 & -0.46 & -20.63 & -0.50 & -16.78 \\
\hline
\end{tabular}

Table 8.4: Log-Linear Regression Model Results of Non-Member Bikeshare Trips in Five Systems with Robust Standard Errors - Separate Model with Additional Special Event Indicator Variables

\begin{tabular}{|c|c|c|c|c|c|c|c|c|c|c|}
\hline \multirow[t]{2}{*}{ Variable Description } & \multicolumn{2}{|c|}{$\begin{array}{c}\text { Capital } \\
\text { Bikeshare } \\
\text { Washington } \\
\text { D.C. }\end{array}$} & \multicolumn{2}{|c|}{ Divvy Chicago } & \multicolumn{2}{|c|}{$\begin{array}{c}\text { Bluebike } \\
\text { Boston }\end{array}$} & \multicolumn{2}{|c|}{$\begin{array}{c}\text { Nice Ride } \\
\text { Minneapolis }\end{array}$} & \multicolumn{2}{|c|}{$\begin{array}{c}\text { Metro } \\
\text { Bikeshare } \\
\text { Los Angeles }\end{array}$} \\
\hline & Mean & t-stat & Mean & t-stat & Mean & t-stat & Mean & t-stat & Mean & t-stat \\
\hline CicLAvia: Heart of LA & - & - & - & - & - & - & - & - & 1.01 & 12.57 \\
\hline
\end{tabular}


Table 8.4 (Continued)

\begin{tabular}{|c|c|c|c|c|c|c|c|c|c|c|}
\hline Aquatennial Fireworks & - & - & - & - & - & - & 0.04 & 0.67 & - & - \\
\hline St. Patrick's Day Parade & 0.26 & 2.18 & 0.12 & 0.50 & -0.06 & -0.51 & - & - & - & - \\
\hline Lollapalooza & - & - & - & - & 0.06 & 0.93 & - & - & - & - \\
\hline Marathon & - & - & 0.13 & 0.30 & 0.46 & 5.03 & - & - & - & - \\
\hline Air and Water Show & - & - & - & - & 0.12 & 1.72 & - & - & - & - \\
\hline Pride Parade & -0.06 & -0.58 & -0.21 & -1.09 & 0.20 & 1.62 & -0.02 & -0.22 & 0.02 & 0.15 \\
\hline Jazz Festival Saturday & - & - & - & - & 0.46 & 3.41 & - & - & - & - \\
\hline Jazz Festival Sunday & - & - & - & - & 0.69 & 4.11 & - & - & - & - \\
\hline Cherry Blossom Festival Saturday & 0.30 & 3.57 & - & - & - & - & - & - & - & - \\
\hline Cherry Blossom Festival Weekday & 0.13 & 3.28 & - & - & - & - & - & - & - & - \\
\hline H-Street Festival & 0.13 & 1.78 & - & - & - & - & - & - & - & - \\
\hline Monday & 0.15 & 5.30 & -0.01 & -0.22 & 0.16 & 4.59 & -0.01 & -0.31 & -0.002 & -0.06 \\
\hline Tuesday & 0.04 & 1.34 & 0.01 & 0.23 & 0.02 & 0.49 & 0.01 & 0.46 & 0.07 & 1.84 \\
\hline Thursday & 0.09 & 3.23 & 0.06 & 1.26 & 0.12 & 3.58 & 0.05 & 1.69 & 0.08 & 2.24 \\
\hline Friday & 0.35 & 13.16 & 0.18 & 3.67 & 0.44 & 13.36 & 0.36 & 10.13 & 0.27 & 7.09 \\
\hline Saturday & 0.93 & 32.74 & 0.40 & 7.00 & 0.97 & 25.33 & 0.92 & 28.45 & 0.56 & 14.15 \\
\hline Sunday & 0.78 & 26.84 & 0.25 & 4.67 & 0.76 & 17.75 & 0.71 & 22.11 & 0.51 & 13.29 \\
\hline
\end{tabular}




\subsubsection{Event Time of Occurrence}

In this category, single-day events and multi-day/week events are analyzed. The Saint Patrick's Day Parade was the only single-day event that does not typically fall on a weekend day. This was also the only event that had negative impacts on total and member ridership in Chicago and no effect otherwise. Since this event is the only event in this analysis that relates to religion, it may not appeal to all users, which therefore could result in fewer rides. The multi-day and multi-week events generally showed increase ridership across all user types. These multi-day events were all park-based, which again could explain this phenomenon.

\subsubsection{Event Type}

The event types in this analysis include races, festivals and parades. Most of the events in this thesis are festivals, but some races and parades were included. The Chicago and Boston Marathons were the only two races included in this thesis. The Boston Marathon showed positive impacts on ridership across all user types, but the Chicago Marathon showed no effects. The Saint Patrick's Day Parade and Pride Parade show mixed effects based on the city they are located in. The different types of festivals overall display positive effects, except Lollapalooza and the Chicago Air and Water Show display no effect for non-members. Festivals appear to have the largest impacts on bikeshare ridership.

\subsubsection{Event Market Area and Expected Attendance}

The event market area is when an event markets to a specific area, depending on its anticipated audience. These events can be local, statewide, regional, or national. As mentioned earlier, due to the lack of tourism data in this thesis, this analysis defines the Event Market based on number of attendees - Local (less than 150,000 attendees), Statewide (greater than or equal to 150,000 attendees, but less than 500,000), Regional (greater than or equal to 500,000 attendees, 
but less than 1.5 million), National (greater than or equal to 1.5 million attendees). The National Cherry Blossom Festival and the Chicago Air and Water Show are both National Events and both attract high amounts of bikeshare across all user types. The other event market areas have mixed effects - positive, negative, no effect. National events may have large impacts on bikeshare due to not only the number of attendees it brings, but the different array of people it brings. Different cultures have diverse travel mode patterns who may use bicycling in their everyday lives.

\subsubsection{Audience Accommodation}

The cost of an event may impact the likelihood of an individual attending that event. This category is broken down into free and cost. The only events that were not free in this analysis are Lollapalooza and the Chicago and Boston Marathons. Lollapalooza displayed an increase in total daily ridership, but no effect otherwise. The Chicago Marathon displayed no effect across all user types and the Boston Marathon displayed an increase in ridership across all user types. Therefore, cost does not seem to be an underlying factor in relation to event and bikeshare usage. 


\section{Chapter 9: Conclusions and Future Work ${ }^{8}$}

This study primarily focused on exploring the impacts of holidays on daily bikeshare ridership of five U.S. bikeshare systems. Compared to prior literature reviewed in this paper, the findings of this study are more spatially and temporally robust as this study considers holiday effects over multiple years and across multiple locations. Log-linear regression models were estimated to infer the impacts of holidays on total, member, and non-member bikeshare trips across hypotheses.

Similar to prior studies, it was found that total system-level ridership tends to decrease on federal holidays compared to comparable non-holidays. But when accounting for heterogeneity in user types, it is observed that non-member riders take more trips on federal holidays while members take fewer trips. To address the differences in ridership patterns between holidays and weekends, this study found support that both federal holidays and weekends share similar effects on ridership, but the direction of the effects are controlled by user types. It is seen that member ridership is lower on federal holidays and weekends while non-member ridership is higher.

The study generally found that the effects of total and member ridership on holidays were negative while non-member ridership was positive. But, the magnitude of the effects varies based on the individual holidays. Thanksgiving and Christmas, for example, experience lower total ridership than Memorial Day and Labor Day. This study also found that the total systemlevel ridership is likely to increase on federal holiday on a weekend compared to the same

\footnotetext{
${ }^{8}$ Material in this chapter has been submitted to the Transportation Research Board for possible publication."
} 
federal holiday on a weekday. Lastly, it was found that holidays with higher observance by businesses resulted in lower member-level ridership which could be due to less commutingbased trips. A summary of member versus non-member ridership during federal and non-work holidays across five systems in month order (January through December) are illustrated below.
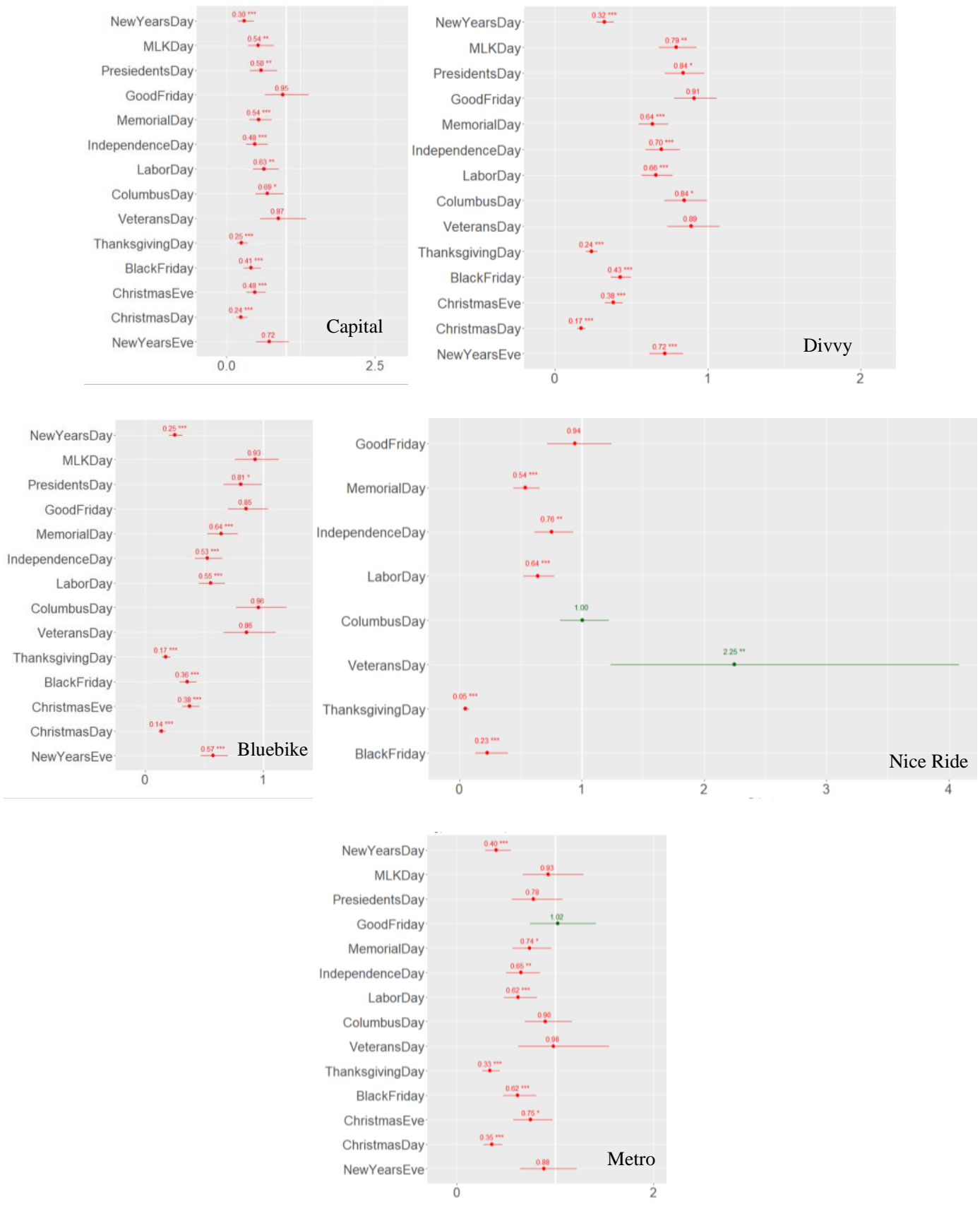

Figure 9.1: Member Models - Expected Ridership Ratio by Different Separate Federal Holidays 


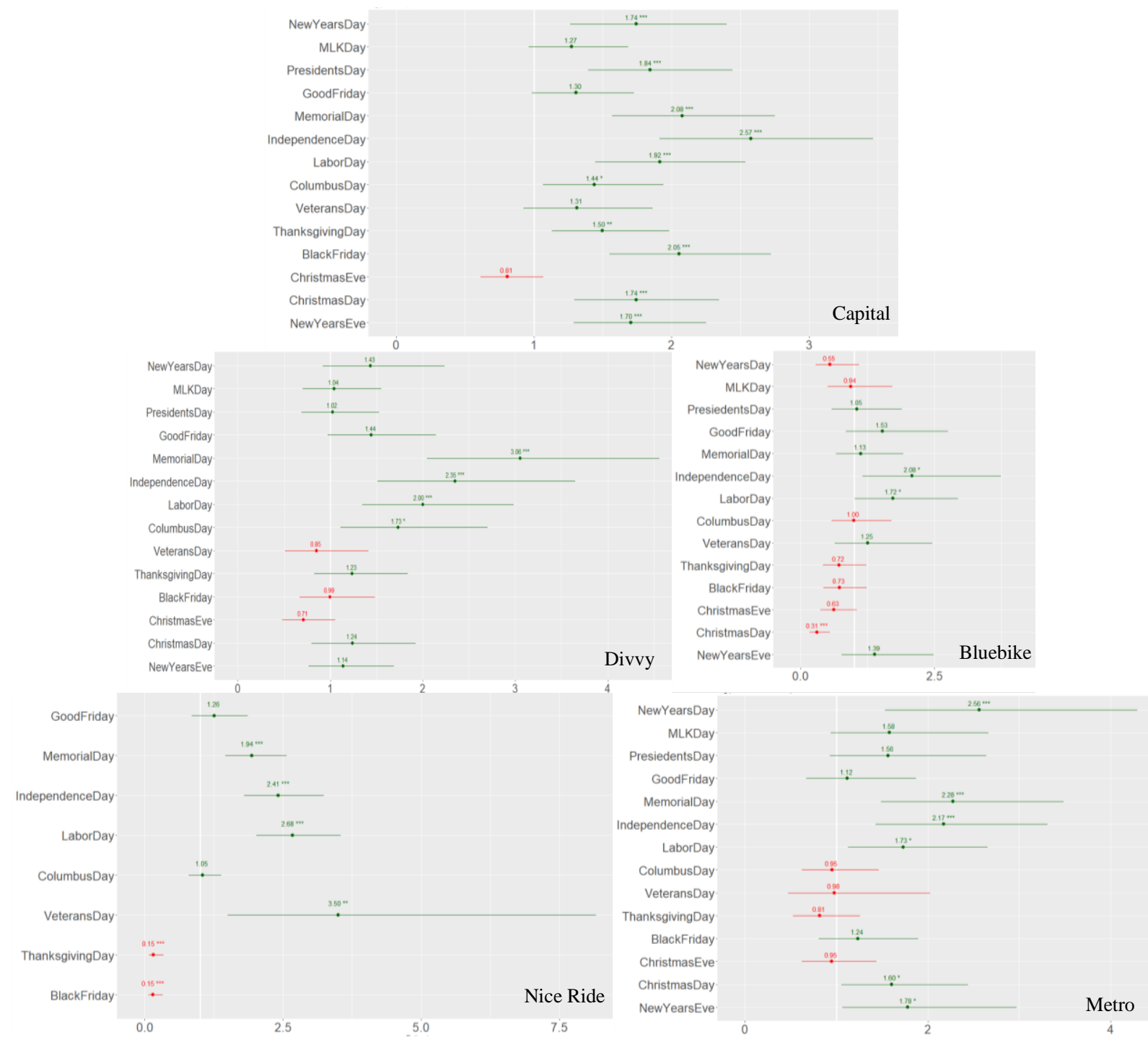

Figure 9.2: Non-Member Models - Expected Ridership Ratio by Different Separate Federal Holidays

In terms of special events, it was found that event operation characteristics impact special event bikeshare ridership. Park-based events had more positive effects on ridership than streetbased events, multi-day events generally showed increases in ridership compared to single day events, and national events contributed to the highest bikeshare numbers. In general, festivals have higher impacts on bikeshare ridership compared to other event types. The National Cherry 
Blossom Festival - being both a national event and a festival - had increased ridership across all bikeshare users' types.

\subsection{Implications}

These findings on bikeshare ridership patterns during special calendar days have implications for the management of bikeshare systems, local economies, and public health. Because of increased non-member ridership on holidays, municipalities and bikeshare systems can concentrate information and advertising campaigns around non-users on holidays. Also, offering a differing ticketing structure, such as reducing the cost of an annual bikeshare pass if one subscribes on a holiday can increase bikeshare efforts on holidays. Local restaurants can aid in this effort by offering discounts during holidays if a user rides the bikeshare to the restaurant. Efforts to increase public awareness and experience with bikeshare systems during holidays may lead to improved public health and additional system membership. The nature of bikeshare systems which induce shorter trips and slower travel speeds can increase local business activity and encourage local patronage in locations with bikeshare. Lastly, the results of this study can aid bikeshare systems in developing general system-level pre-and repositioning efforts and for determining maintenance and cleaning schedules.

In terms of special events, these findings could be useful to urban planners and civic leaders in the consideration of road closures and other traffic changes to ensure pedestrian safety on these special days. Corral services can be offered during high bikeshare volume events to reduce the stress of parking and encourage other active modes. Lastly, planning future events to market to the intended audience can increase bikeshare ridership success. 


\subsection{Future Work}

Future work could examine bikeshare ridership on holidays at the station-level. Analyzing holiday effects at the station-level could aid in understanding where users are traveling which could broaden the understanding of travel behavior patterns on these days. Future work may also explore additional bikeshare systems to strengthen hypothesis results further. Lastly, using a pooled model specification can make comparing across bikeshare systems to understand holiday ridership differences easier.

For special event selection, future work can include analyzing data at the microscopic level. Qualitative study, including interviews, focus group, ethnographies, and surveys, may help to extract the types of special events that are highly correlated to bikeshare usage. For example, Barbour et al. (2019) conducted a web-based survey to collect data on bikeshare usage of registered bikeshare usage. This can be done for non-registered users as well to understand bikeshare ridership during special events. Future work could also seek to build a testable framework using event characteristics and machine learning techniques to explore these impacts.

\subsection{Limitations}

One of the limitations in this study is that although most of the Durbin Watson test statistics show little autocorrelation, some systems show positive autocorrelation, especially for the non-member models. Analyzing systems with the same model specification results in the comparable results across five systems. Although some of the models show autocorrelation, to have consistent and comparable results, the same model specifications were used across all five systems. To account for the autocorrelation issues, the study could be conducted by using an Auto Regressive Integrated Moving Average (ARIMA) model. Another limitation is user trip 
heterogeneity. Members and non-members have trip purposes further than those explored. Using machine learning techniques, such as clustering trips can help infer trip purpose.

The Cherry Blossom Festival induces higher ridership for both members and nonmembers in Washington D.C. But there is very limited research on the effects of special events on bikeshare system ridership. There is no theoretical framework to explain which events are expected to impact bikeshare usage. This thesis attempted to build a framework by defining special events based on FHWA event operation characteristics but was limited due to the lack of tourism data. It was difficult to infer if the event market without knowing the percent of attendees that were residents or other nationals. Gathering tourism data along with event statistics can strengthen this framework. 


\section{References}

Barbour, N., Zhang, Y., and Mannering, F. A statistical analysis of bike sharing usage and its potential as an auto-trip substitute. Journal of Transport and Health, 2019, pp. 253-262.

Bluebikes. System Data. 2020 Motivate International Inc., 2020.

https://www.bluebikes.com/system-data. Accessed January 5, 2020.

Capital Bikeshare. System Data. 2020 Lyft, Inc., 2020.

https://www.capitalbikeshare.com/system-data. Accessed January 5, 2020.

Caulfield, B., O’Mahony, M., Brazil, W., and Weldon, P. Examining usage patterns of a bikesharing scheme in a medium sized city. Transportation Research Part A, 2017, pp. 152-161.

Corcoran, J., Li, T., Rohde, D., Charles-Edwards, E., and Mateo-Babiano, D. Spatio-temporal patterns of a Public Bicycle Sharing Program: the effect of weather and calendar events. Journal of Transport Geography, 2014, pp. 292-305.

Divvy. Divvy Data. 2020 Divvy Bikes, 2020. https://www.divvybikes.com/system-data. Accessed January 5, 2020.

El-Assi, W., Mahmoud, M., and Habib, K. Effects of built environment and weather on bike sharing demand: a station level analysis of commercial bike sharing in Toronto.

Eren, E., and Uz, E. A review on bike-sharing: The factors affecting bike-sharing demand. Sustainable Cities and Society, 2020, Sustainable Cities and Society 54101882.

Faghih-Imani, A., Eluru, N., El-Geneidy, A., Rabbat, M., and Haq, U. How land-use and urban form impact bicycle flows: evidence from the bicycle-sharing system (BIXI) in Montreal. Journal of Transport Geography, 2014, pp. 306-314.

Federal Highway Administration. Chapter Two Characteristics And Categories of Planned Special Events. FHWA, 2002. https://ops.fhwa.dot.gov/publications/fhwaop04010/chapter2.pdf. Accessed September 10, 2020.

Gebhart, K., and Noland, R. The impact of weather conditions on bikeshare trips in Washington, D.C.. Springer Science+Business Media New York, 2014. 10.1007/s11116-014-9540-7.

Hyland, M., Hong, Z., Pinto, H., and Chen, Y. Hybrid cluster-regression approach to model bikeshare station usage. Transportation Research Part A: Policy and Practice, 2018, pp. 71-89. 
Kaltenbrunner, A., Meza, R., Grivolla, J., Codina, J., and Banchs, R. Urban cycles and mobility patterns: Exploring and predicting trends in a bicycle-based public transport system. Pervasive and Mobile Computing, 2010, pp. 455-466.

Kim, K. Investigation on the effects of weather and calendar events on bike-sharing according to the trip patterns of bike rentals of stations. Journal of Transport Geography, 2018, pp. 309-320.

Kutela, B., and Teng, H. The influence of campus characteristics, temporal factors, and weather events on campuses-related daily bike-share trips. Journal of Transport Geography 78, 2019, pp. $160-169$.

Matrai, T., and Toth, J. Comparative assessment of public bike sharing systems. 6th Transport Research Arena, 2016, pp. 2344-2351.

Mattson, J., and Godavarthy, R. Bike-share in Fargo, North Dakota: Keys to success and factors affecting ridership. Sustainable Cities and Society, 2017, pp. 174-182.

Metro Bikeshare. Data. 2018 Metro Bikeshare, 2018. https://bikeshare.metro.net/about/data/. Accessed January 5, 2020.

National Association of City Transportation Officials. Shared Micromobility in the U.S.:2018. NACTO, 2019. https://nacto.org/wp-content/uploads/2019/04/NACTO_Shared-Micromobilityin-2018_Web.pdf. Accessed May 3, 2020.

National Oceanic and Atmospheric Administration. Climate Data Online. Department of Commerce, 2020. https://www.ncdc.noaa.gov/cdo-web/. Accessed February 7, 2020.

Nice Ride. System Data. 2020 Lyft, Inc, 2020. https://www.niceridemn.com/system-data. Accessed January 5, 2020.

Pal, A., and Zhang, Y. Free-floating bike sharing: Solving real-life large-scale static rebalancing problems. Transport Research Part C, 2017, pp. 60-74.

Society for Human Resource Management. SHRM Survey Findings: 2015 Holiday Schedules. SHRM, November 2014. https://www.shrm.org/hr-today/trends-and-forecasting/research-andsurveys/Pages/shrm-2015-holiday-schedules.aspx. Accessed June 15, 2020.

Sun, F., Chen, P., and Jiao, J. Promoting public bike-sharing: A lesson from the unsuccessful Pronto system. Transportation Research Part D: Transport and Environment, 2018, pp. 533547.

Wang, J., and Lindsey, G. Neighborhood socio-demographic characteristics and bike share member patterns of use. Journal of Transport Geography, 2019, 102475.

Weather Underground. History. TWC Product and Technology LLC., 2014, 2020. https://www.wunderground.com/. Accessed February 7, 2020. 
Younes, H., Zou, Z., Wu, J., and Baiocchi, G. Comparing the Temporal Determinants of Dockless Scooter-share and Station-based Bike-share in Washington, D.C. Transportation Research Part A: Policy and Practice, 2020, pp. 208-320.

Zhang, Y., Thomas, T., Brussel, M., and Maarseveen, M. Exploring the impact of built environment factors on the use of public bikes at bike stations: Case study in Zhongshan, China. Journal of Transport Geography, 2017, pp. 59-70.

Zhou, X. Understanding Spatiotemporal Patterns of Biking Behavior by Analyzing Massive Bike Sharing Data in Chicago. PLoS ONE, 2015, 10(1): e0137922. 


\section{Appendix A: Area Plots9}
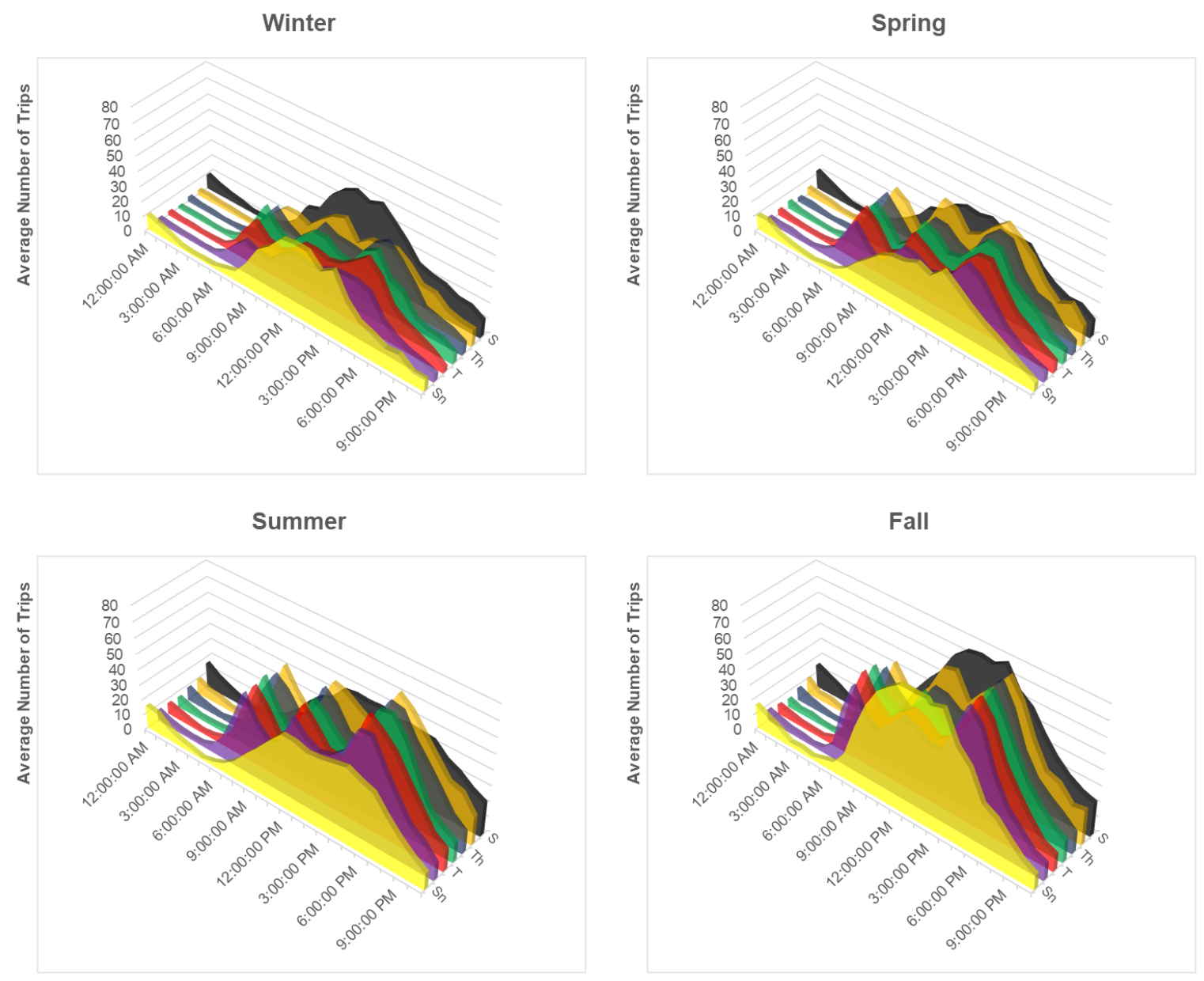

Figure A.1: 2017 Metro Bikeshare (Los Angeles) - Mean Number of Trips vs Time of Day, and Day of Week

9 "Material in this chapter has been submitted to [Journal of Big Data Analytics] for possible publication." 

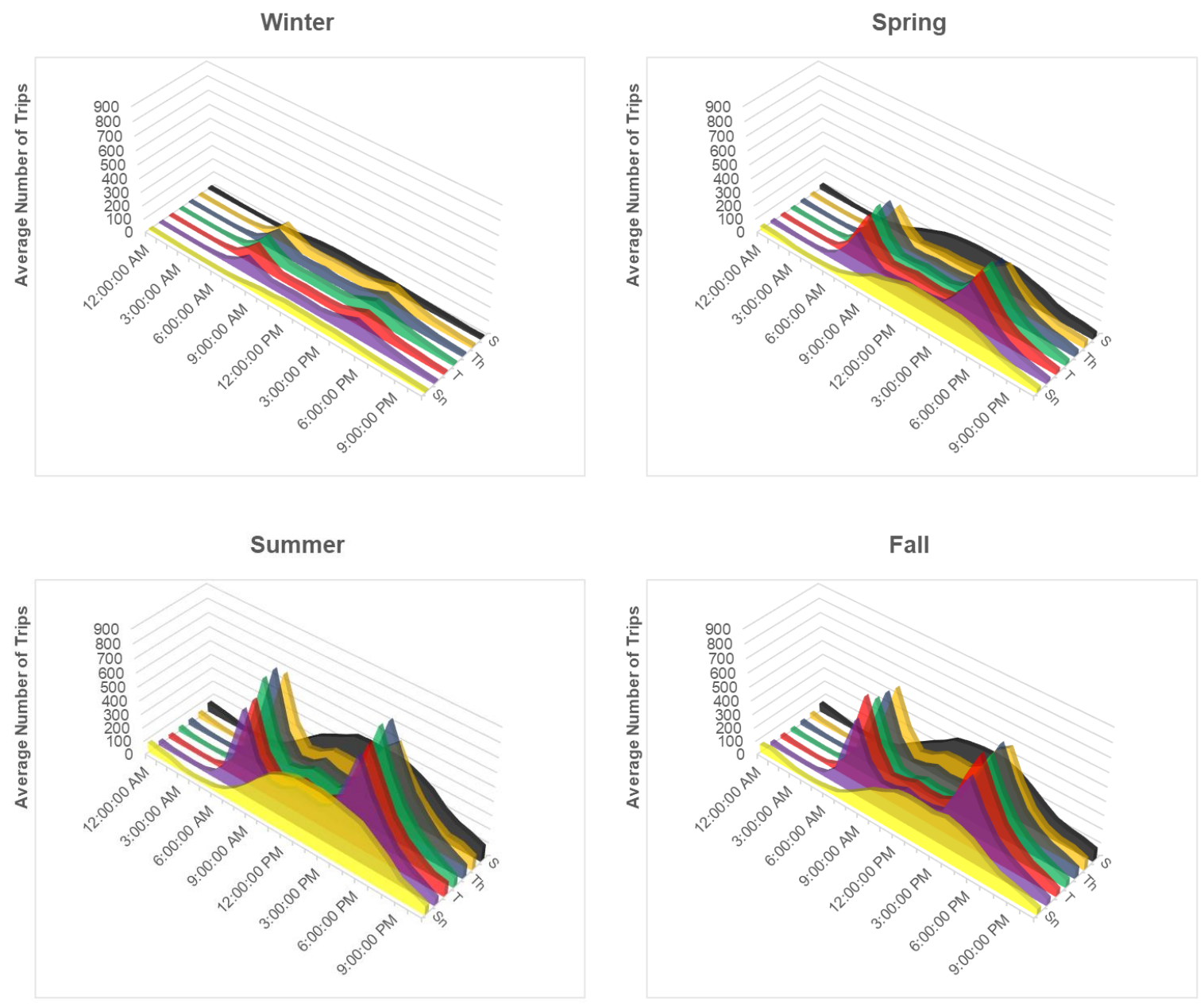

Figure A.2: 2017 Bluebikes (Boston) - Mean Number of Trips vs Time of Day, and Day of Week 

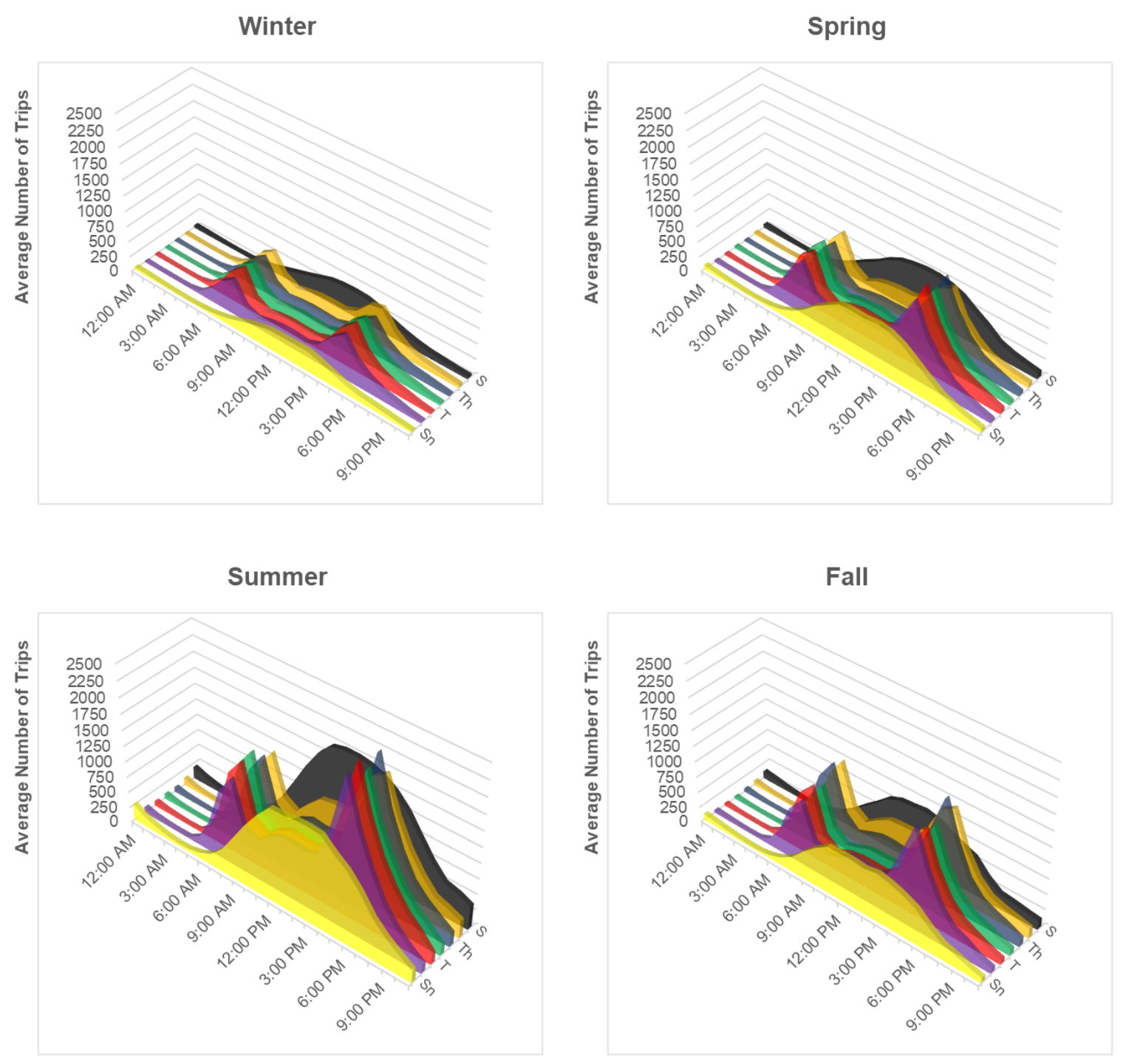

Figure A.3: 2017 Capital Bikeshare (Washington D.C.) - Mean Number of Trips vs Time of Day, and Day of Week 

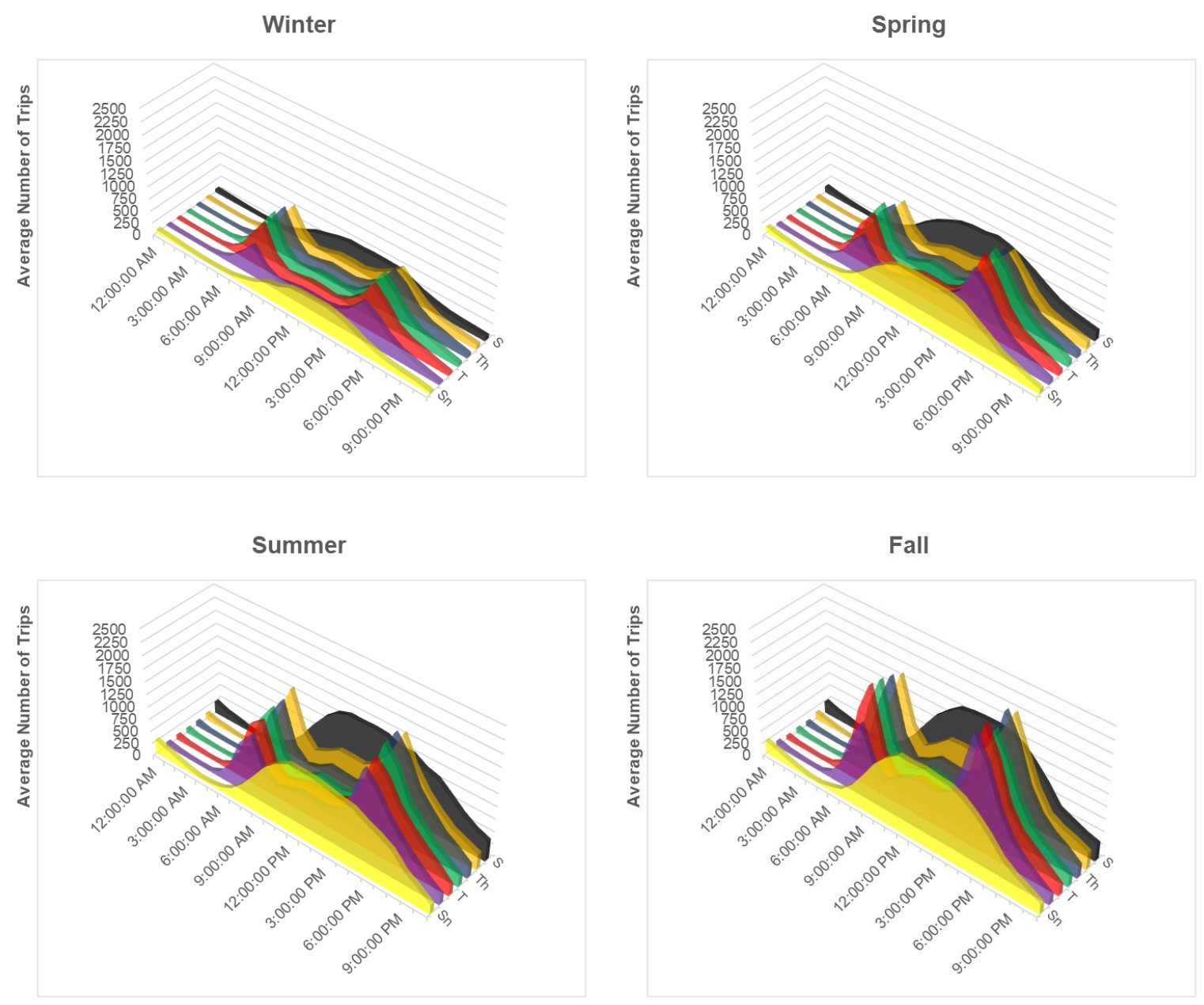

Figure A.4: 2017 Capital Bikeshare (Washington D.C.) - Mean Number of Trips vs Time of Day, and Day of Week 
Appendix B: Heat Maps

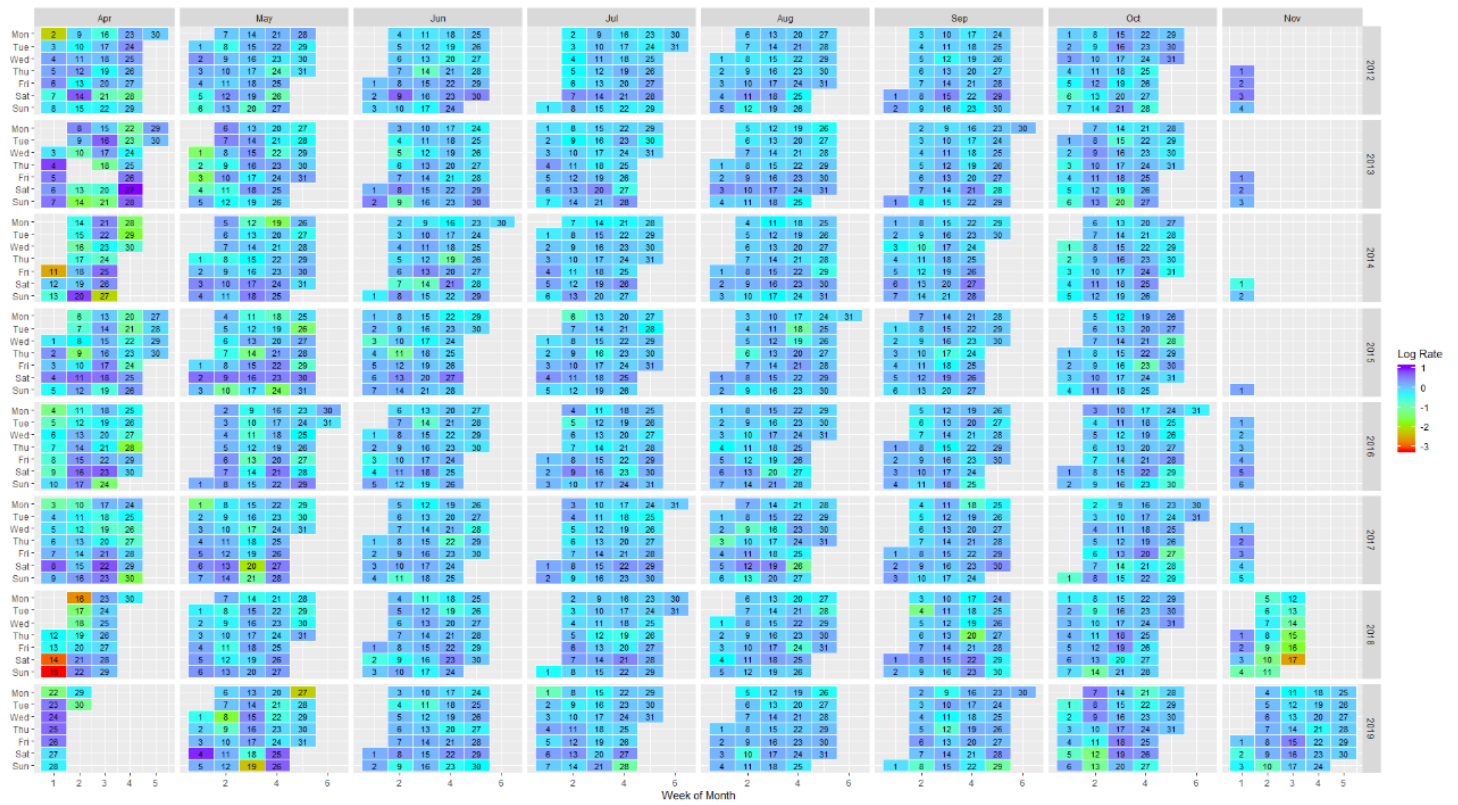

Figure B.1: Nice Ride Calendar Heatmap for Total Ridership - Log (Ratio of Daily Total Ridership to 14 Day Moving Average Total Ridership)

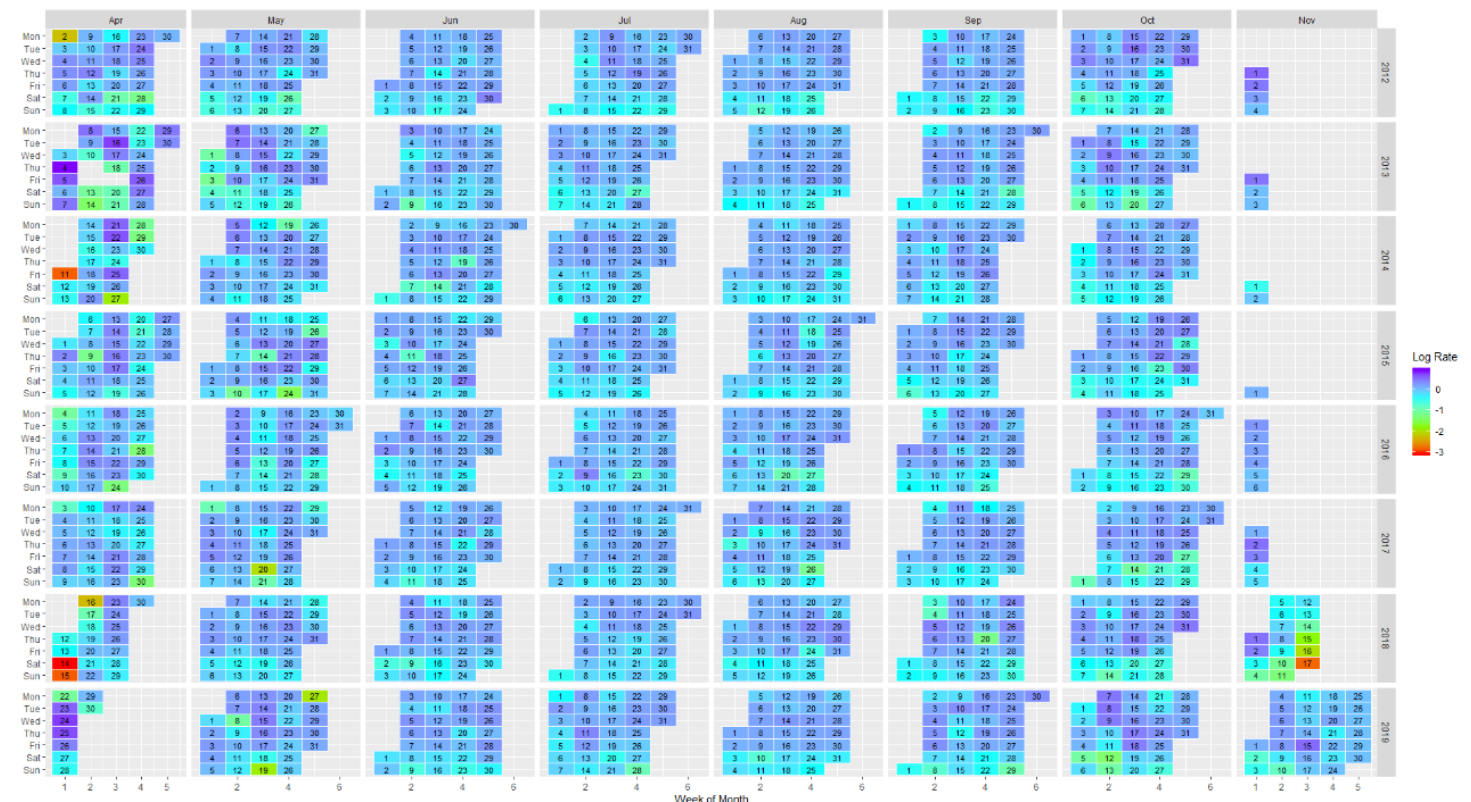

Figure B.2: Nice Ride Calendar Heatmap for Member Ridership - Log (Ratio of Daily Member Ridership to 14 Day Moving Average Member Ridership) 


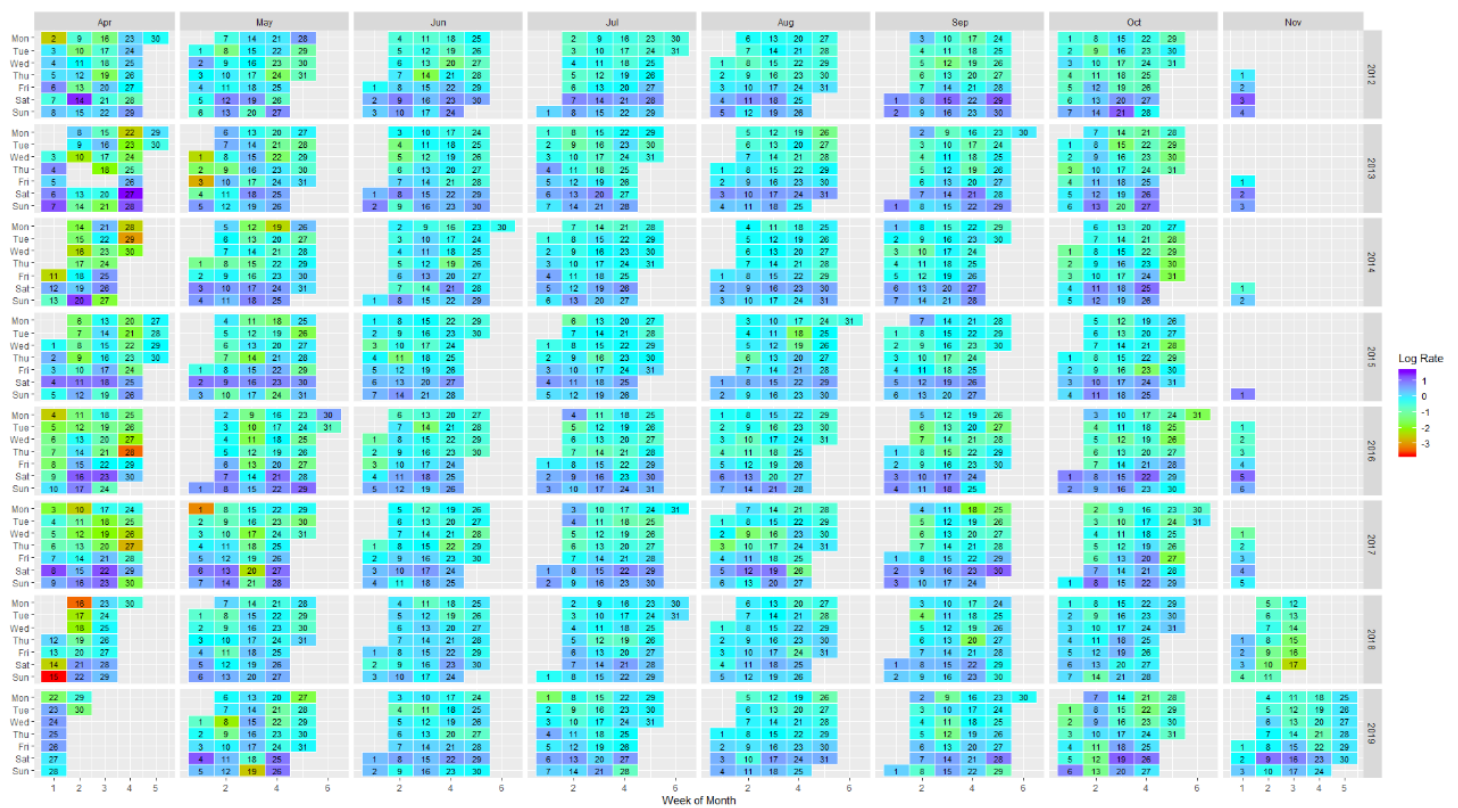

Figure B.3: Nice Ride Calendar Heatmap for Non-Member Ridership - Log (Ratio of Daily Non-Member Ridership to 14 Day Moving Average Non-Member Ridership)

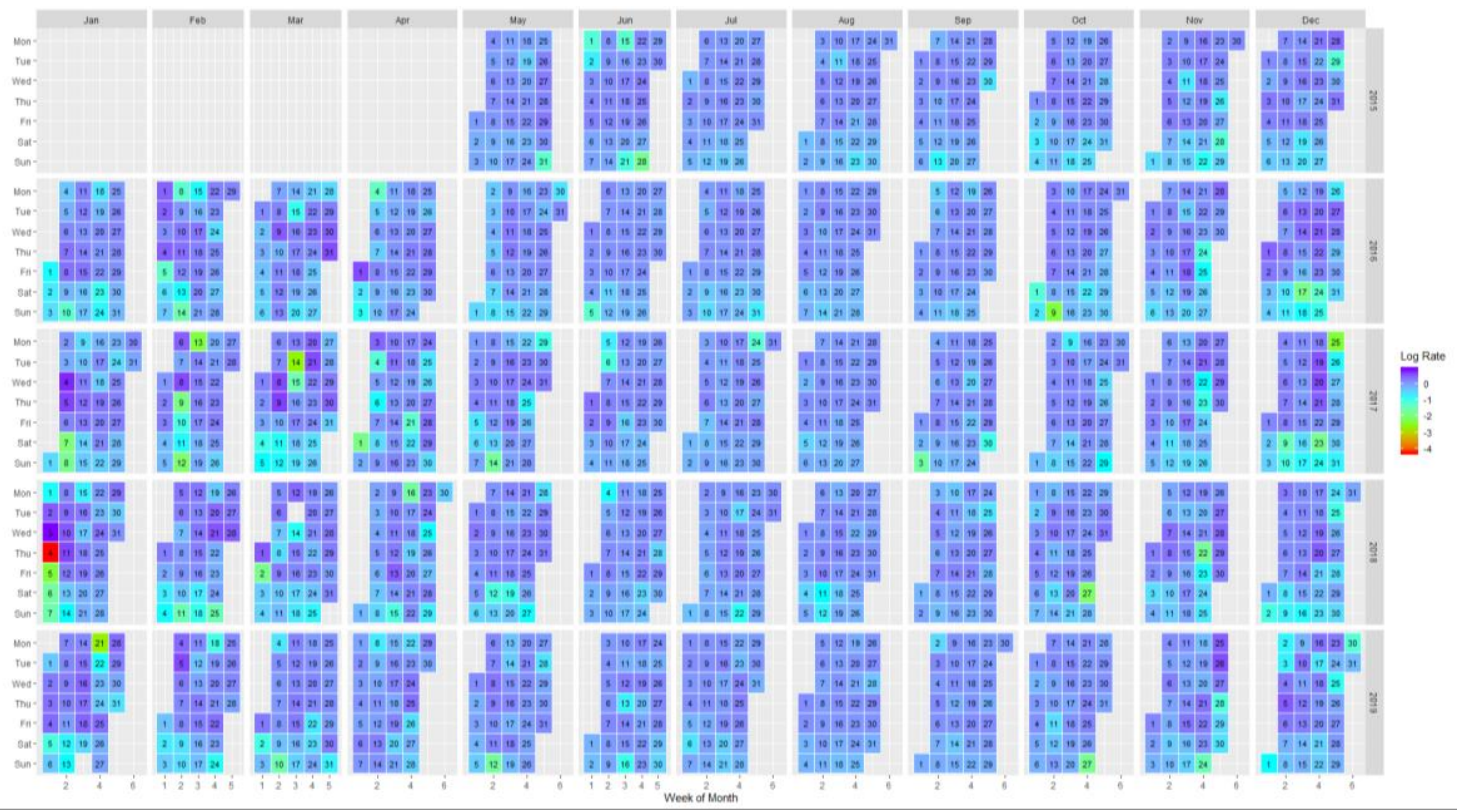

Figure B.4: Bluebike Calendar Heatmap for Total Ridership - Log (Ratio of Daily Total Ridership to 14 Day Moving Average Total Ridership) 


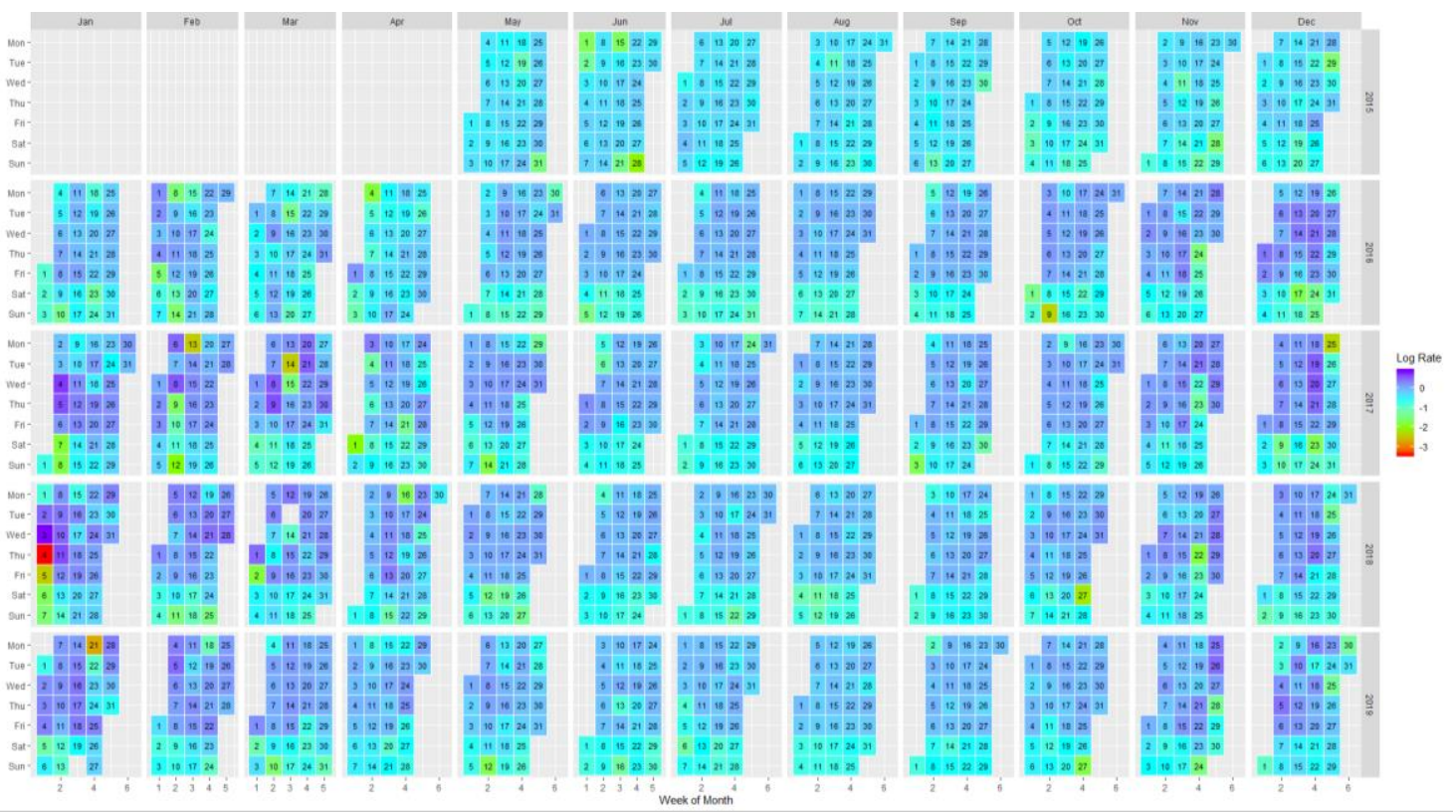

Figure B.5: Bluebike Calendar Heatmap for Member Ridership - Log (Ratio of Daily Member Ridership to 14 Day Moving Average Member Ridership)

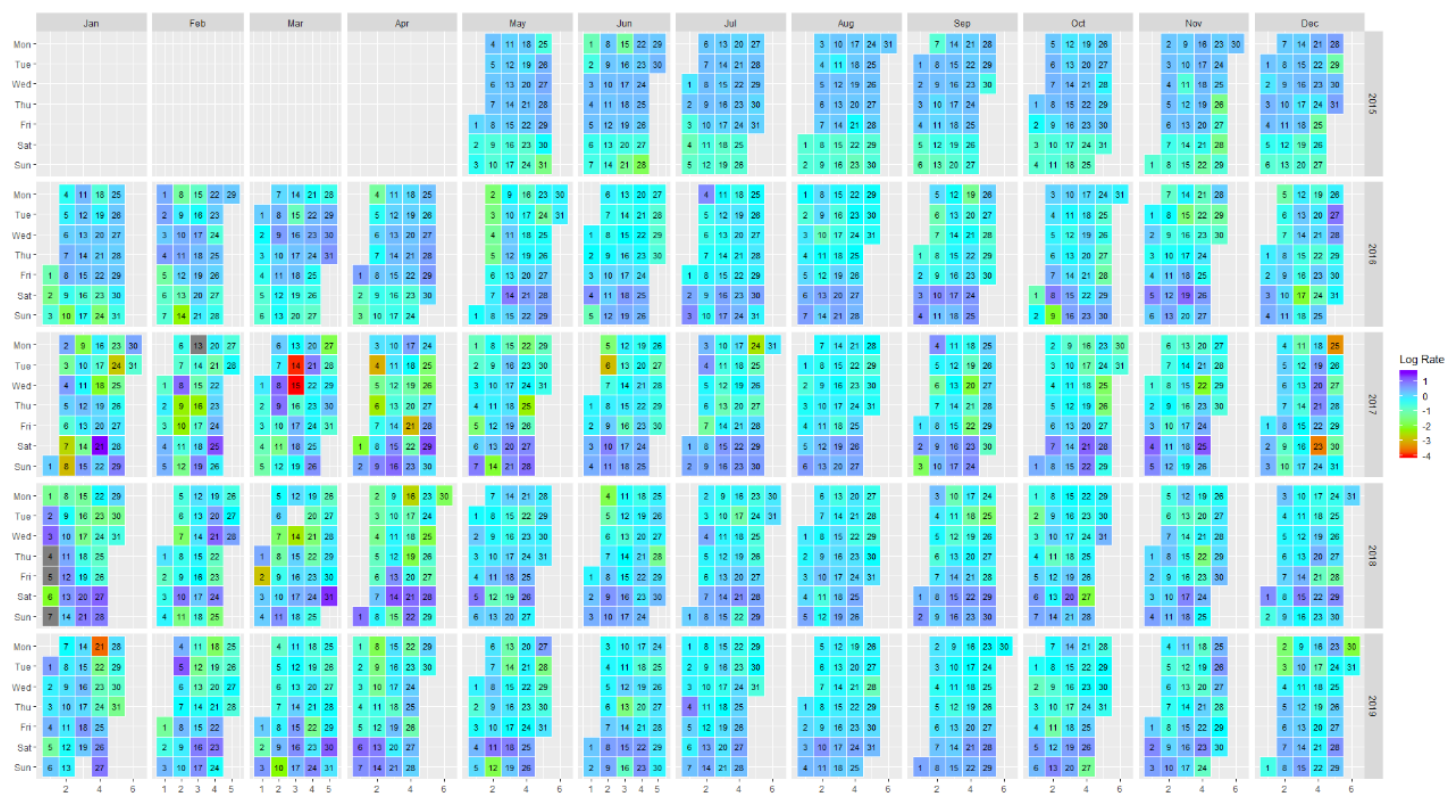

Figure B.6: Bluebike Calendar Heatmap for Non-Member Ridership - Log (Ratio of Daily Non-Member Ridership to 14 Day Moving Average Member Ridership) 


\section{Appendix C: Hypotheses Models - Members}

Table C.1: Federal Holidays Grouped Plus Weekend Variable

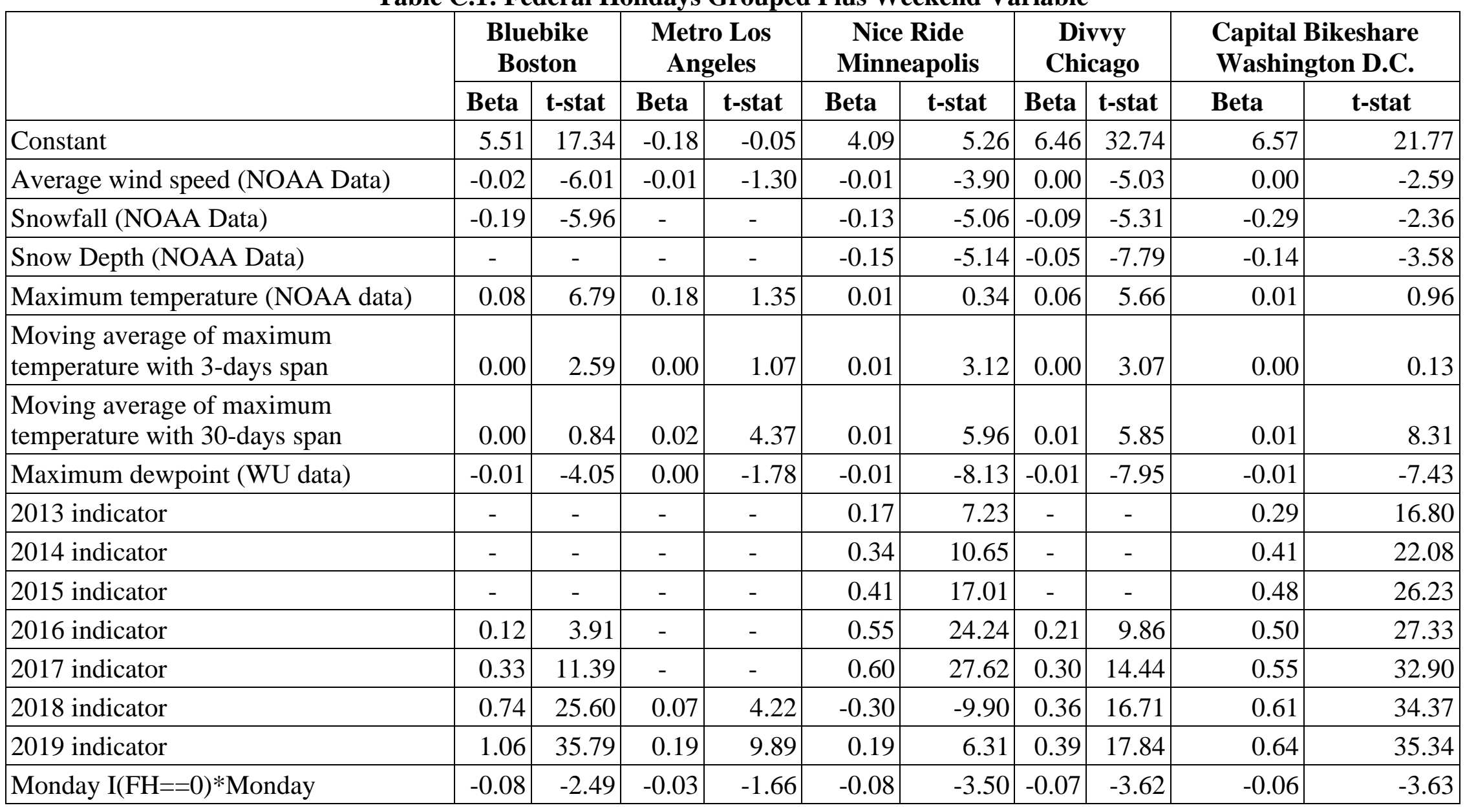


Table C.1 (Continued)

\begin{tabular}{|c|c|c|c|c|c|c|c|c|c|c|}
\hline Tuesday & -0.03 & -1.11 & 0.01 & 0.38 & 0.00 & -0.18 & 0.00 & 0.24 & 0.01 & 0.66 \\
\hline Thursday & 0.00 & 0.02 & 0.02 & 1.22 & -0.02 & -0.67 & -0.01 & -0.50 & 0.01 & 0.43 \\
\hline Friday & -0.08 & -2.60 & -0.03 & -1.56 & -0.05 & -1.89 & -0.07 & -3.70 & -0.02 & -1.26 \\
\hline Weekend Indicator & -0.59 & -22.05 & -0.45 & -19.99 & -0.43 & -21.50 & -0.67 & -38.60 & -0.40 & -28.78 \\
\hline January indicator & -1.14 & -9.68 & -0.08 & -1.70 & - & - & -0.14 & -1.90 & 0.19 & 3.46 \\
\hline February indicator & -1.02 & -8.74 & -0.02 & -0.44 & - & - & -0.07 & -0.98 & 0.21 & 4.05 \\
\hline March indicator & -0.79 & -7.91 & 0.04 & 0.67 & - & - & -0.17 & -2.78 & 0.17 & 3.50 \\
\hline April indicator & -0.39 & -4.74 & -0.10 & -2.00 & -0.10 & -1.61 & -0.21 & -4.22 & 0.14 & 4.14 \\
\hline May indicator & -0.13 & -2.18 & -0.01 & -0.13 & -0.05 & -1.36 & -0.06 & -1.82 & 0.10 & 4.39 \\
\hline June indicator & -0.05 & -1.30 & 0.08 & 2.95 & 0.02 & 0.92 & 0.02 & 0.78 & 0.08 & 5.19 \\
\hline August indicator & -0.02 & -0.61 & 0.11 & 4.50 & -0.10 & -6.96 & 0.01 & 0.73 & -0.02 & -1.46 \\
\hline September indicator & 0.10 & 3.76 & 0.10 & 3.44 & -0.06 & -3.22 & 0.01 & 0.51 & 0.06 & 4.29 \\
\hline October indicator & 0.09 & 2.25 & 0.11 & 3.01 & 0.01 & 0.43 & 0.04 & 1.45 & 0.16 & 7.40 \\
\hline November indicator & -0.07 & -1.14 & -0.02 & -0.47 & -0.26 & -3.26 & -0.06 & -1.40 & 0.17 & 4.87 \\
\hline December indicator & -0.58 & -5.84 & -0.06 & -1.22 & - & -1 & -0.23 & -3.33 & 0.06 & 1.23 \\
\hline Federal holidays indicator & -0.72 & -8.54 & -0.48 & -6.71 & -0.42 & -5.50 & -0.73 & -7.74 & -0.63 & -10.27 \\
\hline Cherry Blossom Festival Saturday & - & - & - & - & - & - & - & - & 0.16 & 3.91 \\
\hline Cherry Blossom Festival Weekday & - & 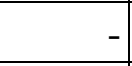 & - & - & - & - & 4 & - & 0.02 & 1.47 \\
\hline $\begin{array}{l}\text { Quadratic effects of maximum } \\
\text { temperature (NOAA Data) }\end{array}$ & 0.00 & -3.82 & 0.00 & -1.11 & 0.00 & 1.20 & 0.00 & -2.17 & 0.00 & 1.64 \\
\hline $\begin{array}{l}\text { Cubic effects of maximum temperature } \\
\text { (NOAA Data) }\end{array}$ & 0.00 & 2.00 & 0.00 & 0.87 & 0.00 & -2.17 & 0.00 & 0.82 & 0.00 & -3.09 \\
\hline $\mathrm{I}(\mathrm{PRCP}>0 \& \mathrm{SNOW}==0)$ & -0.07 & -3.11 & 0.00 & 0.05 & -0.07 & -3.72 & -0.10 & -5.48 & -0.03 & -2.43 \\
\hline $\mathrm{I}(\mathrm{PRCP}>0 \& \mathrm{SNOW}==0) * \mathrm{PRCP}$ & -0.65 & -8.04 & -1.31 & -5.12 & -0.31 & -5.52 & -0.29 & -6.06 & -0.54 & -9.64 \\
\hline $\mathrm{I}(\mathrm{PRCP}>0$ \& SNOW $==0) * \mathrm{PRCP}^{\wedge} 2$ & 0.16 & 3.59 & 0.69 & 4.13 & 0.04 & 1.72 & 0.01 & 0.78 & 0.10 & 3.51 \\
\hline $\mathrm{I}(\mathrm{SNOW}>0)$ & -0.04 & -0.49 & -1 & - & -0.14 & -1.08 & -0.01 & -0.14 & -0.02 & -0.18 \\
\hline
\end{tabular}


Table C.1 (Continued)

\begin{tabular}{|l|c|c|c|c|c|}
\hline Number of Observation & 1704.00 & 975.00 & 1727.00 & 1791.00 & 2876.00 \\
\hline R-Squared & 0.86 & 0.65 & 0.85 & 0.89 & 0.79 \\
\hline Adjusted R-Squared & 0.86 & 0.63 & 0.85 & 0.89 & 0.78 \\
\hline Durbin Watson's Test & 0.69 & 0.76 & 1.08 & 1.27 & 1.34 \\
\hline MAPE & 0.28 & 0.17 & 0.21 & 0.19 & 0.19 \\
\hline AIC & 1314.56 & -141.00 & 455.00 & 313.73 & 123.06 \\
\hline
\end{tabular}

Table C.2: Federal Holidays Grouped and Saturday and Sunday Separately

\begin{tabular}{|c|c|c|c|c|c|c|c|c|c|c|}
\hline & \multicolumn{2}{|c|}{$\begin{array}{c}\text { Bluebike } \\
\text { Boston }\end{array}$} & \multicolumn{2}{|c|}{$\begin{array}{c}\text { Metro Los } \\
\text { Angeles }\end{array}$} & \multicolumn{2}{|c|}{$\begin{array}{c}\text { Nice Ride } \\
\text { Minneapolis }\end{array}$} & \multicolumn{2}{|c|}{$\begin{array}{c}\text { Divvy } \\
\text { Chicago }\end{array}$} & \multicolumn{2}{|c|}{$\begin{array}{l}\text { Capital Bikeshare } \\
\text { Washington D.C. }\end{array}$} \\
\hline & Beta & t-stat & Beta & t-stat & Beta & t-stat & Beta & t-stat & Beta & t-stat \\
\hline Constant & 5.49 & 17.34 & -0.38 & -0.11 & 4.09 & 5.20 & 6.47 & 32.56 & 6.60 & 22.06 \\
\hline Average wind speed (NOAA Data) & -0.02 & -5.94 & -0.01 & -1.33 & -0.01 & -3.80 & 0.00 & -5.14 & 0.00 & -2.69 \\
\hline Snowfall (NOAA Data) & -0.19 & -6.14 & - & - & -0.13 & -4.95 & -0.08 & -5.39 & -0.29 & -2.32 \\
\hline Snow Depth (NOAA Data) & - & - & - & - & -0.15 & -5.07 & -0.05 & -7.90 & -0.14 & -3.61 \\
\hline Maximum temperature (NOAA data) & 0.08 & 6.85 & 0.18 & 1.40 & 0.01 & 0.32 & 0.06 & 5.52 & 0.01 & 0.89 \\
\hline $\begin{array}{l}\text { Moving average of maximum } \\
\text { temperature with 3-days span }\end{array}$ & 0.00 & 2.50 & 0.00 & 1.16 & 0.01 & 3.10 & 0.00 & 3.02 & 0.00 & -0.01 \\
\hline $\begin{array}{l}\text { Moving average of maximum } \\
\text { temperature with } 30 \text {-days span }\end{array}$ & 0.00 & 0.91 & 0.02 & 4.36 & 0.01 & 5.97 & 0.01 & 5.93 & 0.01 & 8.42 \\
\hline Maximum dewpoint (WU data) & -0.01 & -4.10 & 0.00 & -1.81 & -0.01 & -8.21 & -0.01 & -7.92 & -0.01 & -7.42 \\
\hline 2013 indicator & - & - & - & - & 0.17 & 7.28 & - & - & 0.29 & 17.00 \\
\hline 2014 indicator & - & - & - & - & 0.34 & 10.68 & - & - & 0.41 & 22.09 \\
\hline 2015 indicator & - & - & - & - & 0.41 & 17.13 & - & - & 0.48 & 26.37 \\
\hline 2016 indicator & 0.12 & 3.92 & - & - & 0.55 & 24.23 & 0.21 & 9.95 & 0.50 & 27.46 \\
\hline 2017 indicator & 0.33 & 11.42 & - & - & 0.60 & 27.69 & 0.30 & 14.62 & 0.55 & 33.28 \\
\hline 2018 indicator & 0.74 & 25.61 & 0.07 & 4.21 & -0.30 & -9.88 & 0.37 & 16.94 & 0.61 & 34.72 \\
\hline
\end{tabular}


Table C.2 (Continued)

\begin{tabular}{|c|c|c|c|c|c|c|c|c|c|c|}
\hline & & & & & & & & & & \\
\hline 2019 indicator & 1.06 & 35.85 & 0.19 & 9.88 & 0.19 & 6.32 & 0.39 & 17.88 & 0.64 & 35.78 \\
\hline Monday & -0.05 & -1.63 & -0.02 & -1.06 & -0.08 & -3.24 & -0.06 & -2.64 & -0.04 & -2.48 \\
\hline Tuesday & -0.03 & -1.07 & -0.01 & -0.53 & 0.00 & -0.17 & -0.01 & -0.59 & 0.00 & 0.14 \\
\hline Thursday & -0.01 & -0.41 & 0.01 & 0.64 & -0.02 & -0.95 & -0.04 & -1.90 & -0.01 & -0.57 \\
\hline Friday & -0.07 & -2.19 & -0.03 & -1.61 & -0.05 & -1.93 & -0.08 & -3.97 & -0.02 & -1.51 \\
\hline Saturday & -0.53 & -16.90 & -0.43 & -17.04 & -0.40 & -17.09 & -0.61 & -29.25 & -0.33 & -20.92 \\
\hline Sunday & -0.64 & -20.63 & -0.48 & -14.97 & -0.46 & -20.02 & -0.74 & -32.54 & -0.47 & -28.41 \\
\hline January indicator & -1.13 & -9.60 & -0.07 & -1.66 & - & - & -0.13 & -1.79 & 0.20 & 3.56 \\
\hline February indicator & -1.02 & -8.68 & -0.02 & -0.43 & - & - & -0.06 & -0.88 & 0.21 & 4.16 \\
\hline March indicator & -0.78 & -7.85 & 0.04 & 0.67 & - & - & -0.16 & -2.66 & 0.17 & 3.72 \\
\hline April indicator & -0.38 & -4.69 & -0.10 & -2.00 & -0.10 & -1.57 & -0.20 & -4.13 & 0.15 & 4.51 \\
\hline May indicator & -0.12 & -2.11 & 0.00 & -0.10 & -0.05 & -1.30 & -0.06 & -1.70 & 0.10 & 4.55 \\
\hline June indicator & -0.05 & -1.27 & 0.08 & 2.96 & 0.02 & 0.96 & 0.02 & 0.82 & 0.08 & 5.30 \\
\hline August indicator & -0.02 & -0.62 & 0.11 & 4.54 & -0.10 & -6.95 & 0.01 & 0.70 & -0.02 & -1.58 \\
\hline September indicator & 0.10 & 3.85 & 0.10 & 3.45 & -0.06 & -3.17 & 0.01 & 0.59 & 0.07 & 4.49 \\
\hline October indicator & 0.09 & 2.33 & 0.11 & 3.03 & 0.02 & 0.52 & 0.04 & 1.61 & 0.16 & 7.62 \\
\hline November indicator & -0.07 & -1.09 & -0.02 & -0.50 & -0.25 & -3.21 & -0.06 & -1.29 & 0.17 & 5.00 \\
\hline December indicator & -0.57 & -5.77 & -0.06 & -1.22 & - & - & -0.22 & -3.22 & 0.06 & 1.29 \\
\hline Federal Holidays Indicator & -0.67 & -7.75 & -0.47 & -6.42 & -0.36 & -4.64 & -0.69 & -7.22 & -0.61 & -9.71 \\
\hline Cherry Blossom Festival Saturday & & - & - & - & - & - & - & - & 0.09 & 2.06 \\
\hline Cherry Blossom Festival Weekday & - & - & - & -1 & - & - & - & - & 0.02 & 1.11 \\
\hline $\begin{array}{l}\text { Quadratic effects of maximum } \\
\text { temperature (NOAA Data) }\end{array}$ & 0.00 & -3.83 & 0.00 & -1.16 & 0.00 & 1.22 & 0.00 & -2.06 & 0.00 & 1.75 \\
\hline $\begin{array}{l}\text { Cubic effects of maximum } \\
\text { temperature (NOAA Data) }\end{array}$ & 0.00 & 2.00 & 0.00 & 0.92 & 0.00 & -2.19 & 0.00 & 0.74 & 0.00 & -3.21 \\
\hline $\mathrm{I}(\mathrm{PRCP}>0 \& \mathrm{SNOW}==0)$ & -0.07 & -3.11 & 0.01 & 0.22 & -0.07 & -3.73 & -0.10 & -5.46 & -0.04 & -2.65 \\
\hline
\end{tabular}


Table C.2 (Continued)

\begin{tabular}{|c|c|c|c|c|c|c|c|c|c|c|}
\hline $\mathrm{I}(\mathrm{PRCP}>0 \& \mathrm{SNOW}==0) * \mathrm{PRCP}$ & -0.65 & -8.06 & -1.35 & -5.20 & -0.31 & -5.51 & -0.29 & -5.96 & -0.54 & -9.48 \\
\hline $\begin{array}{l}\mathrm{I}(\mathrm{PRCP}>0 \text { \& } \mathrm{SNOW}==0) * \\
\mathrm{PRCP}^{\wedge} 2\end{array}$ & 0.16 & 3.61 & 0.71 & 4.21 & 0.04 & 1.73 & 0.01 & 0.63 & 0.10 & 3.30 \\
\hline $\mathrm{I}(\mathrm{SNOW}>0)$ & -0.04 & -0.43 & - & - & -0.13 & -1.05 & -0.01 & -0.15 & -0.03 & -0.26 \\
\hline Number of Observation & \multicolumn{2}{|c|}{1704.00} & \multicolumn{2}{|r|}{975.00} & \multicolumn{2}{|r|}{1727.00} & \multicolumn{2}{|c|}{1790.00} & \multicolumn{2}{|r|}{2875.00} \\
\hline R-Squared & \multicolumn{2}{|r|}{0.86} & \multicolumn{2}{|r|}{0.45} & \multicolumn{2}{|r|}{0.85} & \multicolumn{2}{|r|}{0.89} & \multicolumn{2}{|r|}{0.79} \\
\hline Adjusted R-Squared & \multicolumn{2}{|r|}{$0 . .8554$} & \multicolumn{2}{|r|}{0.63} & \multicolumn{2}{|r|}{0.85} & \multicolumn{2}{|r|}{0.89} & \multicolumn{2}{|r|}{0.79} \\
\hline Durbin Watson's Test & \multicolumn{2}{|r|}{0.68} & \multicolumn{2}{|r|}{0.75} & \multicolumn{2}{|r|}{1.07} & \multicolumn{2}{|r|}{1.22} & \multicolumn{2}{|r|}{1.30} \\
\hline MAPE & \multicolumn{2}{|r|}{0.28} & \multicolumn{2}{|r|}{0.16} & \multicolumn{2}{|r|}{0.21} & \multicolumn{2}{|r|}{0.19} & \multicolumn{2}{|r|}{0.19} \\
\hline AIC & \multicolumn{2}{|c|}{1311.37} & \multicolumn{2}{|r|}{-138.00} & \multicolumn{2}{|r|}{450.00} & \multicolumn{2}{|r|}{281.01} & \multicolumn{2}{|r|}{75.11} \\
\hline
\end{tabular}

Table C.3: Non-Work Holidays Grouped by Business Closure Rate

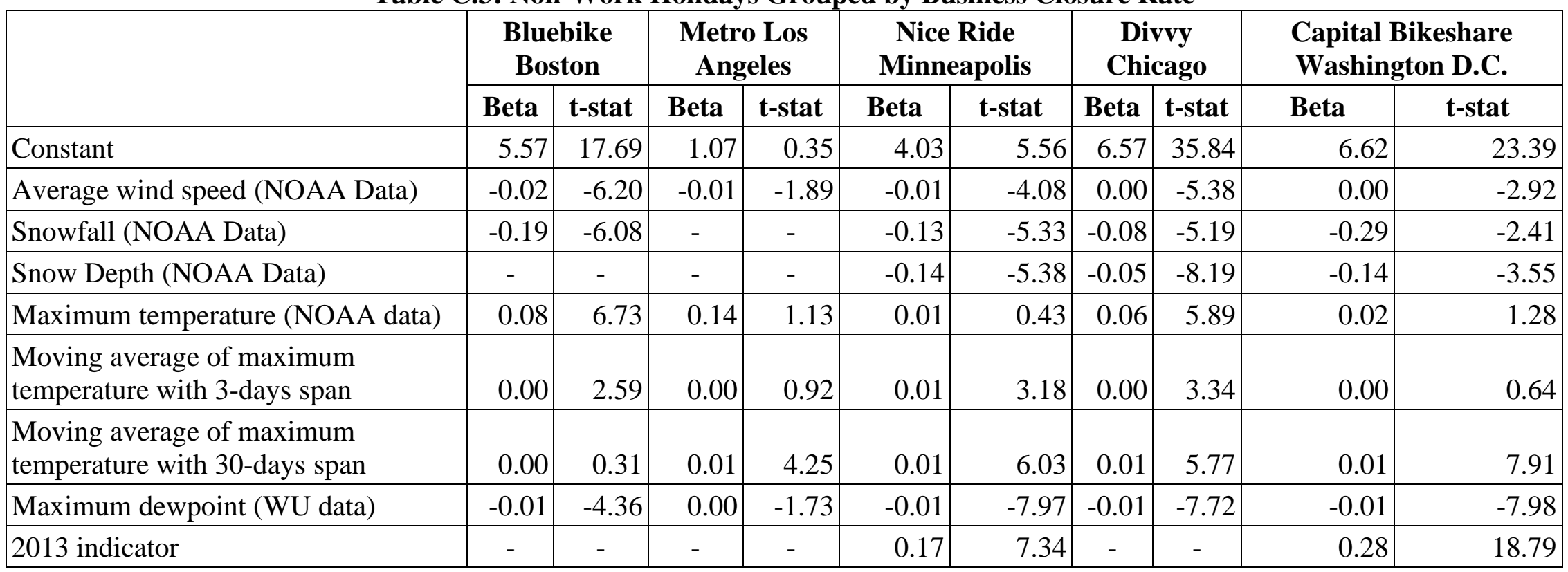


Table C.3 (Continued)

\begin{tabular}{|c|c|c|c|c|c|c|c|c|c|c|}
\hline \\
\hline 2014 indicator & - & - & - & - & 0.34 & 10.71 & - & - & 0.40 & 23.78 \\
\hline 2015 indicator & - & - & - & - & 0.41 & 17.11 & - & - & 0.48 & 28.78 \\
\hline 2016 indicator & 0.12 & 4.23 & - & - & 0.55 & 24.23 & 0.22 & 11.54 & 0.50 & 30.68 \\
\hline 2017 indicator & 0.34 & 11.78 & - & - & 0.60 & 27.92 & 0.30 & 16.25 & 0.55 & 37.61 \\
\hline 2018 indicator & 0.74 & 26.28 & 0.07 & 4.32 & -0.30 & -10.03 & 0.36 & 18.31 & 0.61 & 37.93 \\
\hline 2019 indicator & 1.06 & 36.67 & 0.18 & 9.84 & 0.19 & 6.40 & 0.39 & 19.28 & 0.64 & 38.22 \\
\hline Monday & -0.05 & -1.67 & -0.03 & -1.32 & -0.07 & -3.06 & -0.05 & -2.74 & -0.04 & -2.83 \\
\hline Tuesday & -0.03 & -0.91 & 0.00 & -0.22 & 0.00 & -0.16 & 0.00 & 0.16 & 0.01 & 0.63 \\
\hline Thursday & 0.00 & -0.04 & 0.02 & 0.77 & -0.02 & -0.91 & -0.02 & -1.24 & 0.00 & -0.14 \\
\hline Friday & -0.05 & -1.55 & -0.03 & -1.28 & -0.05 & -1.88 & -0.06 & -3.29 & -0.01 & -0.53 \\
\hline Saturday & -0.53 & -17.05 & -0.43 & -16.94 & -0.40 & -17.11 & -0.60 & -30.61 & -0.33 & -22.09 \\
\hline Sunday & -0.63 & -20.70 & -0.47 & -14.83 & -0.46 & -20.39 & -0.73 & -35.25 & -0.46 & -30.02 \\
\hline January indicator & -1.19 & -10.49 & -0.09 & -2.18 & - & - & -0.19 & -2.94 & 0.15 & 2.93 \\
\hline February indicator & -1.08 & -9.63 & -0.05 & -1.08 & - & - & -0.15 & -2.33 & 0.14 & 3.13 \\
\hline March indicator & -0.83 & -8.67 & 0.02 & 0.39 & - & - & -0.22 & -3.98 & 0.13 & 2.97 \\
\hline April indicator & -0.42 & -5.37 & -0.11 & -2.09 & -0.09 & -1.45 & -0.24 & -5.26 & 0.12 & 3.94 \\
\hline May indicator & -0.14 & -2.49 & 0.00 & -0.08 & -0.03 & -0.89 & -0.07 & -2.07 & 0.10 & 4.32 \\
\hline June indicator & -0.06 & -1.67 & 0.08 & 2.85 & 0.02 & 1.07 & 0.01 & 0.30 & 0.07 & 4.77 \\
\hline August indicator & -0.01 & -0.50 & 0.12 & 4.67 & -0.10 & -6.87 & 0.01 & 0.65 & -0.02 & -1.65 \\
\hline September indicator & 0.11 & 4.15 & 0.11 & 3.81 & -0.04 & -2.38 & 0.02 & 1.04 & 0.08 & 4.69 \\
\hline October indicator & 0.07 & 1.78 & 0.10 & 2.87 & 0.01 & 0.34 & 0.02 & 0.85 & 0.14 & 6.76 \\
\hline November indicator & -0.07 & -1.19 & -0.01 & -0.21 & -0.23 & -2.95 & -0.07 & -1.62 & 0.16 & 5.12 \\
\hline December indicator & -0.57 & -6.01 & -0.05 & -1.06 & 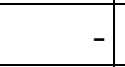 & 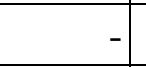 & -0.21 & -3.51 & 0.06 & 1.42 \\
\hline $\begin{array}{l}\text { Non-work Holidays Indicator } \\
\text { (including observed and actual } \\
\text { weekday holiday) }\end{array}$ & -0.96 & -8.08 & -0.68 & -6.46 & -0.63 & -5.10 & -1.17 & -10.12 & -1.01 & -12.67 \\
\hline
\end{tabular}


Table C.3 (Continued)

\begin{tabular}{|c|c|c|c|c|c|c|c|c|c|c|}
\hline $\begin{array}{l}\text { Mostly-work Holidays Indicator } \\
\text { (including observed and actual } \\
\text { weekday holiday) }\end{array}$ & -0.87 & -11.66 & -0.44 & -5.43 & -0.36 & -4.40 & -0.84 & -12.07 & -0.71 & -12.56 \\
\hline $\begin{array}{l}\text { Barely-work Holidays Indicator } \\
\text { (including observed and actual } \\
\text { weekday holiday) }\end{array}$ & -0.31 & -3.88 & -0.17 & -3.17 & 0.00 & -0.06 & -0.20 & -3.10 & -0.18 & -5.68 \\
\hline New Year*Weekend & -0.15 & -2.77 & - & - & - & - & -0.65 & -19.59 & -0.66 & -29.02 \\
\hline Christmas*Weekend & -1.17 & -24.12 & - & - & - & - & -1.62 & -43.19 & -1.35 & -48.87 \\
\hline Independence* weekend & 0.62 & 14.61 & - & - & -0.05 & -1.97 & -0.06 & -2.47 & -0.01 & -0.16 \\
\hline Veterans*weekend & -0.06 & -1.33 & -0.11 & -0.52 & -1.42 & -10.80 & -0.08 & -1.74 & 0.10 & 3.21 \\
\hline Cherry Blossom Festival Saturday & - & - & - & - & - & - & - & - & 0.09 & 2.18 \\
\hline Cherry Blossom Festival Weekday & - & - & - & - & - & - & - & - & 0.02 & 1.34 \\
\hline $\begin{array}{l}\text { Quadratic effects of maximum } \\
\text { temperature (NOAA Data) }\end{array}$ & 0.00 & -3.89 & 0.00 & -0.89 & 0.00 & 1.21 & 0.00 & -2.34 & 0.00 & 1.37 \\
\hline $\begin{array}{l}\text { Cubic effects of maximum } \\
\text { temperature (NOAA Data) }\end{array}$ & 0.00 & 2.17 & 0.00 & 0.65 & 0.00 & -2.24 & 0.00 & 0.99 & 0.00 & -2.83 \\
\hline $\mathrm{I}(\mathrm{PRCP}>0$ \& SNOW ==0) & -0.06 & -2.93 & 0.02 & 0.42 & -0.07 & -3.72 & -0.10 & -6.22 & -0.05 & -3.58 \\
\hline $\mathrm{I}(\mathrm{PRCP}>0 \& \mathrm{SNOW}==0) * \mathrm{PRCP}$ & -0.66 & -8.22 & -1.35 & -5.41 & -0.32 & -5.63 & -0.30 & -6.57 & -0.54 & -9.63 \\
\hline $\begin{array}{l}\mathrm{I}(\mathrm{PRCP}>0 \text { \& } \mathrm{SNOW}==0) * \\
\mathrm{PRCP}^{\wedge} 2\end{array}$ & 0.17 & 3.71 & 0.72 & 4.38 & 0.05 & 1.78 & 0.02 & 0.83 & 0.10 & 3.36 \\
\hline $\mathrm{I}(\mathrm{SNOW}>0)$ & -0.06 & -0.78 & - & - & -0.14 & -1.15 & -0.04 & -0.92 & -0.06 & -0.50 \\
\hline Number of Observation & \multicolumn{2}{|c|}{1704.00} & \multicolumn{2}{|c|}{975.00} & \multicolumn{2}{|c|}{1727.00} & \multicolumn{2}{|c|}{\begin{tabular}{|l|}
1784.00 \\
\end{tabular}} & \multicolumn{2}{|c|}{2870.00} \\
\hline R-Squared & \multicolumn{2}{|c|}{0.87} & \multicolumn{2}{|c|}{0.66} & \multicolumn{2}{|c|}{0.86} & \multicolumn{2}{|c|}{0.91} & \multicolumn{2}{|c|}{0.82} \\
\hline Adjusted R-Squared & \multicolumn{2}{|c|}{0.87} & \multicolumn{2}{|c|}{0.65} & \multicolumn{2}{|c|}{0.85} & \multicolumn{2}{|c|}{0.91} & \multicolumn{2}{|c|}{0.82} \\
\hline Durbin Watson's Test & \multicolumn{2}{|c|}{0.77} & \multicolumn{2}{|c|}{0.76} & \multicolumn{2}{|c|}{1.09} & \multicolumn{2}{|c|}{1.40} & \multicolumn{2}{|c|}{1.50} \\
\hline MAPE & \multicolumn{2}{|c|}{0.27} & \multicolumn{2}{|c|}{0.16} & \multicolumn{2}{|c|}{0.21} & \multicolumn{2}{|c|}{0.17} & \multicolumn{2}{|c|}{0.17} \\
\hline AIC & \multicolumn{2}{|c|}{1191.00} & \multicolumn{2}{|c|}{-183.00} & \multicolumn{2}{|c|}{388.00} & \multicolumn{2}{|c|}{-104.57} & \multicolumn{2}{|c|}{-397.30} \\
\hline
\end{tabular}


Table C.4: Holiday-Specific Effects with Additional Grouped by Saturday and Sunday Before Monday Federal Holidays

\begin{tabular}{|c|c|c|c|c|c|c|c|c|c|c|}
\hline & \multicolumn{2}{|c|}{$\begin{array}{l}\text { Capital Bikeshare } \\
\text { Washington D.C. }\end{array}$} & \multicolumn{2}{|c|}{$\begin{array}{l}\text { Bluebike } \\
\text { Boston }\end{array}$} & \multicolumn{2}{|c|}{$\begin{array}{l}\text { Divvy } \\
\text { Chicago }\end{array}$} & \multicolumn{2}{|c|}{$\begin{array}{c}\text { Nice Ride } \\
\text { Minneapolis }\end{array}$} & \multicolumn{2}{|c|}{$\begin{array}{l}\text { Metro Los } \\
\text { Angeles }\end{array}$} \\
\hline & Beta & t-stat & Beta & t-stat & Beta & t-stat & Beta & t-stat & Beta & t-stat \\
\hline Constant & 6.73 & 24.23 & 5.77 & 18.30 & 6.66 & 35.96 & 3.62 & 4.11 & -5.99 & -1.77 \\
\hline Average wind speed (NOAA Data) & 0.00 & -2.87 & -0.02 & -6.36 & 0.00 & -5.82 & -0.01 & -3.98 & -0.02 & -3.10 \\
\hline Snowfall (NOAA Data) & -0.29 & -2.41 & -0.19 & -5.92 & -0.08 & -4.73 & -0.16 & -4.81 & - & - \\
\hline Snow Depth (NOAA Data) & -0.14 & -3.56 & - & - & -0.05 & -8.46 & - & - & - & - \\
\hline Maximum temperature (NOAA data) & 0.01 & 1.14 & 0.08 & 6.48 & 0.06 & 5.59 & 0.03 & 0.62 & 0.40 & 3.07 \\
\hline $\begin{array}{l}\text { Moving average of maximum } \\
\text { temperature with 3-days span }\end{array}$ & 0.00 & 1.17 & 0.01 & 2.89 & 0.00 & 3.33 & 0.01 & 3.79 & 0.00 & 0.47 \\
\hline $\begin{array}{l}\text { Moving average of maximum } \\
\text { temperature with } 30 \text {-days span }\end{array}$ & 0.01 & 7.20 & 0.00 & -0.24 & 0.01 & 5.30 & 0.01 & 6.15 & 0.02 & 4.68 \\
\hline Maximum dewpoint (WU data) & -0.01 & -8.29 & -0.01 & -4.29 & -0.01 & -8.23 & -0.01 & -7.67 & -0.01 & -4.09 \\
\hline 2013 indicator & 0.28 & 19.63 & - & - & - & - & 0.16 & 7.07 & - & - \\
\hline 2014 indicator & 0.40 & 24.90 & - & - & - & - & 0.34 & 10.90 & - & - \\
\hline 2015 indicator & 0.48 & 30.23 & - & - & - & - & 0.41 & 17.56 & - & - \\
\hline 2016 indicator & 0.50 & 32.14 & 0.13 & 4.40 & 0.22 & 12.05 & 0.55 & 24.48 & - & - \\
\hline 2017 indicator & 0.55 & 40.10 & 0.33 & 11.96 & 0.30 & 17.16 & 0.60 & 27.71 & - & - \\
\hline 2018 indicator & 0.60 & 39.92 & 0.74 & 26.69 & 0.36 & 19.05 & -0.32 & -10.91 & 0.07 & 4.07 \\
\hline 2019 indicator & 0.64 & 39.81 & 1.06 & 37.49 & 0.39 & 19.93 & 0.19 & 6.62 & 0.17 & 8.73 \\
\hline Monday & -0.06 & -4.50 & -0.07 & -2.26 & -0.08 & -4.34 & -0.08 & -3.29 & -0.04 & -1.82 \\
\hline Tuesday & 0.01 & 0.69 & -0.03 & -0.89 & 0.00 & 0.29 & 0.00 & -0.21 & 0.00 & 0.00 \\
\hline Thursday & 0.00 & 0.28 & 0.01 & 0.35 & -0.01 & -0.58 & -0.01 & -0.47 & 0.01 & 0.64 \\
\hline Friday & -0.01 & -0.74 & -0.06 & -1.81 & -0.06 & -3.26 & -0.04 & -1.49 & -0.02 & -0.91 \\
\hline Saturday & -0.32 & -21.42 & -0.53 & -16.66 & -0.60 & -29.31 & -0.39 & -15.50 & -0.44 & -15.49 \\
\hline Sunday & -0.45 & -28.68 & -0.62 & -20.51 & -0.72 & -34.37 & -0.45 & -18.95 & -0.48 & -15.00 \\
\hline
\end{tabular}


Table C.4 (Continued)

\begin{tabular}{|c|c|c|c|c|c|c|c|c|c|c|}
\hline & & & & & & & & & & \\
\hline January indicator & 0.13 & 2.53 & -1.24 & -10.79 & -0.23 & -3.58 & - & & -0.19 & -3.71 \\
\hline February indicator & 0.12 & 2.70 & -1.13 & -9.94 & -0.18 & -3.03 & - & & -0.07 & -1.36 \\
\hline March indicator & 0.10 & 2.40 & -0.88 & -9.18 & -0.25 & -4.84 & - & & -0.02 & -0.26 \\
\hline April indicator & 0.11 & 3.47 & -0.46 & -5.89 & -0.27 & -6.14 & -0.08 & -1.19 & -0.12 & -2.28 \\
\hline May indicator & 0.08 & 3.79 & -0.17 & -3.05 & -0.11 & -3.51 & 0.00 & 0.10 & -0.04 & -1.01 \\
\hline \begin{tabular}{|l} 
June indicator \\
\end{tabular} & 0.08 & 5.10 & -0.07 & -1.86 & 0.01 & 0.27 & 0.03 & 1.56 & 0.07 & 2.40 \\
\hline August indicator & -0.01 & -0.63 & 0.00 & -0.08 & 0.02 & 1.01 & -0.09 & -6.46 & 0.11 & 4.48 \\
\hline September indicator & 0.07 & 4.77 & 0.10 & 4.07 & 0.01 & 0.33 & -0.03 & -1.73 & 0.09 & 2.85 \\
\hline October indicator & 0.14 & 6.96 & 0.07 & 1.72 & 0.01 & 0.27 & 0.06 & 1.69 & 0.05 & 1.55 \\
\hline November indicator & 0.16 & 5.24 & -0.08 & -1.35 & -0.07 & -1.86 & -0.12 & -1.42 & -0.05 & -1.55 \\
\hline December indicator & 0.07 & 1.65 & -0.58 & -6.08 & -0.21 & -3.60 & - & - & -0.13 & -2.90 \\
\hline $\begin{array}{l}\text { New Year's Day (actual days, } \\
\text { including weekend) }\end{array}$ & -1.13 & -16.61 & -0.88 & -5.05 & -1.38 & -23.36 & - & & -0.87 & -3.61 \\
\hline $\begin{array}{l}\text { New Year's Day Observed (only } \\
\text { observed days, Friday or Monday) }\end{array}$ & -0.90 & -8.82 & -0.33 & -5.86 & -0.73 & -22.17 & - & & - & - \\
\hline New Year's Day*Weekend & 0.46 & 7.00 & 0.73 & 4.25 & 0.71 & 11.09 & - & & - & - \\
\hline New Year's Eve & -0.33 & -4.81 & -0.67 & -4.21 & -0.56 & -4.60 & - & & -0.10 & -0.50 \\
\hline Thanksgiving Day & -1.43 & -37.68 & -1.50 & -24.52 & -1.74 & -47.98 & -3.10 & -18.99 & -1.09 & -5.49 \\
\hline Day After Thanksgiving & -0.85 & -28.37 & -0.98 & -15.43 & -1.03 & -10.71 & -1.59 & -11.91 & -0.49 & -2.71 \\
\hline Christmas Day & -1.76 & -24.96 & -1.63 & -6.20 & -1.98 & -31.79 & - & & -0.97 & -6.95 \\
\hline Christmas Day Observed & -1.17 & -41.41 & -1.25 & -22.39 & -0.97 & -22.55 & - & & - & - \\
\hline Christmas Day*Weekend & 0.37 & 5.41 & 0.41 & 1.58 & 0.30 & 4.91 & - & & - & - \\
\hline Christmas Eve & -0.96 & -16.55 & -1.03 & -13.50 & -0.98 & -10.30 & - & & -0.25 & -2.72 \\
\hline Martin Luther King's Day & -0.24 & -1.72 & -0.50 & -2.07 & -0.08 & -0.37 & - & & 0.08 & 0.60 \\
\hline Memorial Day & -0.46 & -14.53 & -0.51 & -2.72 & -0.44 & -11.79 & -0.62 & -4.21 & -0.31 & -2.14 \\
\hline President Day & -0.18 & -2.47 & -0.35 & -1.25 & -0.21 & -3.80 & - & & -0.27 & -3.88 \\
\hline
\end{tabular}


Table C.4 (Continued)

\begin{tabular}{|c|c|c|c|c|c|c|c|c|c|c|}
\hline Independence Day & -0.36 & -8.16 & -0.82 & -7.76 & -0.64 & \begin{tabular}{|l|}
-11.41 \\
\end{tabular} & -0.28 & -3.80 & -0.47 & -3.64 \\
\hline Independence Day Observed & -0.38 & -17.46 & 0.00 & -0.03 & -0.33 & -12.76 & -0.41 & -15.23 & - & - \\
\hline Independence Day*Weekend & 0.35 & 6.55 & 1.43 & 12.94 & 0.58 & 9.63 & 0.22 & 2.89 & - & - \\
\hline Labor Day & -0.42 & -10.21 & -0.42 & -5.03 & -0.59 & -5.91 & -0.45 & -4.80 & -0.45 & -2.62 \\
\hline Columbus Day & -0.18 & -4.30 & -0.33 & -4.51 & -0.04 & -0.94 & 0.00 & 0.04 & -0.10 & -3.19 \\
\hline Veterans Day & -0.11 & -1.84 & -0.09 & -1.08 & -0.15 & -0.56 & 0.67 & 2.03 & -0.03 & -0.78 \\
\hline Veterans Day Observed & -0.02 & -0.87 & -0.04 & -0.42 & 0.12 & 4.51 & -0.46 & -1.89 & -0.28 & -2.22 \\
\hline Veterans Day*Weekend & 0.13 & 1.69 & 0.01 & 0.14 & -0.06 & -0.20 & -2.23 & -10.84 & -0.09 & -0.39 \\
\hline Good Friday & -0.09 & -2.31 & -0.01 & -0.10 & -0.16 & -1.62 & -0.06 & -0.69 & -0.01 & -0.08 \\
\hline Saturday Before Monday Holidays & -0.13 & -3.68 & -0.05 & -0.61 & -0.03 & -0.63 & -0.14 & -3.53 & 0.10 & 1.91 \\
\hline \begin{tabular}{|l} 
Sunday Before Monday Holidays \\
\end{tabular} & -0.09 & -2.66 & -0.09 & -0.91 & -0.04 & -0.76 & -0.15 & -2.87 & 0.13 & 1.00 \\
\hline Cherry Blossom Festival Saturday & 0.08 & 1.94 & 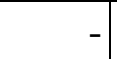 & - & & - & - & & - & - \\
\hline Cherry Blossom Festival Weekday & 0.02 & 1.36 & - & - & - & - & - & & - & - \\
\hline $\begin{array}{l}\text { Quadratic effects of maximum } \\
\text { temperature (NOAA Data) }\end{array}$ & 0.00 & 1.54 & 0.00 & -3.61 & 0.00 & -2.07 & 0.00 & 0.74 & 0.00 & -2.71 \\
\hline $\begin{array}{l}\text { Cubic effects of maximum } \\
\text { temperature (NOAA Data) }\end{array}$ & 0.00 & -3.06 & 0.00 & 1.86 & 0.00 & 0.70 & 0.00 & -1.62 & 0.00 & 2.36 \\
\hline $\mathrm{I}(\mathrm{PRCP}>0$ \& $\mathrm{SNOW}==0)$ & -0.05 & -4.11 & -0.06 & -2.88 & -0.09 & -6.30 & -0.07 & -3.83 & - & - \\
\hline $\mathrm{I}(\mathrm{PRCP}>0$ \& SNOW $==0) * \mathrm{PRCP}$ & -0.53 & -9.37 & -0.68 & -8.62 & -0.30 & -6.81 & -0.32 & -5.71 & - & - \\
\hline $\begin{array}{l}\mathrm{I}(\mathrm{PRCP}>0 \& \mathrm{SNOW}==0) * \\
\mathrm{PRCP}^{\wedge} 2\end{array}$ & 0.09 & 3.24 & 0.18 & 3.96 & 0.02 & 0.85 & 0.05 & 1.79 & - & - \\
\hline $\mathrm{I}(\mathrm{SNOW}>0)$ & -0.06 & -0.52 & -0.06 & -0.75 & -0.04 & -1.03 & -0.25 & -1.82 & - & - \\
\hline \begin{tabular}{|l|} 
Number of Observation \\
\end{tabular} & \multicolumn{2}{|c|}{$2,853.00$} & \multicolumn{2}{|c|}{$1,646.00$} & \multicolumn{2}{|c|}{$1,767.00$} & \multicolumn{2}{|c|}{$1,680.00$} & \multicolumn{2}{|c|}{930.00} \\
\hline \begin{tabular}{|l} 
R-Squared \\
\end{tabular} & \multicolumn{2}{|c|}{0.84} & \multicolumn{2}{|c|}{0.87} & \multicolumn{2}{|c|}{0.92} & \multicolumn{2}{|c|}{0.85} & \multicolumn{2}{|c|}{0.64} \\
\hline Adjusted R-Squared & \multicolumn{2}{|c|}{0.83} & \multicolumn{2}{|c|}{0.87} & \multicolumn{2}{|c|}{0.92} & \multicolumn{2}{|c|}{0.85} & \multicolumn{2}{|c|}{0.62} \\
\hline Durbin Watson's Test & \multicolumn{2}{|c|}{1.57} & \multicolumn{2}{|c|}{0.77} & \multicolumn{2}{|c|}{1.46} & \multicolumn{2}{|c|}{1.09} & \multicolumn{2}{|c|}{0.89} \\
\hline
\end{tabular}


Table C.4 (Continued)

\begin{tabular}{|l|c|c|c|c|c|}
\hline MAPE & 0.16 & 0.26 & 0.16 & 0.20 & 0.17 \\
\hline AIC & -633.76 & $1,151.24$ & -268.62 & 422.13 & -88.24 \\
\hline
\end{tabular}

Table C.5: Holiday-Specific Effects with Additional Individual Saturday and Sunday Before Monday Federal Holidays

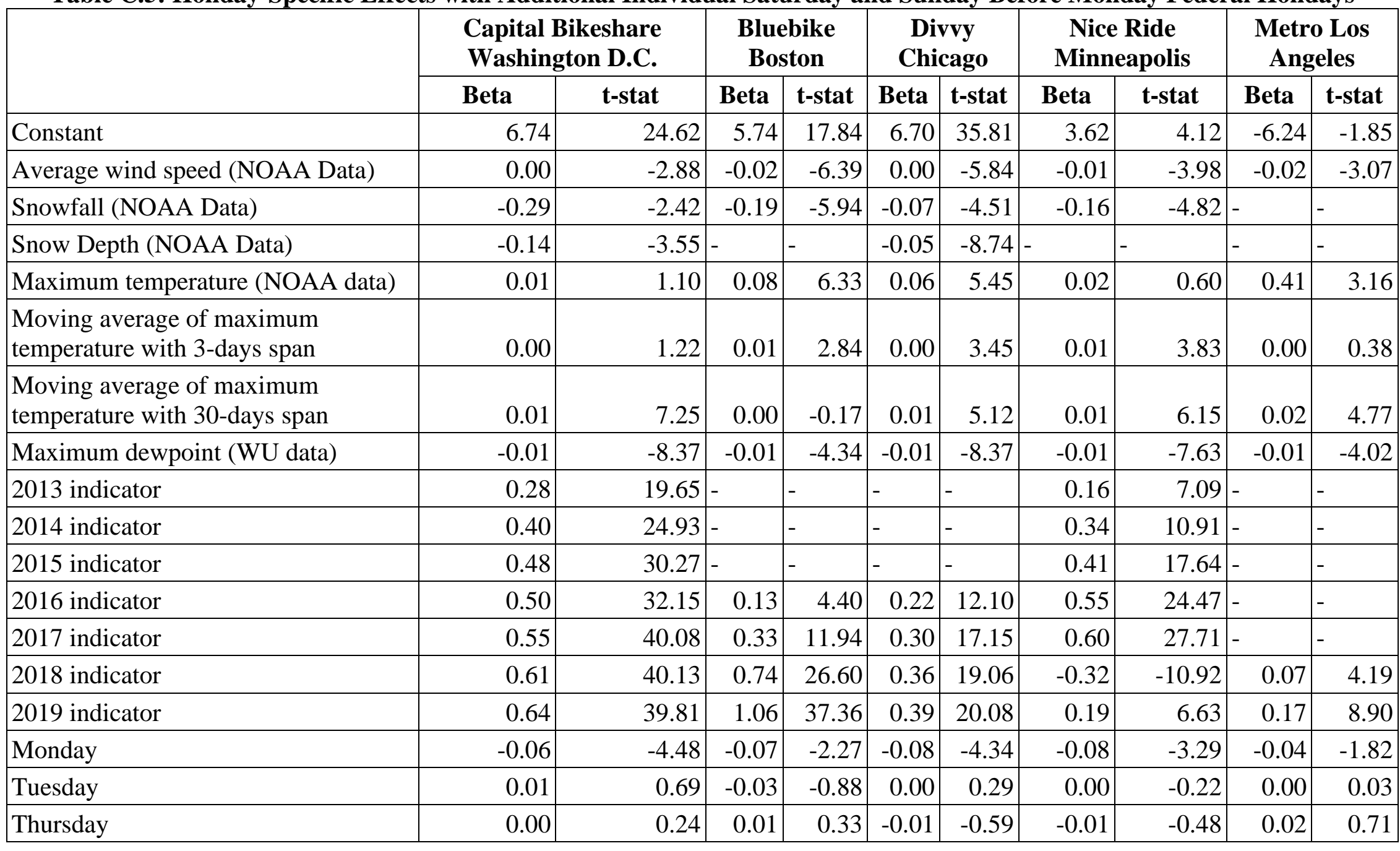


Table C.5 (Continued)

\begin{tabular}{|c|c|c|c|c|c|c|c|c|c|c|}
\hline \\
\hline Friday & -0.01 & -0.75 & -0.06 & -1.82 & -0.06 & -3.30 & -0.04 & -1.49 & -0.02 & -0.87 \\
\hline Saturday & -0.32 & -21.27 & -0.53 & -16.62 & -0.59 & -29.73 & -0.39 & -15.46 & -0.44 & -15.22 \\
\hline Sunday & -0.45 & -28.50 & -0.62 & -20.49 & -0.72 & -34.03 & -0.45 & -18.95 & -0.48 & -14.90 \\
\hline January indicator & 0.13 & 2.51 & -1.24 & -10.75 & -0.24 & -3.69 & - & - & -0.19 & -3.58 \\
\hline February indicator & 0.13 & 2.83 & -1.13 & -9.95 & -0.18 & -2.96 & - & - & -0.06 & -1.29 \\
\hline March indicator & 0.10 & 2.42 & -0.87 & -9.15 & -0.27 & -5.11 & - & - & -0.01 & -0.25 \\
\hline April indicator & 0.11 & 3.50 & -0.46 & -5.86 & -0.28 & -6.42 & -0.07 & -1.15 & -0.12 & -2.27 \\
\hline May indicator & 0.09 & 4.01 & -0.17 & -3.04 & -0.12 & -4.00 & 0.01 & 0.25 & -0.04 & -0.99 \\
\hline June indicator & 0.08 & 5.12 & -0.06 & -1.83 & 0.00 & 0.15 & 0.03 & 1.60 & 0.07 & 2.43 \\
\hline August indicator & -0.01 & -0.63 & 0.00 & -0.06 & 0.02 & 1.04 & -0.09 & -6.42 & 0.11 & 4.47 \\
\hline September indicator & 0.07 & 4.97 & 0.11 & 4.48 & 0.00 & 0.24 & -0.03 & -1.73 & 0.09 & 2.96 \\
\hline October indicator & 0.14 & 6.73 & 0.07 & 1.79 & -0.01 & -0.23 & 0.06 & 1.66 & 0.04 & 1.27 \\
\hline November indicator & 0.16 & 5.30 & -0.08 & -1.32 & -0.08 & -2.14 & -0.11 & -1.40 & -0.05 & -1.56 \\
\hline December indicator & 0.07 & 1.68 & -0.57 & -6.04 & -0.23 & -3.84 & - & - & -0.13 & -2.88 \\
\hline $\begin{array}{l}\text { New Year's Day (actual days, } \\
\text { including weekend) }\end{array}$ & -1.13 & -16.39 & -0.88 & -4.96 & -1.39 & -24.03 & - & - & -0.87 & -3.66 \\
\hline New Year's Day Observed & -0.90 & -8.83 & -0.33 & -5.60 & -0.75 & -22.41 & - & - & - & - \\
\hline New Year's Day*Weekend & 0.46 & 6.95 & 0.73 & 4.20 & 0.71 & 11.25 & - & - & - & - \\
\hline New Year's Eve & -0.33 & -4.80 & -0.67 & -4.18 & -0.56 & -4.63 & - & - & -0.10 & -0.50 \\
\hline Thanksgiving Day & -1.42 & -37.69 & -1.50 & -24.60 & -1.74 & -47.79 & -3.11 & -18.99 & -1.09 & -5.52 \\
\hline Day After Thanksgiving & -0.85 & -28.38 & -0.98 & -15.40 & -1.03 & -10.77 & -1.59 & -11.91 & -0.50 & -2.71 \\
\hline Christmas Day & -1.76 & -25.01 & -1.63 & -6.20 & -1.97 & -30.92 & - & - & -0.98 & -6.96 \\
\hline Christmas Day Observed & -1.16 & -41.35 & -1.25 & -22.38 & -0.97 & -22.59 & - & - & - & - \\
\hline Christmas Day*Weekend & 0.37 & 5.41 & 0.41 & 1.58 & 0.30 & 4.75 & - & - & - & - \\
\hline Christmas Eve & -0.96 & -16.59 & -1.02 & -13.49 & -0.98 & -10.24 & - & - & -0.25 & -2.73 \\
\hline Martin Luther King's Day & -0.24 & -1.71 & -0.49 & -2.02 & -0.09 & -0.44 & - & - & 0.08 & 0.58 \\
\hline
\end{tabular}


Table C.5 (Continued)

\begin{tabular}{|c|c|c|c|c|c|c|c|c|c|c|}
\hline Memorial Day & -0.46 & -14.62 & -0.51 & -2.71 & -0.43 & -11.55 & -0.63 & -4.25 & -0.31 & -2.15 \\
\hline President Day & -0.19 & -2.54 & -0.35 & -1.22 & -0.23 & -4.15 & & - & -0.27 & -3.86 \\
\hline Independence Day & -0.36 & -8.17 & -0.82 & -7.78 & -0.64 & -11.45 & -0.28 & -3.79 & -0.47 & -3.64 \\
\hline Independence Day Observed & -0.38 & -17.49 & 0.00 & -0.01 & -0.33 & -12.94 & -0.41 & -15.19 & - & \\
\hline Independence Day*Weekend & 0.35 & 6.53 & 1.43 & 13.00 & 0.57 & 9.52 & 0.22 & 2.88 & - & \\
\hline Labor Day & -0.42 & -10.27 & -0.43 & -5.14 & -0.59 & -5.84 & -0.45 & -4.79 & -0.46 & -2.71 \\
\hline Columbus Day & -0.17 & -4.16 & -0.33 & -4.55 & -0.03 & -0.72 & 0.01 & 0.08 & -0.09 & -2.99 \\
\hline Veterans Day & -0.11 & -1.83 & -0.09 & -1.08 & -0.15 & -0.55 & 0.66 & 2.01 & -0.03 & -0.75 \\
\hline Veterans Day Observed & -0.02 & -0.87 & -0.05 & -0.44 & 0.12 & 4.51 & -0.46 & -1.91 & -0.28 & -2.24 \\
\hline Veterans Day*Weekend & 0.13 & 1.66 & 0.01 & 0.11 & -0.06 & -0.22 & -2.22 & -10.79 & -0.08 & -0.38 \\
\hline Good Friday & -0.09 & -2.30 & -0.01 & -0.09 & -0.15 & -1.58 & 1 & - & -0.01 & -0.09 \\
\hline Saturday Before Presidents Day & -0.21 & -2.82 & -0.01 & -0.02 & -0.18 & -1.63 & - & - & 0.03 & 0.69 \\
\hline Sunday Before Presidents Day & -0.13 & -1.32 & 0.07 & 0.27 & -0.36 & -2.04 & 4 & - & 0.12 & 0.63 \\
\hline Saturday Before Memorial Day & -0.22 & -6.94 & -0.08 & -0.56 & 0.09 & 2.60 & - & - & 0.17 & 1.05 \\
\hline Sunday Before Memorial Day & -0.14 & -2.27 & -0.04 & -0.21 & 0.09 & 1.86 & & - & 0.03 & 0.10 \\
\hline Saturday Before Labor Day & -0.11 & -1.06 & -0.21 & -1.81 & -0.09 & -0.97 & -0.06 & -0.69 & 0.06 & 0.52 \\
\hline Sunday Before Labor Day & -0.12 & -2.24 & -0.20 & -1.09 & 0.01 & 0.12 & -0.14 & -2.02 & 0.03 & 0.20 \\
\hline Saturday Before Columbus Day & -0.07 & -1.30 & -0.04 & -0.54 & -0.01 & -0.15 & -0.26 & -2.11 & 0.07 & 0.90 \\
\hline Sunday Before Columbus Day & 0.01 & 0.25 & -0.15 & -0.95 & 0.14 & 2.76 & -0.16 & -2.11 & 0.47 & 1.32 \\
\hline Saturday Before MLK Day & -0.11 & -1.08 & 0.13 & 0.78 & -0.33 & -1.61 & -0.10 & -1.69 & 0.11 & 1.17 \\
\hline \begin{tabular}{|l} 
Sunday Before MLK Day \\
\end{tabular} & -0.10 & -1.47 & -0.12 & -0.68 & -0.15 & -1.82 & -0.13 & -3.32 & -0.01 & -0.04 \\
\hline Cherry Blossom Festival Saturday & 0.08 & 1.90 & & - & - & - & & & - & \\
\hline Cherry Blossom Festival Weekday & 0.02 & 1.40 & 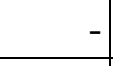 & - & - & - & -0.08 & -2.97 & - & \\
\hline $\begin{array}{l}\text { Quadratic effects of maximum } \\
\text { temperature (NOAA Data) }\end{array}$ & 0.00 & 1.62 & 0.00 & -3.55 & 0.00 & -1.99 & 0.00 & 0.75 & 0.00 & -2.82 \\
\hline
\end{tabular}


Table C.5 (Continued)

\begin{tabular}{|c|c|c|c|c|c|c|c|c|c|c|}
\hline $\begin{array}{l}\text { Cubic effects of maximum } \\
\text { temperature (NOAA Data) }\end{array}$ & 0.00 & -3.17 & 0.00 & 1.86 & 0.00 & 0.64 & 0.00 & -1.62 & 0.00 & 2.49 \\
\hline $\mathrm{I}(\mathrm{PRCP}>0$ \& SNOW == 0) & -0.05 & -4.04 & -0.06 & -2.85 & -0.09 & -6.07 & -0.07 & -3.82 & - & - \\
\hline $\mathrm{I}(\mathrm{PRCP}>0$ \& SNOW $==0) * \mathrm{PRCP}$ & -0.53 & -9.37 & -0.69 & -8.68 & -0.31 & -6.85 & -0.32 & -5.74 & - & - \\
\hline $\begin{array}{l}\mathrm{I}(\mathrm{PRCP}>0 \text { \& } \mathrm{SNOW}==0) * \\
\mathrm{PRCP}^{\wedge} 2\end{array}$ & 0.09 & 3.24 & 0.18 & 4.05 & 0.02 & 0.87 & 0.05 & 1.82 & -1 & \\
\hline $\mathrm{I}(\mathrm{SNOW}>0)$ & -0.06 & -0.48 & -0.06 & -0.76 & -0.04 & -0.96 & -0.25 & -1.83 & - & \\
\hline Number of Observation & \multicolumn{2}{|c|}{$2,845.00$} & \multicolumn{2}{|c|}{$1,638.00$} & \multicolumn{2}{|c|}{$1,759.00$} & \multicolumn{2}{|c|}{$1,676.00$} & \multicolumn{2}{|c|}{922.00} \\
\hline R-Squared & \multicolumn{2}{|c|}{0.84} & \multicolumn{2}{|c|}{0.87} & \multicolumn{2}{|c|}{0.92} & \multicolumn{2}{|c|}{0.85} & \multicolumn{2}{|c|}{0.64} \\
\hline Adjusted R-Squared & \multicolumn{2}{|c|}{0.83} & \multicolumn{2}{|c|}{0.87} & \multicolumn{2}{|c|}{0.92} & \multicolumn{2}{|c|}{0.85} & \multicolumn{2}{|c|}{0.62} \\
\hline Durbin Watson's Test & \multicolumn{2}{|c|}{1.58} & \multicolumn{2}{|c|}{0.77} & \multicolumn{2}{|c|}{1.45} & \multicolumn{2}{|c|}{1.09} & \multicolumn{2}{|c|}{0.87} \\
\hline MAPE & \multicolumn{2}{|c|}{0.16} & \multicolumn{2}{|c|}{0.26} & \multicolumn{2}{|c|}{0.16} & \multicolumn{2}{|c|}{0.20} & \multicolumn{2}{|c|}{0.17} \\
\hline AIC & \multicolumn{2}{|c|}{-626.79} & \multicolumn{2}{|c|}{$1,162.82$} & \multicolumn{2}{|c|}{-284.12} & \multicolumn{2}{|c|}{427.54} & \multicolumn{2}{|c|}{-81.60} \\
\hline
\end{tabular}

Table C.6: Member Special Event Model

\begin{tabular}{|c|c|c|c|c|c|c|c|c|c|c|}
\hline \multirow[t]{2}{*}{ Variable Description } & \multicolumn{2}{|c|}{$\begin{array}{l}\text { Capital Bikeshare } \\
\text { Washington D.C. }\end{array}$} & \multicolumn{2}{|c|}{$\begin{array}{c}\text { Divvy } \\
\text { Chicago }\end{array}$} & \multicolumn{2}{|c|}{$\begin{array}{l}\text { Bluebike } \\
\text { Boston }\end{array}$} & \multicolumn{2}{|c|}{$\begin{array}{c}\text { Nice Ride } \\
\text { Minneapolis }\end{array}$} & \multicolumn{2}{|c|}{$\begin{array}{c}\text { Metro Bikeshare } \\
\text { Los Angeles }\end{array}$} \\
\hline & Mean & t-stat & Mean & t-stat & Mean & t-stat & Mean & t-stat & Mean & t-stat \\
\hline Constant & 6.46 & 30.31 & 5.74 & 18.55 & 6.62 & 37.03 & 4.03 & 4.68 & 0.96 & 0.34 \\
\hline $\begin{array}{l}\text { New Year's Day (actual } \\
\text { days, including weekend) }\end{array}$ & -1.09 & -17.92 & -0.86 & -4.92 & -1.37 & -21.57 & - & - & -0.91 & -4.21 \\
\hline $\begin{array}{l}\text { New Year's Day Observed } \\
\text { (only observed days, } \\
\text { Friday or Monday) }\end{array}$ & -0.87 & -8.71 & -0.31 & -5.62 & -0.74 & -21.97 & - & - & - & - \\
\hline
\end{tabular}


Table C.6 (Continued)

\begin{tabular}{|c|c|c|c|c|c|c|c|c|c|c|}
\hline $\begin{array}{l}\text { New Year's } \\
\text { Day*Weekend }\end{array}$ & 0.46 & 7.46 & 0.72 & 4.20 & 0.73 & 10.77 & - & - & - & - \\
\hline New Year's Eve & -0.33 & -5.12 & -0.68 & -4.17 & -0.57 & -4.58 & - & - & -0.14 & -0.70 \\
\hline Thanksgiving Day & -1.45 & -39.72 & -1.5 & -24.48 & -1.75 & -50.89 & -2.31 & -10.79 & -0.88 & -7.79 \\
\hline Day After Thanksgiving & -0.86 & -30.37 & -0.99 & -16.27 & -1.03 & -10.58 & -1.07 & -7.12 & -0.55 & -3.3 \\
\hline Christmas Day & -1.77 & -25.60 & -1.63 & -6.25 & -2.01 & -25.53 & - & - & -0.89 & -3.45 \\
\hline Christmas Day Observed & -1.19 & -44.68 & -1.26 & -22.68 & -1.01 & -24.29 & - & - & - & - \\
\hline Christmas Day*Weekend & 0.38 & 5.59 & 0.41 & 1.58 & 0.34 & 4.26 & - & - & - & - \\
\hline Christmas Eve & -0.97 & -16.59 & -1.04 & -13.76 & -0.99 & -10.98 & - & - & -0.32 & -3.5 \\
\hline Martin Luther King's Day & -0.26 & -2.39 & -0.54 & -2.51 & -0.10 & -0.51 & - & - & -0.11 & -0.70 \\
\hline Memorial Day & -0.45 & -14.02 & -0.50 & -2.64 & -0.45 & -12.79 & -0.60 & -4.05 & -0.32 & -2.23 \\
\hline President Day & -0.19 & -3.42 & -0.39 & -1.44 & -0.22 & -3.89 & - & - & -0.36 & -6.53 \\
\hline Independence Day & -0.37 & -8.24 & -0.82 & -7.67 & -0.64 & -11.43 & -0.28 & -4.04 & -0.47 & -3.61 \\
\hline $\begin{array}{l}\text { Independence Day } \\
\text { Observed }\end{array}$ & -0.37 & -18.81 & -0.01 & -0.14 & -0.33 & -13.24 & -0.42 & -15.5 & - & - \\
\hline $\begin{array}{l}\text { Independence } \\
\text { Day*Weekend }\end{array}$ & 0.38 & 7.31 & 1.43 & 12.84 & 0.58 & 9.80 & 0.23 & 3.13 & - & - \\
\hline Labor Day & -0.41 & -10.00 & -0.42 & -5.00 & -0.59 & -5.93 & -0.44 & -4.64 & -0.47 & -3.00 \\
\hline Columbus Day & -0.16 & -4.36 & -0.32 & -4.48 & -0.04 & -0.98 & 0.02 & 0.23 & -0.1 & -4.24 \\
\hline Veterans Day & -0.12 & -1.99 & -0.1 & -1.17 & -0.16 & -0.59 & 0.59 & 1.82 & -0.07 & -1.99 \\
\hline
\end{tabular}


Table C.6 (Continued)

\begin{tabular}{|c|c|c|c|c|c|c|c|c|c|c|}
\hline Veterans Day Observed & -0.03 & -0.92 & -0.05 & -0.5 & 0.12 & 4.56 & -0.4 & -1.67 & -0.27 & -2.72 \\
\hline Veterans Day*Weekend & 0.14 & 1.93 & 0.04 & 0.38 & -0.04 & -0.14 & -2.05 & -9.97 & -0.05 & -0.24 \\
\hline Good Friday & -0.09 & -2.22 & -0.02 & -0.20 & -0.16 & -1.70 & -0.08 & -1.02 & -0.03 & -0.25 \\
\hline CicLAvia: Heart of LA & - & - & - & - & - & - & - & - & 1.09 & 8.48 \\
\hline Aquatennial Fireworks & - & - & - & - & - & - & 0.08 & 2.12 & - & - \\
\hline St. Patrick's Day Parade & 0.08 & 0.86 & -0.21 & -2.74 & 0.01 & 0.24 & - & - & - & - \\
\hline Lollapalooza & - & - & - & - & 0.07 & 1.52 & - & - & - & - \\
\hline Marathon & - & - & -0.23 & -1.26 & 0.15 & 3.07 & - & - & - & - \\
\hline Air and Water Show & - & - & - & - & 0.20 & 4.91 & - & - & - & - \\
\hline Pride Parade & 0.03 & 0.54 & 0.01 & 0.08 & 0.15 & 2.67 & 0.14 & 2.30 & 0.01 & 0.16 \\
\hline Jazz Festival Saturday & - & - & - & - & 0.12 & 2.46 & - & - & - & - \\
\hline Jazz Festival Sunday & - & - & - & - & 0.09 & 2.08 & - & - & - & - \\
\hline $\begin{array}{l}\text { Cherry Blossom Festival } \\
\text { Saturday }\end{array}$ & 0.09 & 2.04 & - & - & - & - & - & - & - & - \\
\hline $\begin{array}{l}\text { Cherry Blossom Festival } \\
\text { Weekday }\end{array}$ & 0.01 & 0.40 & - & - & - & - & - & - & - & - \\
\hline H-Street Festival & 0.12 & 4.52 & - & - & - & - & - & - & - & - \\
\hline Monday & -0.07 & -5.94 & -0.07 & -2.19 & -0.07 & -4.25 & -0.08 & -3.41 & -0.04 & -1.90 \\
\hline Tuesday & 0.00 & 0.15 & -0.02 & -0.59 & 0.00 & 0.00 & 0.00 & -0.07 & 0.00 & -0.13 \\
\hline Thursday & 0.00 & 0.39 & 0.02 & 0.55 & -0.01 & -0.52 & -0.01 & -0.51 & 0.02 & 0.83 \\
\hline
\end{tabular}


Table C.6 (Continued)

\begin{tabular}{|c|c|c|c|c|c|c|c|c|c|c|}
\hline Friday & -0.02 & -1.52 & -0.05 & -1.72 & -0.06 & -3.44 & -0.04 & -1.66 & -0.03 & -1.32 \\
\hline Saturday & -0.35 & -24.54 & -0.53 & -17.3 & -0.60 & -30.68 & -0.40 & -16.89 & -0.43 & -16.95 \\
\hline Sunday & -0.47 & -33.98 & -0.63 & -21.00 & -0.74 & -34.95 & -0.46 & -20.63 & -0.50 & -16.78 \\
\hline Number of Observation & \multicolumn{2}{|c|}{2849.00} & \multicolumn{2}{|c|}{1704.00} & \multicolumn{2}{|c|}{1760.00} & \multicolumn{2}{|c|}{1727.00} & \multicolumn{2}{|c|}{975.00} \\
\hline R-Squared & \multicolumn{2}{|c|}{0.87} & \multicolumn{2}{|c|}{0.88} & \multicolumn{2}{|c|}{0.93} & \multicolumn{2}{|c|}{0.86} & \multicolumn{2}{|c|}{0.70} \\
\hline Adjusted R-Squared & \multicolumn{2}{|c|}{0.86} & \multicolumn{2}{|c|}{0.87} & \multicolumn{2}{|c|}{0.92} & \multicolumn{2}{|c|}{0.86} & \multicolumn{2}{|c|}{0.68} \\
\hline Durbin Watson's Test & \multicolumn{2}{|c|}{1.51} & \multicolumn{2}{|c|}{0.77} & \multicolumn{2}{|c|}{1.45} & \multicolumn{2}{|c|}{1.09} & \multicolumn{2}{|c|}{0.67} \\
\hline MAPE & \multicolumn{2}{|c|}{0.13} & \multicolumn{2}{|c|}{0.26} & \multicolumn{2}{|c|}{0.16} & \multicolumn{2}{|c|}{0.20} & \multicolumn{2}{|c|}{0.16} \\
\hline
\end{tabular}


Appendix D: Hypotheses Models - Non-Members

Table D.1: Federal Holidays Grouped Plus Weekend Variable

\begin{tabular}{|c|c|c|c|c|c|c|c|c|c|c|}
\hline & \multicolumn{2}{|c|}{$\begin{array}{l}\text { Bluebike } \\
\text { Boston }\end{array}$} & \multicolumn{2}{|c|}{$\begin{array}{l}\text { Metro Los } \\
\text { Angeles }\end{array}$} & \multicolumn{2}{|c|}{$\begin{array}{c}\text { Nice Ride } \\
\text { Minneapolis }\end{array}$} & \multicolumn{2}{|c|}{$\begin{array}{c}\text { Divvy } \\
\text { Chicago }\end{array}$} & \multicolumn{2}{|c|}{$\begin{array}{l}\text { Capital Bikeshare } \\
\text { Washington D.C. }\end{array}$} \\
\hline & Beta & t-stat & Beta & t-stat & Beta & t-stat & Beta & t-stat & Beta & t-stat \\
\hline Constant & 0.63 & 1.22 & -3.68 & -0.52 & 2.61 & 4.22 & 3.19 & 11.87 & 1.82 & 4.07 \\
\hline Average wind speed (NOAA Data) & -0.03 & -7.03 & 0.00 & 0.45 & -0.02 & -5.75 & -0.01 & -7.80 & -0.01 & -6.48 \\
\hline Snowfall (NOAA Data) & -0.16 & -3.16 & - & - & -0.22 & -10.76 & -0.12 & -4.66 & -0.15 & -2.44 \\
\hline Snow Depth (NOAA Data) & - & - & - & - & -0.24 & -10.91 & -0.08 & -7.64 & -0.16 & -3.53 \\
\hline Maximum temperature (NOAA data) & 0.11 & 4.58 & 0.39 & 1.42 & -0.02 & -0.74 & 0.05 & 4.30 & 0.05 & 2.47 \\
\hline $\begin{array}{l}\text { Moving average of maximum } \\
\text { temperature with 3-days span }\end{array}$ & 0.01 & 4.50 & 0.00 & -0.65 & 0.01 & 2.39 & 0.01 & 5.43 & 0.01 & 4.98 \\
\hline $\begin{array}{l}\text { Moving average of maximum } \\
\text { temperature with } 30 \text {-days span }\end{array}$ & 0.02 & 5.96 & -0.03 & -5.35 & 0.01 & 3.01 & 0.00 & 1.17 & 0.01 & 5.47 \\
\hline Maximum dewpoint (WU data) & -0.01 & -4.27 & 0.00 & 0.26 & -0.02 & -10.30 & -0.02 & -9.63 & -0.02 & -8.83 \\
\hline 2013 indicator & - & - & - & - & 0.33 & 9.35 & - & - & 0.45 & 16.23 \\
\hline 2014 indicator & - & - & - & - & 0.80 & 18.92 & - & - & 0.51 & 17.18 \\
\hline 2015 indicator & - & - & - & - & 0.95 & 28.76 & - & - & 0.57 & 17.95 \\
\hline 2016 indicator & -0.36 & -6.90 & - & - & 0.39 & 11.14 & -0.08 & -2.21 & 0.73 & 23.97 \\
\hline 2017 indicator & -0.89 & -16.38 & - & - & 0.51 & 14.96 & -0.13 & -3.71 & 1.02 & 38.03 \\
\hline 2018 indicator & -0.19 & -3.92 & 0.49 & 17.94 & 1.32 & 32.88 & -0.05 & -1.54 & 0.84 & 28.78 \\
\hline 2019 indicator & 0.44 & 9.04 & 0.08 & 2.72 & 0.77 & 20.63 & 0.32 & 9.02 & 0.29 & 9.88 \\
\hline Monday & 0.01 & 0.19 & 0.00 & 0.06 & -0.01 & -0.43 & 0.16 & 4.44 & 0.16 & 5.11 \\
\hline
\end{tabular}


Table D.1 (Continued)

\begin{tabular}{|c|c|c|c|c|c|c|c|c|c|c|}
\hline Tuesday & -0.01 & -0.19 & 0.08 & 2.08 & 0.01 & 0.33 & 0.03 & 0.73 & 0.04 & 1.49 \\
\hline Thursday & 0.06 & 1.22 & 0.09 & 2.24 & 0.05 & 1.46 & 0.12 & 3.49 & 0.09 & 3.33 \\
\hline Friday & 0.19 & 3.89 & 0.27 & 7.21 & 0.36 & 10.08 & 0.46 & 13.05 & 0.38 & 13.52 \\
\hline Weekend Indicator & 0.32 & 6.76 & 0.55 & 16.39 & 0.82 & 28.70 & 0.88 & 26.10 & 0.86 & 33.07 \\
\hline January indicator & -0.53 & -3.02 & -0.41 & -4.99 & - & - & -1.23 & -9.85 & -0.26 & -2.74 \\
\hline February indicator & -0.48 & -2.71 & -0.45 & -5.40 & - & - & -1.11 & -8.87 & -0.29 & -3.26 \\
\hline March indicator & -0.04 & -0.21 & -0.43 & -5.14 & - & - & -0.67 & -6.24 & 0.13 & 1.58 \\
\hline April indicator & 0.51 & 3.70 & -0.39 & -6.27 & -0.47 & -5.40 & -0.71 & -8.08 & 0.20 & 3.13 \\
\hline May indicator & 0.33 & 3.46 & -0.53 & -9.48 & -0.19 & -3.50 & -0.31 & -5.06 & 0.08 & 1.73 \\
\hline June indicator & 0.19 & 2.99 & -0.37 & -6.76 & -0.04 & -1.29 & -0.16 & -4.04 & -0.02 & -0.76 \\
\hline August indicator & -0.09 & -1.73 & 0.11 & 2.31 & -0.16 & -7.09 & -0.11 & -3.32 & -0.10 & -3.63 \\
\hline September indicator & -0.03 & -0.49 & 0.08 & 1.67 & -0.39 & -14.11 & -0.36 & -8.77 & -0.30 & -9.66 \\
\hline October indicator & 0.24 & 3.31 & -0.01 & -0.15 & -0.36 & -7.17 & -0.37 & -7.28 & -0.15 & -3.67 \\
\hline November indicator & 0.29 & 2.65 & -0.24 & -4.24 & -0.66 & -6.15 & -0.64 & -7.73 & -0.17 & -2.80 \\
\hline December indicator & -0.01 & -0.09 & -0.43 & -5.63 & - & - & -0.95 & -9.22 & -0.22 & -2.61 \\
\hline Federal holidays indicator & 0.04 & 0.29 & 0.48 & 5.21 & 0.64 & 7.53 & 0.56 & 6.92 & 0.66 & 12.11 \\
\hline Cherry Blossom Festival Saturday & - & - & - & - & - & - & - & - & 0.39 & 4.66 \\
\hline Cherry Blossom Festival Weekday & - & - & - & - & - & - & - & - & 0.15 & 3.80 \\
\hline $\begin{array}{l}\text { Quadratic effects of maximum } \\
\text { temperature (NOAA Data) }\end{array}$ & 0.00 & -1.14 & 0.00 & -1.27 & 0.00 & 4.72 & 0.00 & 4.31 & 0.00 & 2.08 \\
\hline $\begin{array}{l}\text { Cubic effects of maximum } \\
\text { temperature (NOAA Data) }\end{array}$ & 0.00 & -0.82 & 0.00 & 1.13 & 0.00 & -7.00 & 0.00 & -7.04 & 0.00 & -4.58 \\
\hline $\mathrm{I}(\mathrm{PRCP}>0$ \& SNOW $==0)$ & -0.13 & -3.30 & -0.06 & -0.84 & -0.11 & -4.40 & -0.21 & -5.96 & -0.09 & -3.62 \\
\hline $\mathrm{I}(\mathrm{PRCP}>0 \& \mathrm{SNOW}==0) * \mathrm{PRCP}$ & -0.94 & -5.77 & -2.02 & -4.29 & -0.49 & -7.14 & -0.53 & -5.33 & -0.89 & -8.80 \\
\hline $\begin{array}{l}\mathrm{I}(\mathrm{PRCP}>0 \& \mathrm{SNOW}==0) * \\
\mathrm{PRCP}^{\wedge} 2\end{array}$ & 0.23 & 2.32 & 1.01 & 3.18 & 0.10 & 3.58 & 0.02 & 0.58 & 0.16 & 3.32 \\
\hline
\end{tabular}


Table D.1 (Continued)

\begin{tabular}{|c|c|c|c|c|c|c|c|c|c|}
\hline $\mathrm{I}(\mathrm{SNOW}>0)$ & -0.35 & -2.62 & - & - & -0.08 & -0.57 & \begin{tabular}{|l|l|}
-0.13 & -1.99 \\
\end{tabular} & -0.30 & -2.56 \\
\hline Number of Observation & \multicolumn{2}{|c|}{1700.00} & \multicolumn{2}{|c|}{975.00} & \multicolumn{2}{|c|}{1727.00} & 1791.00 & \multicolumn{2}{|c|}{2875.00} \\
\hline R-Squared & \multicolumn{2}{|c|}{0.85} & \multicolumn{2}{|c|}{0.60} & \multicolumn{2}{|c|}{0.88} & 0.94 & \multicolumn{2}{|c|}{0.87} \\
\hline Adjusted R-Squared & \multicolumn{2}{|c|}{0.85} & \multicolumn{2}{|c|}{0.59} & \multicolumn{2}{|c|}{0.88} & 0.94 & \multicolumn{2}{|c|}{0.87} \\
\hline Durbin Watson's Test & \multicolumn{2}{|c|}{1.01} & \multicolumn{2}{|c|}{0.87} & \multicolumn{2}{|c|}{1.30} & 1.50 & \multicolumn{2}{|c|}{1.31} \\
\hline MAPE & \multicolumn{2}{|c|}{0.54} & \multicolumn{2}{|c|}{0.27} & \multicolumn{2}{|c|}{0.32} & 0.39 & \multicolumn{2}{|c|}{0.33} \\
\hline AIC & \multicolumn{2}{|c|}{2986.90} & \multicolumn{2}{|c|}{656.00} & \multicolumn{2}{|c|}{1518.00} & 2311.51 & \multicolumn{2}{|c|}{2981.49} \\
\hline
\end{tabular}

Table D.2: Federal Holidays Grouped and Saturday and Sunday Separately

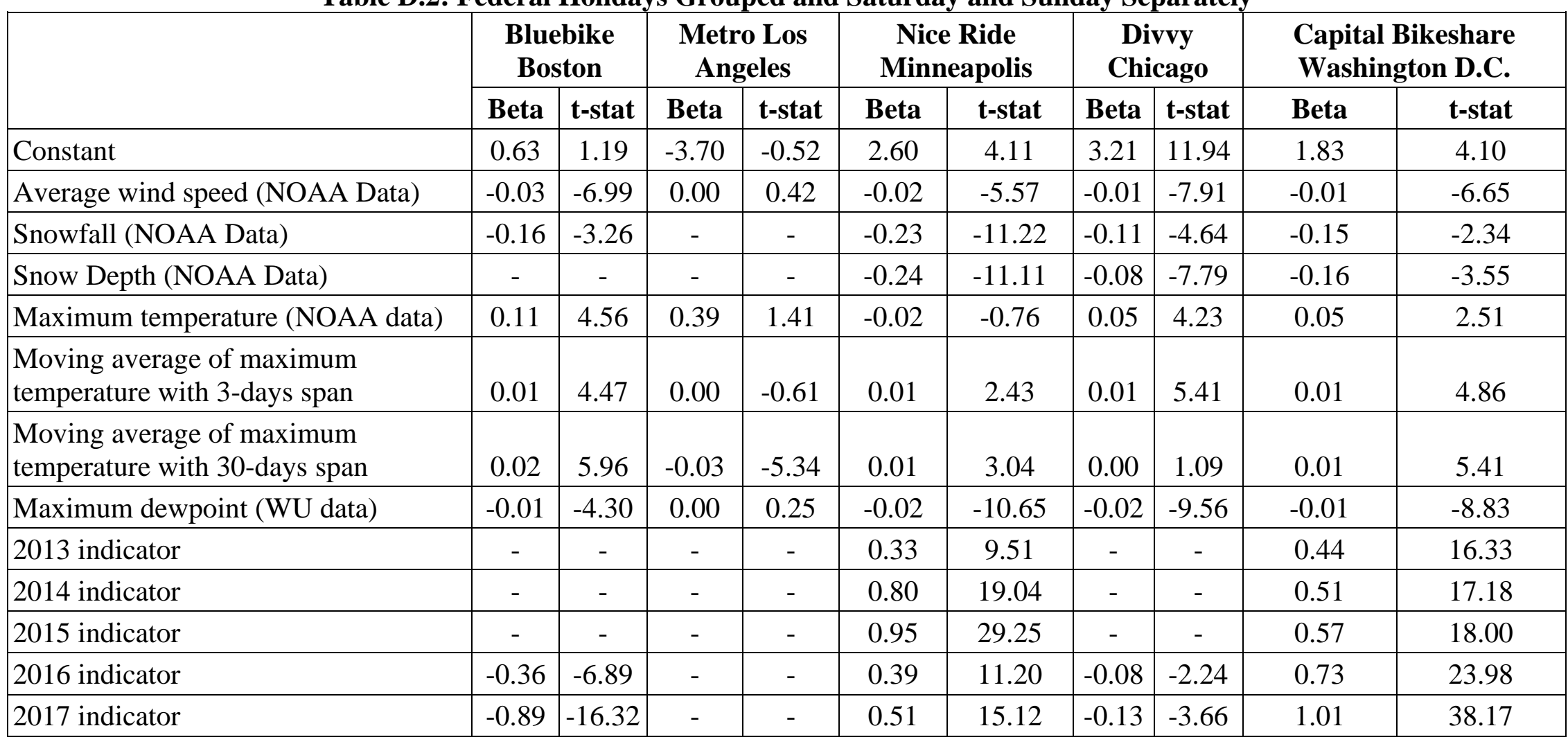


Table D.2 (Continued)

\begin{tabular}{|c|c|c|c|c|c|c|c|c|c|c|}
\hline 2018 indicator & -0.19 & -3.89 & 0.49 & 18.01 & 1.32 & 33.12 & -0.05 & -1.51 & 0.84 & 28.98 \\
\hline 2019 indicator & 0.44 & 9.07 & 0.09 & 2.77 & 0.77 & 20.95 & 0.32 & 9.09 & 0.29 & 9.93 \\
\hline Monday & 0.02 & 0.29 & -0.01 & -0.15 & -0.02 & -0.44 & 0.16 & 4.59 & 0.16 & 5.31 \\
\hline Tuesday & -0.01 & -0.11 & 0.07 & 1.87 & 0.01 & 0.40 & 0.03 & 0.76 & 0.04 & 1.53 \\
\hline Thursday & 0.05 & 1.05 & 0.07 & 1.93 & 0.05 & 1.44 & 0.11 & 3.39 & 0.09 & 3.12 \\
\hline Friday & 0.17 & 3.44 & 0.26 & 7.06 & 0.35 & 10.12 & 0.45 & 13.17 & 0.38 & 13.65 \\
\hline Saturday & 0.39 & 6.81 & 0.56 & 14.04 & 0.92 & 28.95 & 0.98 & 25.84 & 0.94 & 32.36 \\
\hline Sunday & 0.25 & 4.62 & 0.54 & 13.39 & 0.71 & 22.01 & 0.79 & 18.43 & 0.79 & 26.64 \\
\hline January indicator & -0.53 & -3.00 & -0.41 & -4.97 & - & - & -1.23 & -9.86 & -0.26 & -2.83 \\
\hline February indicator & -0.48 & -2.69 & -0.45 & -5.39 & - & - & -1.11 & -8.92 & -0.30 & -3.38 \\
\hline March indicator & -0.04 & -0.21 & -0.43 & -5.12 & - & - & -0.67 & -6.26 & 0.13 & 1.59 \\
\hline April indicator & 0.51 & 3.70 & -0.39 & -6.27 & -0.47 & -5.37 & -0.71 & -8.13 & 0.21 & 3.25 \\
\hline May indicator & 0.33 & 3.48 & -0.53 & -9.46 & -0.18 & -3.43 & -0.31 & -5.08 & 0.07 & 1.67 \\
\hline June indicator & 0.19 & 2.98 & -0.37 & -6.76 & -0.04 & -1.25 & -0.16 & -4.13 & -0.03 & -0.82 \\
\hline August indicator & -0.09 & -1.74 & 0.11 & 2.32 & -0.16 & -7.19 & -0.11 & -3.40 & -0.10 & -3.74 \\
\hline September indicator & -0.03 & -0.47 & 0.08 & 1.69 & -0.39 & -14.20 & -0.35 & -8.90 & -0.30 & -9.94 \\
\hline October indicator & 0.24 & 3.32 & -0.01 & -0.12 & -0.36 & -7.05 & -0.37 & -7.27 & -0.16 & -3.80 \\
\hline November indicator & 0.29 & 2.64 & -0.24 & -4.33 & -0.65 & -6.17 & -0.63 & -7.73 & -0.18 & -2.90 \\
\hline December indicator & -0.01 & -0.08 & -0.42 & -5.61 & - & - & -0.94 & -9.23 & -0.22 & -2.71 \\
\hline \begin{tabular}{|l} 
Federal Holidays Indicator \\
\end{tabular} & 0.00 & -0.01 & 0.45 & 4.95 & 0.62 & 7.43 & 0.41 & 5.38 & 0.52 & 10.42 \\
\hline Cherry Blossom Festival Saturday & - & - & - & - & - & - & - & - & 0.30 & 3.56 \\
\hline Cherry Blossom Festival Weekday & - & - & - & - & - & - & - & - & 0.14 & 3.60 \\
\hline $\begin{array}{l}\text { Quadratic effects of maximum } \\
\text { temperature (NOAA Data) }\end{array}$ & 0.00 & -1.14 & 0.00 & -1.26 & 0.00 & 4.70 & 0.00 & 4.37 & 0.00 & 2.03 \\
\hline $\begin{array}{l}\text { Cubic effects of maximum } \\
\text { temperature (NOAA Data) }\end{array}$ & 0.00 & -0.81 & 0.00 & 1.12 & 0.00 & -6.97 & 0.00 & -7.08 & 0.00 & -4.53 \\
\hline
\end{tabular}


Table D.2 (Continued)

\begin{tabular}{|c|c|c|c|c|c|c|c|c|c|c|}
\hline $\mathrm{I}(\mathrm{PRCP}>0$ \& SNOW $==0)$ & -0.13 & -3.32 & -0.06 & -0.78 & -0.11 & -4.42 & -0.21 & -5.90 & -0.10 & -3.80 \\
\hline $\mathrm{I}(\mathrm{PRCP}>0$ \& SNOW $==0) * \mathrm{PRCP}$ & -0.94 & -5.76 & -2.04 & -4.36 & -0.48 & -7.04 & -0.53 & -5.27 & -0.88 & -8.69 \\
\hline $\begin{array}{l}\mathrm{I}(\mathrm{PRCP}>0 \& \mathrm{SNOW}==0) * \\
\mathrm{PRCP}^{\wedge} 2\end{array}$ & 0.23 & 2.33 & 1.03 & 3.24 & 0.10 & 3.58 & 0.02 & 0.47 & 0.16 & 3.18 \\
\hline $\mathrm{I}(\mathrm{SNOW}>0)$ & -0.34 & -2.56 & - & - & -0.07 & -0.49 & -0.13 & -1.95 & -0.30 & -2.59 \\
\hline Number of Observation & \multicolumn{2}{|c|}{1700.00} & \multicolumn{2}{|c|}{975.00} & \multicolumn{2}{|c|}{1727.00} & \multicolumn{2}{|c|}{1790.00} & \multicolumn{2}{|c|}{2874.00} \\
\hline R-Squared & \multicolumn{2}{|c|}{0.85} & \multicolumn{2}{|c|}{0.60} & \multicolumn{2}{|c|}{0.89} & \multicolumn{2}{|c|}{0.94} & \multicolumn{2}{|c|}{0.88} \\
\hline Adjusted R-Squared & \multicolumn{2}{|c|}{0.85} & \multicolumn{2}{|c|}{0.59} & \multicolumn{2}{|c|}{0.88} & \multicolumn{2}{|c|}{0.94} & \multicolumn{2}{|c|}{0.87} \\
\hline Durbin Watson's Test & \multicolumn{2}{|c|}{1.00} & \multicolumn{2}{|c|}{0.88} & \multicolumn{2}{|c|}{1.26} & \multicolumn{2}{|c|}{1.47} & \multicolumn{2}{|c|}{1.29} \\
\hline MAPE & \multicolumn{2}{|c|}{0.54} & \multicolumn{2}{|c|}{0.27} & \multicolumn{2}{|c|}{0.31} & \multicolumn{2}{|c|}{0.38} & \multicolumn{2}{|c|}{0.33} \\
\hline AIC & \multicolumn{2}{|c|}{2986.27} & \multicolumn{2}{|c|}{647.00} & \multicolumn{2}{|c|}{1477.00} & \multicolumn{2}{|c|}{2286.84} & \multicolumn{2}{|c|}{2947.61} \\
\hline
\end{tabular}

Table D.3: Non-Work Holidays Grouped by Business Closure Rate

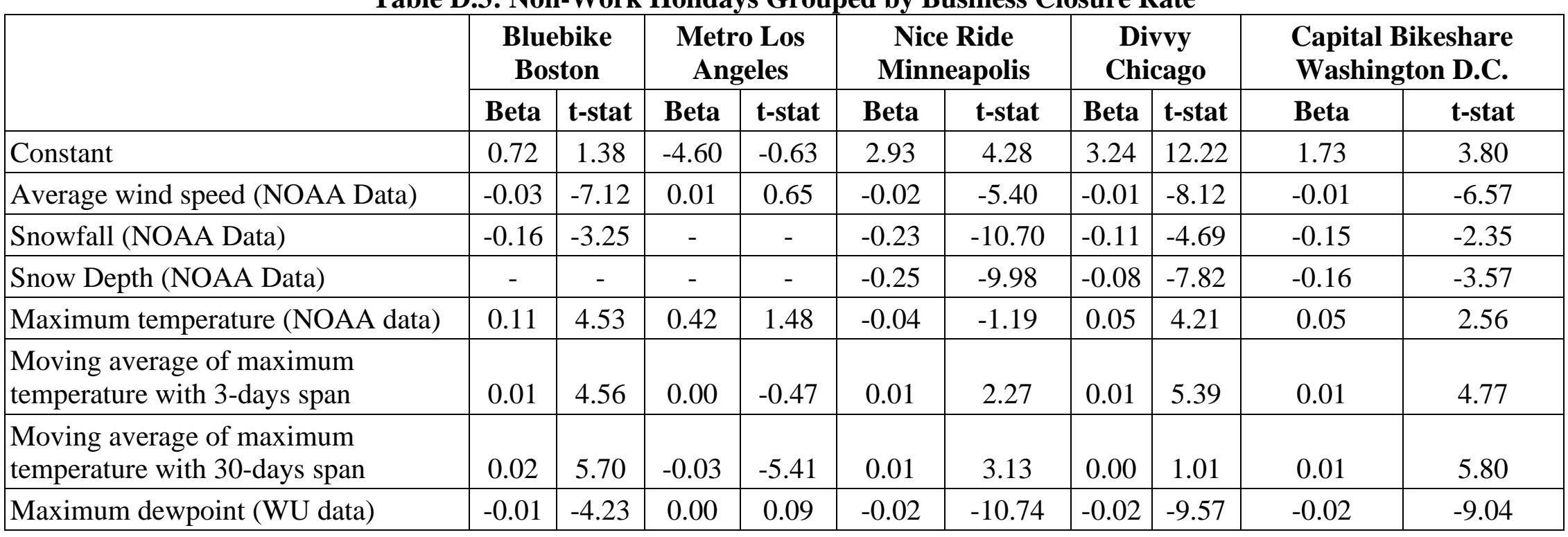


Table D.3 (Continued)

\begin{tabular}{|c|c|c|c|c|c|c|c|c|c|c|}
\hline 2013 indicator & - & - & - & - & 0.33 & 9.66 & - & - & 0.45 & 16.64 \\
\hline 2014 indicator & - & - & - & - & 0.80 & 19.09 & - & - & 0.51 & 17.35 \\
\hline 2015 indicator & - & - & - & - & 0.94 & 29.73 & - & - & 0.57 & 18.11 \\
\hline 2016 indicator & -0.36 & -7.03 & - & - & 0.39 & 11.34 & -0.07 & -2.09 & 0.73 & 24.12 \\
\hline 2017 indicator & -0.90 & -16.66 & - & - & 0.51 & 15.29 & -0.13 & -3.61 & 1.02 & 38.33 \\
\hline 2018 indicator & -0.20 & -4.09 & 0.49 & 18.16 & 1.32 & 33.25 & -0.05 & -1.51 & 0.84 & 29.26 \\
\hline 2019 indicator & 0.43 & 9.09 & 0.09 & 2.89 & 0.77 & 20.94 & 0.32 & 9.09 & 0.29 & 10.08 \\
\hline Monday & 0.02 & 0.31 & 0.00 & -0.11 & -0.01 & -0.23 & 0.16 & 4.64 & 0.16 & 5.39 \\
\hline Tuesday & 0.00 & -0.06 & 0.06 & 1.76 & 0.01 & 0.37 & 0.02 & 0.62 & 0.04 & 1.43 \\
\hline Thursday & 0.06 & 1.13 & 0.07 & 1.86 & 0.05 & 1.40 & 0.11 & 3.21 & 0.09 & 3.09 \\
\hline Friday & 0.17 & 3.49 & 0.26 & 6.86 & 0.35 & 9.89 & 0.45 & 12.98 & 0.36 & 13.15 \\
\hline \begin{tabular}{|l|} 
Saturday \\
\end{tabular} & 0.39 & 6.90 & 0.56 & 13.98 & 0.92 & 28.73 & 0.98 & 25.60 & 0.94 & 32.10 \\
\hline Sunday & 0.25 & 4.55 & 0.53 & 13.27 & 0.71 & 22.06 & 0.79 & 18.61 & 0.78 & 26.24 \\
\hline January indicator & -0.59 & -3.39 & -0.41 & -4.90 & - & - & -1.25 & -10.06 & -0.23 & -2.44 \\
\hline February indicator & -0.54 & -3.07 & -0.44 & -5.31 & - & - & -1.12 & -9.08 & -0.26 & -2.96 \\
\hline March indicator & -0.09 & -0.52 & -0.43 & -5.21 & - & - & -0.69 & -6.48 & 0.15 & 1.91 \\
\hline April indicator & 0.46 & 3.40 & -0.41 & -6.47 & -0.47 & -5.32 & -0.73 & -8.34 & 0.22 & 3.48 \\
\hline May indicator & 0.30 & 3.21 & -0.55 & -9.71 & -0.19 & -3.42 & -0.33 & -5.39 & 0.09 & 1.96 \\
\hline June indicator & 0.16 & 2.63 & -0.38 & -6.93 & -0.04 & -1.24 & -0.17 & -4.25 & -0.02 & -0.59 \\
\hline August indicator & -0.10 & -2.03 & 0.10 & 2.13 & -0.16 & -7.12 & -0.12 & -3.48 & -0.10 & -3.66 \\
\hline September indicator & -0.04 & -0.69 & 0.07 & 1.39 & -0.39 & -14.11 & -0.37 & -9.02 & -0.30 & -9.79 \\
\hline October indicator & 0.21 & 2.95 & -0.01 & -0.12 & -0.34 & -6.74 & -0.37 & -7.14 & -0.14 & -3.45 \\
\hline November indicator & 0.26 & 2.36 & -0.25 & -4.54 & -0.65 & -6.12 & -0.65 & -7.89 & -0.17 & -2.82 \\
\hline December indicator & -0.05 & -0.34 & -0.45 & -5.79 & - & - & -0.96 & -9.33 & -0.22 & -2.72 \\
\hline
\end{tabular}


Table D.3 (Continued)

\begin{tabular}{|c|c|c|c|c|c|c|c|c|c|c|}
\hline $\begin{array}{l}\text { Non-work Holidays Indicator } \\
\text { (including observed and actual } \\
\text { weekday holiday) }\end{array}$ & -0.19 & -0.92 & 0.62 & 4.96 & 0.77 & 7.25 & 0.56 & 6.02 & 0.54 & 9.09 \\
\hline $\begin{array}{l}\text { Mostly-work Holidays Indicator } \\
\text { (including observed and actual } \\
\text { weekday holiday) }\end{array}$ & -0.22 & -1.21 & 0.18 & 1.18 & 0.62 & 3.21 & 0.18 & 0.76 & 0.48 & 3.94 \\
\hline $\begin{array}{l}\text { Barely-work Holidays Indicator } \\
\text { (including observed and actual } \\
\text { weekday holiday) }\end{array}$ & 0.16 & 1.56 & 0.22 & 2.23 & 0.20 & 1.79 & 0.16 & 1.56 & 0.40 & 5.61 \\
\hline New Year*Weekend & 0.96 & 10.89 & - & - & - & - & 0.23 & 3.37 & 0.01 & 0.21 \\
\hline Christmas*Weekend & -0.55 & -7.27 & - & - & - & - & -2.09 & -30.36 & 0.37 & 8.36 \\
\hline Independence*Weekend & -1.51 & -19.50 & - & - & 0.06 & 1.74 & 0.31 & 6.33 & 0.86 & 15.01 \\
\hline Veterans*Weekend & 0.31 & 3.76 & 0.21 & 2.94 & -0.65 & -5.36 & -0.09 & -0.31 & 0.17 & 1.65 \\
\hline Cherry Blossom Festival Saturday & - & - & - & - & - & - & - & - & 0.31 & 3.61 \\
\hline Cherry Blossom Festival Weekday & - & - & - & - & - & - & - & - & 0.13 & 3.29 \\
\hline $\begin{array}{l}\text { Quadratic effects of maximum } \\
\text { temperature (NOAA Data) }\end{array}$ & 0.00 & -1.14 & 0.00 & -1.32 & 0.00 & 4.85 & 0.00 & 4.40 & 0.00 & 1.94 \\
\hline $\begin{array}{l}\text { Cubic effects of maximum } \\
\text { temperature (NOAA Data) }\end{array}$ & 0.00 & -0.80 & 0.00 & 1.18 & 0.00 & -6.97 & 0.00 & -7.12 & 0.00 & -4.42 \\
\hline $\mathrm{I}(\mathrm{PRCP}>0$ \& SNOW ==0) & -0.14 & -3.50 & -0.06 & -0.80 & -0.12 & -4.53 & -0.20 & -5.78 & -0.09 & -3.60 \\
\hline $\mathrm{I}(\mathrm{PRCP}>0$ \& SNOW $==0) * \mathrm{PRCP}$ & -0.93 & -5.72 & -2.07 & -4.41 & -0.48 & -6.98 & -0.53 & -5.35 & -0.90 & -8.73 \\
\hline $\begin{array}{l}\mathrm{I}(\mathrm{PRCP}>0 \& \mathrm{SNOW}==0) * \\
\mathrm{PRCP}^{\wedge} 2\end{array}$ & 0.23 & 2.32 & 1.04 & 3.28 & 0.10 & 3.57 & 0.02 & 0.51 & 0.16 & 3.24 \\
\hline I(SNOW > 0) & -0.35 & -2.63 & - & - & -0.11 & -0.73 & -0.12 & -1.86 & -0.29 & -2.50 \\
\hline Number of Observation & \multicolumn{2}{|c|}{1700.00} & \multicolumn{2}{|c|}{975.00} & \multicolumn{2}{|c|}{1727.00} & \multicolumn{2}{|c|}{1784.00} & \multicolumn{2}{|c|}{2869.00} \\
\hline R-Squared & \multicolumn{2}{|c|}{0.86} & \multicolumn{2}{|c|}{0.60} & \multicolumn{2}{|c|}{0.89} & \multicolumn{2}{|c|}{0.94} & \multicolumn{2}{|c|}{0.88} \\
\hline Adjusted R-Squared & \multicolumn{2}{|c|}{0.85} & \multicolumn{2}{|c|}{0.59} & \multicolumn{2}{|c|}{0.89} & \multicolumn{2}{|c|}{0.94} & \multicolumn{2}{|c|}{0.87} \\
\hline Durbin Watson's Test & \multicolumn{2}{|c|}{1.02} & \multicolumn{2}{|c|}{0.88} & \multicolumn{2}{|c|}{1.26} & \multicolumn{2}{|c|}{1.47} & \multicolumn{2}{|c|}{1.30} \\
\hline
\end{tabular}


Table D.3 (Continued)

\begin{tabular}{|l|c|c|c|c|c|}
\hline MAPE & 0.54 & 0.27 & 0.31 & 0.38 & 0.33 \\
\hline AIC & 2980.00 & 656.00 & 1478.00 & 2272.60 & 2937.34 \\
\hline
\end{tabular}

Table D.4: Holiday-Specific Effects with Additional Grouped by Saturday and Sunday Before Monday Federal Holidays

\begin{tabular}{|c|c|c|c|c|c|c|c|c|c|c|}
\hline & $\begin{array}{l}\text { Capi } \\
\text { Was }\end{array}$ & $\begin{array}{l}\text { share } \\
\text { D.C. }\end{array}$ & $\begin{array}{r}\text { Bluc } \\
\text { Bo }\end{array}$ & $\begin{array}{l}\text { bike } \\
\text { ton }\end{array}$ & $\begin{array}{r}\text { Di } \\
\text { Chi }\end{array}$ & $\begin{array}{l}\text { vvy } \\
\text { cago }\end{array}$ & $\begin{array}{l}\text { Nic } \\
\text { Min }\end{array}$ & $\begin{array}{l}\text { ide } \\
\text { polis }\end{array}$ & $\begin{array}{l}\text { Metr } \\
\text { Ang }\end{array}$ & $\begin{array}{l}\text { Los } \\
\text { les }\end{array}$ \\
\hline & Beta & t-stat & Beta & t-stat & Beta & t-stat & Beta & t-stat & Beta & t-stat \\
\hline Constant & 1.66 & 3.67 & 0.86 & 1.64 & 3.30 & 12.38 & 1.79 & 1.95 & -16.74 & -2.68 \\
\hline $\begin{array}{l}\text { Average wind speed (NOAA } \\
\text { Data) }\end{array}$ & -0.01 & -6.54 & -0.03 & -7.15 & -0.01 & -8.08 & -0.02 & -5.13 & -0.01 & -1.18 \\
\hline Snowfall (NOAA Data) & -0.14 & -2.26 & -0.16 & -3.16 & -0.11 & -4.72 & -0.28 & -4.47 & - & - \\
\hline Snow Depth (NOAA Data) & -0.16 & -3.55 & - & - & -0.07 & -7.71 & - & - & - & - \\
\hline $\begin{array}{l}\text { Maximum temperature } \\
\text { (NOAA data) }\end{array}$ & 0.06 & 2.84 & 0.10 & 4.48 & 0.05 & 4.28 & 0.01 & 0.18 & 0.87 & 3.62 \\
\hline $\begin{array}{l}\text { Moving average of maximum } \\
\text { temperature with } 3 \text {-days span }\end{array}$ & 0.01 & 4.77 & 0.01 & 4.73 & 0.01 & 5.20 & 0.01 & 3.26 & 0.00 & -0.75 \\
\hline $\begin{array}{l}\text { Moving average of maximum } \\
\text { temperature with } 30 \text {-days } \\
\text { span }\end{array}$ & 0.01 & 5.60 & 0.02 & 5.24 & 0.002 & 0.76 & 0.01 & 2.67 & -0.03 & -4.30 \\
\hline $\begin{array}{l}\text { Maximum dewpoint (WU } \\
\text { data) }\end{array}$ & -0.01 & -9.05 & -0.01 & -4.15 & -0.02 & -9.70 & -0.02 & -10.80 & -0.010 & -2.18 \\
\hline 2013 indicator & 0.44 & 16.68 & - & - & - & - & 0.32 & 9.36 & - & - \\
\hline 2014 indicator & 0.51 & 17.53 & - & - & - & - & 0.80 & 19.31 & - & - \\
\hline 2015 indicator & 0.57 & 18.25 & - & - & - & - & 0.95 & 29.41 & - & - \\
\hline 2016 indicator & 0.72 & 24.24 & -0.37 & -7.23 & -0.07 & -2.04 & 0.39 & 11.51 & - & - \\
\hline 2017 indicator & 1.02 & 39.33 & -0.91 & -17.14 & -0.13 & -3.67 & 0.51 & 15.49 & - & - \\
\hline 2018 indicator & 0.84 & 29.46 & -0.21 & -4.28 & -0.05 & -1.57 & 1.28 & 30.71 & 0.48 & 17.34 \\
\hline
\end{tabular}


Table D.4 (Continued)

\begin{tabular}{|c|c|c|c|c|c|c|c|c|c|c|}
\hline 2019 indicator & 0.29 & 10.15 & 0.43 & 9.02 & 0.32 & 9.14 & 0.78 & 20.87 & 0.06 & 2.06 \\
\hline Monday & 0.16 & 5.21 & -0.01 & -0.13 & 0.15 & 4.16 & -0.01 & -0.35 & 0.00 & -0.10 \\
\hline Tuesday & 0.04 & 1.47 & 0.00 & -0.01 & 0.02 & 0.66 & 0.01 & 0.35 & 0.07 & 1.77 \\
\hline Thursday & 0.09 & 3.12 & 0.06 & 1.15 & 0.11 & 3.35 & 0.06 & 1.72 & 0.08 & 1.84 \\
\hline Friday & 0.36 & 13.01 & 0.18 & 3.63 & 0.44 & 13.19 & 0.37 & 10.26 & 0.28 & 6.746 \\
\hline Saturday & 0.92 & 31.59 & 0.39 & 6.74 & 0.96 & 24.34 & 0.91 & 26.34 & 0.55 & 12.48 \\
\hline Sunday & 0.74 & 24.90 & 0.24 & 4.32 & 0.76 & 17.77 & 0.67 & 19.48 & 0.53 & 11.70 \\
\hline January indicator & -0.25 & -2.65 & -0.65 & -3.74 & -1.30 & -10.18 & - & - & -0.58 & -5.96 \\
\hline February indicator & -0.31 & -3.46 & -0.60 & -3.45 & -1.18 & -9.42 & - & - & -0.46 & -5.23 \\
\hline March indicator & 0.15 & 1.82 & -0.14 & -0.82 & -0.73 & -6.78 & - & - & -0.47 & -4.70 \\
\hline April indicator & 0.22 & 3.51 & 0.42 & 3.12 & -0.76 & -8.59 & -0.52 & -5.66 & -0.39 & -5.88 \\
\hline May indicator & 0.06 & 1.43 & 0.26 & 2.85 & -0.37 & -6.09 & -0.20 & -3.53 & -0.56 & -9.58 \\
\hline June indicator & -0.01 & -0.28 & 0.16 & 2.65 & -0.16 & -4.07 & -0.03 & -1.16 & -0.38 & -6.63 \\
\hline August indicator & -0.09 & -3.37 & -0.08 & -1.61 & -0.10 & -3.09 & -0.16 & -7.20 & 0.10 & 2.22 \\
\hline September indicator & -0.31 & -10.58 & -0.06 & -1.07 & -0.37 & -9.76 & -0.41 & -15.26 & 0.05 & 0.97 \\
\hline October indicator & -0.16 & -3.94 & 0.20 & 2.84 & -0.41 & -7.85 & -0.33 & -6.17 & -0.06 & -1.28 \\
\hline November indicator & -0.18 & -3.00 & 0.24 & 2.24 & -0.65 & -8.06 & -0.52 & -4.56 & -0.33 & -5.51 \\
\hline December indicator & -0.22 & -2.68 & -0.04 & -0.26 & -0.97 & -9.32 & - & - & -0.57 & -6.93 \\
\hline $\begin{array}{l}\text { New Year's Day (actual } \\
\text { days, including weekend) }\end{array}$ & 0.57 & 4.69 & -0.29 & -0.59 & 0.38 & 3.82 & - & - & 0.91 & 8.55 \\
\hline $\begin{array}{l}\text { New Year's Day Observed } \\
\text { (only observed days, Friday } \\
\text { or Monday) }\end{array}$ & -0.32 & -1.35 & 1.11 & 13.07 & 0.65 & 9.72 & - & - & - & - \\
\hline New Year's Day*Weekend & -0.53 & -4.40 & 1.28 & 2.58 & -0.12 & -1.14 & - & - & - & - \\
\hline New Year's Eve & 0.53 & 2.56 & 0.02 & 0.07 & 0.13 & 0.49 & - & - & 0.65 & 3.88 \\
\hline Thanksgiving Day & 0.39 & 3.22 & -0.38 & -1.24 & 0.20 & 1.45 & -1.97 & -12.23 & -0.24 & -0.48 \\
\hline
\end{tabular}


Table D.4 (Continued)

\begin{tabular}{|c|c|c|c|c|c|c|c|c|c|c|}
\hline Day After Thanksgiving & 0.71 & 7.70 & -0.36 & -1.73 & -0.01 & -0.03 & -2.13 & -13.45 & 0.11 & 0.48 \\
\hline Christmas Day & 0.55 & 3.93 & -1.41 & -2.37 & 0.21 & 0.84 & - & - & 0.66 & 3.78 \\
\hline Christmas Day Observed & 0.74 & 15.71 & -0.58 & -6.59 & 0.93 & 12.37 & - & - & - & - \\
\hline Christmas Day*Weekend & -0.16 & -1.16 & 0.80 & 1.35 & -2.32 & -9.21 & - & - & - & - \\
\hline Christmas Eve & -0.21 & -1.21 & -0.74 & -3.93 & -0.34 & -0.89 & - & - & 0.07 & 0.43 \\
\hline Christmas Day & 0.55 & 3.93 & -1.41 & -2.37 & 0.21 & 0.84 & - & - & 0.66 & 3.78 \\
\hline Christmas Day Observed & 0.74 & 15.71 & -0.58 & -6.59 & 0.93 & 12.37 & - & - & - & - \\
\hline Christmas Day*Weekend & -0.16 & -1.16 & 0.80 & 1.35 & -2.32 & -9.21 & - & - & - & - \\
\hline Christmas Eve & -0.21 & -1.21 & -0.74 & -3.93 & -0.34 & -0.89 & - & - & 0.07 & 0.43 \\
\hline Martin Luther King's Day & 0.26 & 2.41 & 0.10 & 0.24 & 0.05 & 0.21 & - & - & 0.67 & 4.42 \\
\hline Memorial Day & 0.75 & 14.39 & 0.16 & 0.70 & 1.14 & 10.01 & 0.69 & 4.99 & 0.79 & 10.77 \\
\hline President Day & 0.63 & 2.18 & 0.33 & 1.65 & 0.04 & 0.15 & - & - & 0.40 & 1.05 \\
\hline Independence Day & 0.94 & 13.73 & 0.72 & 7.70 & 0.85 & 5.53 & 0.87 & 9.70 & 0.55 & 2.82 \\
\hline Independence Day Observed & 0.91 & 21.35 & -0.97 & -14.53 & 0.87 & 18.83 & 0.23 & 6.23 & - & - \\
\hline Independence Day*Weekend & -0.06 & -0.73 & -2.24 & -20.10 & -0.52 & -3.29 & -0.79 & -8.26 & - & - \\
\hline Labor Day & 0.67 & 6.30 & 0.56 & 1.85 & 0.71 & 4.21 & 1.00 & 13.74 & 0.60 & 3.31 \\
\hline Columbus Day & 0.38 & 4.11 & 0.01 & 0.06 & 0.57 & 7.86 & 0.07 & 0.485 & -0.03 & -0.29 \\
\hline Veterans Day & 0.26 & 2.75 & 0.25 & 0.80 & -0.17 & -0.74 & 1.01 & 3.07 & 0.01 & 0.09 \\
\hline Veterans Day Observed & 0.62 & 11.07 & 0.13 & 1.32 & 0.43 & 7.76 & 0.80 & 3.31 & 0.48 & 7.99 \\
\hline Veterans Day*Weekend & 0.06 & 0.51 & 0.07 & 0.23 & 0.15 & 0.45 & -1.76 & -8.18 & 0.21 & 2.38 \\
\hline Good Friday & 0.26 & 3.08 & 0.348 & 1.48 & 0.36 & 1.39 & 0.22 & 1.78 & 0.12 & 0.87 \\
\hline $\begin{array}{l}\text { Saturday Before Monday } \\
\text { Holidays }\end{array}$ & 0.15 & 2.16 & 0.03 & 0.16 & 0.19 & 2.57 & 0.14 & 2.05 & 0.12 & 0.99 \\
\hline $\begin{array}{l}\text { Sunday Before Monday } \\
\text { Holidays }\end{array}$ & 0.44 & 7.20 & 0.13 & 0.78 & 0.31 & 2.40 & 0.37 & 4.08 & 0.18 & 1.80 \\
\hline
\end{tabular}


Table D.4 (Continued)

\begin{tabular}{|c|c|c|c|c|c|c|c|c|c|c|}
\hline $\begin{array}{l}\text { Cherry Blossom Festival } \\
\text { Saturday }\end{array}$ & 0.31 & 3.59 & 0.00 & -1.07 & - & - & - & - & - & - \\
\hline $\begin{array}{l}\text { Cherry Blossom Festival } \\
\text { Weekday }\end{array}$ & 0.12 & 3.07 & 0.00 & -0.93 & - & - & - & - & - & - \\
\hline $\begin{array}{l}\text { Quadratic effects of } \\
\text { maximum temperature } \\
\text { (NOAA Data) }\end{array}$ & 0.001 & 1.71 & - & - & 0.00 & 4.42 & 0.00 & 2.6197 & -0.01 & -3.34 \\
\hline $\begin{array}{l}\text { Cubic effects of maximum } \\
\text { temperature (NOAA Data) }\end{array}$ & 0.00 & -4.25 & - & - & 0.00 & -7.26 & 0.00 & -4.37 & - & 3.06 \\
\hline $\mathrm{I}(\mathrm{PRCP}>0$ \& SNOW $==0)$ & -0.10 & -4.15 & -0.14 & -3.53 & -0.20 & -5.73 & -0.11 & -4.26 & - & - \\
\hline $\begin{array}{l}\text { I(PRCP > } 0 \text { \& SNOW ==0) } \\
* \text { PRCP }\end{array}$ & -0.87 & -8.66 & -0.95 & -5.88 & -0.53 & -5.37 & -0.48 & -6.93 & - & - \\
\hline $\begin{array}{l}\mathrm{I}(\mathrm{PRCP}>0 \text { \& } \mathrm{SNOW}==0) \\
* \mathrm{PRCP}^{\wedge} 2\end{array}$ & 0.16 & 3.17 & 0.23 & 2.37 & 0.02 & 0.52 & 0.10 & 3.50 & - & - \\
\hline $\mathrm{I}(\mathrm{SNOW}>0)$ & -0.30 & -2.59 & -0.35 & -2.68 & $\begin{array}{c}- \\
0.127 \\
\end{array}$ & -1.93 & -0.23 & -1.356 & - & - \\
\hline Number of Observation & \multicolumn{2}{|c|}{$2,852.00$} & \multicolumn{2}{|c|}{$1,642.00$} & \multicolumn{2}{|c|}{$1,767.00$} & \multicolumn{2}{|c|}{$1,680.00$} & \multicolumn{2}{|c|}{930.00} \\
\hline R-Squared & \multicolumn{2}{|c|}{0.88} & \multicolumn{2}{|c|}{0.86} & \multicolumn{2}{|c|}{0.94} & \multicolumn{2}{|c|}{0.88} & \multicolumn{2}{|c|}{0.56} \\
\hline \begin{tabular}{|l} 
Adjusted R-Squared \\
\end{tabular} & \multicolumn{2}{|c|}{0.88} & \multicolumn{2}{|c|}{0.85} & \multicolumn{2}{|c|}{0.94} & \multicolumn{2}{|c|}{0.88} & \multicolumn{2}{|c|}{0.53} \\
\hline Durbin Watson's Test & \multicolumn{2}{|c|}{1.33} & \multicolumn{2}{|c|}{1.03} & \multicolumn{2}{|c|}{1.51} & \multicolumn{2}{|c|}{1.23} & \multicolumn{2}{|c|}{0.88} \\
\hline MAPE & \multicolumn{2}{|c|}{0.32} & \multicolumn{2}{|c|}{0.53} & \multicolumn{2}{|c|}{0.37} & \multicolumn{2}{|c|}{0.31} & \multicolumn{2}{|c|}{0.29} \\
\hline AIC & \multicolumn{2}{|c|}{$2,858.96$} & \multicolumn{2}{|c|}{$2,961.58$} & \multicolumn{2}{|c|}{$2,250.44$} & \multicolumn{2}{|c|}{$1,579.12$} & \multicolumn{2}{|c|}{791.20} \\
\hline
\end{tabular}


Table D.5: Holiday-Specific Effects with Additional Individual Saturday and Sunday Before Monday Federal Holidays

\begin{tabular}{|c|c|c|c|c|c|c|c|c|c|c|}
\hline & \multicolumn{2}{|c|}{$\begin{array}{l}\text { Capital Bikeshare } \\
\text { Washington D.C. }\end{array}$} & \multicolumn{2}{|c|}{$\begin{array}{c}\text { Bluebike } \\
\text { Boston }\end{array}$} & \multicolumn{2}{|c|}{$\begin{array}{c}\text { Divvy } \\
\text { Chicago }\end{array}$} & \multicolumn{2}{|c|}{$\begin{array}{c}\text { Nice Ride } \\
\text { Minneapolis }\end{array}$} & \multicolumn{2}{|c|}{$\begin{array}{l}\text { Metro Los } \\
\text { Angeles }\end{array}$} \\
\hline & Beta & t-stat & Beta & t-stat & Beta & t-stat & Beta & t-stat & Beta & t-stat \\
\hline Constant & 1.57 & 3.42 & 0.78 & 1.47 & 3.36 & 12.54 & 1.74 & 1.89 & -16.77 & -2.66 \\
\hline Average wind speed (NOAA Data) & -0.01 & -6.59 & -0.03 & -7.12 & -0.01 & -8.07 & -0.02 & -5.14 & -0.01 & -1.42 \\
\hline Snowfall (NOAA Data) & -0.14 & -2.19 & -0.16 & -3.21 & -0.11 & -4.49 & -0.28 & -4.46 & - & - \\
\hline Snow Depth (NOAA Data) & -0.16 & -3.56 & - & - & -0.08 & -7.95 & - & - & - & - \\
\hline Maximum temperature (NOAA data) & 0.06 & 3.00 & 0.11 & 4.61 & 0.05 & 4.07 & 0.01 & 0.23 & 0.88 & 3.62 \\
\hline $\begin{array}{l}\text { Moving average of maximum } \\
\text { temperature with 3-days span }\end{array}$ & 0.01 & 4.74 & 0.01 & 4.69 & 0.01 & 5.41 & 0.01 & 3.14 & 0.00 & -0.70 \\
\hline $\begin{array}{l}\text { Moving average of maximum } \\
\text { temperature with } 30 \text {-days span }\end{array}$ & 0.01 & 5.63 & 0.02 & 5.29 & 0.001 & 0.56 & 0.01 & 2.75 & -0.03 & -4.32 \\
\hline Maximum dewpoint (WU data) & -0.01 & -8.99 & -0.01 & -4.08 & -0.03 & -9.74 & -0.02 & -10.87 & -0.01 & -2.14 \\
\hline 2013 indicator & 0.44 & 16.83 & - & - & - & - & 0.32 & 9.40 & - & - \\
\hline 2014 indicator & 0.51 & 17.64 & - & - & - & - & 0.80 & 19.31 & - & - \\
\hline 2015 indicator & 0.57 & 18.32 & - & - & - & - & 0.95 & 29.47 & - & - \\
\hline 2016 indicator & 0.72 & 24.33 & -0.37 & -7.26 & -0.07 & -2.06 & 0.39 & 11.56 & - & - \\
\hline 2017 indicator & 1.02 & 39.73 & -0.91 & -17.21 & -0.13 & -3.71 & 0.51 & 15.54 & - & - \\
\hline 2018 indicator & 0.84 & 29.67 & -0.21 & -4.30 & -0.05 & -1.62 & 1.28 & 30.73 & 0.48 & 17.40 \\
\hline 2019 indicator & 0.29 & 10.26 & 0.43 & 9.08 & 0.32 & 9.17 & 0.78 & 20.95 & 0.06 & 2.06 \\
\hline Monday & 0.16 & 5.20 & -0.01 & -0.13 & 0.15 & 4.17 & -0.01 & -0.35 & 0.00 & -0.10 \\
\hline Tuesday & 0.04 & 1.47 & 0.00 & -0.01 & 0.02 & 0.65 & 0.01 & 0.36 & 0.07 & 1.78 \\
\hline Thursday & 0.09 & 3.15 & 0.06 & 1.17 & 0.11 & 3.40 & 0.06 & 1.72 & 0.08 & 1.88 \\
\hline Friday & 0.36 & 13.07 & 0.18 & 3.65 & 0.44 & 13.32 & 0.37 & 10.26 & 0.28 & 6.79 \\
\hline Saturday & 0.92 & 31.72 & 0.39 & 6.62 & 0.97 & 25.10 & 0.91 & 26.38 & 0.55 & 12.46 \\
\hline Sunday & 0.74 & 24.78 & 0.23 & 4.24 & 0.76 & 17.63 & 0.67 & 19.48 & 0.53 & 11.56 \\
\hline
\end{tabular}


Table D.5 (Continued)

\begin{tabular}{|c|c|c|c|c|c|c|c|c|c|c|}
\hline January indicator & -0.23 & -2.48 & -0.65 & -3.71 & -1.29 & -10.34 & - & - & -0.58 & -5.89 \\
\hline February indicator & -0.33 & -3.69 & -0.63 & -3.65 & -1.18 & -9.47 & - & - & -0.49 & -5.50 \\
\hline March indicator & 0.15 & 1.82 & -0.14 & -0.81 & -0.76 & -7.04 & - & - & -0.47 & -4.74 \\
\hline April indicator & 0.22 & 3.50 & 0.42 & 3.10 & -0.78 & -8.87 & -0.52 & -5.64 & -0.39 & -5.91 \\
\hline May indicator & 0.06 & 1.44 & 0.25 & 2.74 & -0.40 & -6.53 & -0.20 & -3.51 & -0.56 & -9.64 \\
\hline June indicator & -0.01 & -0.28 & 0.16 & 2.64 & -0.17 & -4.20 & -0.03 & -1.14 & -0.38 & -6.65 \\
\hline August indicator & -0.09 & -3.45 & -0.08 & -1.59 & -0.10 & -3.13 & -0.16 & -7.25 & 0.11 & 2.29 \\
\hline September indicator & -0.31 & -10.96 & -0.04 & -0.89 & -0.40 & -10.53 & -0.41 & -15.41 & 0.06 & 1.12 \\
\hline October indicator & -0.15 & -3.70 & 0.21 & 2.90 & -0.42 & -8.04 & -0.32 & -6.03 & -0.06 & -1.26 \\
\hline November indicator & -0.19 & -3.03 & 0.24 & 2.21 & -0.67 & -8.32 & -0.52 & -4.55 & -0.33 & -5.58 \\
\hline December indicator & -0.22 & -2.69 & -0.04 & -0.25 & -1.00 & -9.58 & - & - & -0.58 & -6.99 \\
\hline $\begin{array}{l}\text { New Year's Day (actual days, } \\
\text { including weekend) }\end{array}$ & 0.56 & 4.66 & -0.29 & -0.59 & 0.34 & 3.46 & - & - & 0.91 & 8.56 \\
\hline $\begin{array}{l}\text { New Year's Day Observed (only } \\
\text { observed days, Friday or Monday) }\end{array}$ & -0.34 & -1.40 & 1.10 & 12.91 & 0.61 & 8.93 & - & - & - & - \\
\hline New Year's Day*Weekend & -0.53 & -4.52 & 1.27 & 2.61 & -0.12 & -1.13 & - & - & - & - \\
\hline New Year's Eve & 0.53 & 2.60 & 0.03 & 0.11 & 0.13 & 0.48 & - & - & 0.65 & 3.86 \\
\hline Thanksgiving Day & 0.39 & 3.22 & -0.37 & -1.22 & 0.20 & 1.45 & -1.96 & -12.16 & -0.25 & -0.48 \\
\hline Day After Thanksgiving & 0.71 & 7.76 & -0.36 & -1.72 & -0.02 & -0.04 & -2.13 & -13.44 & 0.11 & 0.46 \\
\hline Christmas Day & 0.55 & 3.92 & -1.41 & -2.37 & 0.21 & 0.83 & - & - & 0.66 & 3.83 \\
\hline Christmas Day Observed & 0.74 & 15.65 & -0.58 & -6.65 & 0.93 & 12.46 & - & - & - & - \\
\hline Christmas Day*Weekend & -0.16 & -1.17 & 0.81 & 1.36 & -2.31 & -9.10 & - & - & - & - \\
\hline Christmas Eve & -0.22 & -1.21 & -0.75 & -3.93 & -0.34 & -0.89 & - & - & 0.07 & 0.43 \\
\hline Martin Luther King's Day & 0.25 & 2.37 & 0.12 & 0.28 & 0.02 & 0.06 & - & - & 0.68 & 4.25 \\
\hline Memorial Day & 0.75 & 14.26 & 0.17 & 0.74 & 1.16 & 10.20 & 0.69 & 4.99 & 0.79 & 10.70 \\
\hline President Day & 0.65 & 2.25 & 0.36 & 1.82 & 0.02 & 0.08 & - & - & 0.43 & 1.138 \\
\hline
\end{tabular}


Table D.5 (Continued)

\begin{tabular}{|c|c|c|c|c|c|c|c|c|c|c|}
\hline Independence Day & 0.94 & 13.78 & 0.72 & 7.69 & 0.85 & 5.54 & 0.87 & 9.73 & 0.55 & 2.82 \\
\hline Independence Day Observed & 0.91 & 21.34 & -0.97 & -14.53 & 0.87 & 18.89 & 0.23 & 6.18 & - & - \\
\hline Independence Day*Weekend & -0.06 & -0.71 & -2.24 & -20.01 & -0.53 & -3.38 & -0.79 & -8.29 & - & - \\
\hline Labor Day & 0.67 & 6.36 & 0.54 & 1.81 & 0.74 & 4.41 & 1.01 & 13.83 & 0.59 & 3.20 \\
\hline Columbus Day & 0.37 & 3.98 & 0.00 & -0.01 & 0.57 & 7.84 & 0.07 & 0.43 & -0.03 & -0.33 \\
\hline Veterans Day & 0.26 & 2.74 & 0.24 & 0.79 & -0.17 & -0.73 & 1.03 & 3.11 & 0.00 & 0.03 \\
\hline Veterans Day Observed & 0.62 & 11.17 & 0.13 & 1.29 & 0.43 & 7.78 & 0.81 & 3.34 & 0.48 & 8.10 \\
\hline Veterans Day*Weekend & 0.07 & 0.55 & 0.09 & 0.27 & 0.15 & 0.44 & -1.77 & -8.21 & 0.21 & 2.45 \\
\hline Good Friday & 0.26 & 3.07 & 0.345 & 1.46 & 0.36 & 1.38 & - & - & 0.11 & 0.84 \\
\hline Saturday Before Presidents Day & 0.41 & 2.90 & 0.53 & 1.40 & 0.10 & 0.52 & - & - & 0.49 & 2.20 \\
\hline Sunday Before Presidents Day & 0.79 & 4.42 & 0.59 & 2.37 & -0.13 & -0.37 & - & - & 0.45 & 3.42 \\
\hline Saturday Before Memorial Day & 0.06 & 1.44 & 0.17 & 0.51 & 0.25 & 2.75 & - & - & 0.22 & 1.58 \\
\hline Sunday Before Memorial Day & 0.47 & 8.57 & 0.27 & 0.75 & 0.71 & 5.52 & - & - & 0.12 & 1.5037 \\
\hline Saturday Before Labor Day & 0.26 & 1.41 & -0.13 & -0.41 & 0.37 & 1.95 & 0.22 & 1.77 & -0.14 & -0.59 \\
\hline Sunday Before Labor Day & 0.53 & 7.35 & -0.09 & -0.25 & 0.78 & 7.32 & 0.12 & 1.02 & 0.10 & 0.68 \\
\hline Saturday Before Columbus Day & 0.04 & 0.45 & 0.06 & 0.33 & 0.05 & 0.60 & 0.41 & 2.07 & -0.16 & -0.63 \\
\hline Sunday Before Columbus Day & 0.24 & 2.54 & -0.13 & -0.39 & 0.46 & 4.78 & 0.13 & 1.75 & 0.29 & 1.00 \\
\hline Saturday Before MLK Day & 0.07 & 0.26 & -0.21 & -0.49 & -0.50 & -1.33 & 0.53 & 5.17 & 0.26 & 1.91 \\
\hline Sunday Before MLK Day & 0.19 & 1.60 & 0.39 & 3.30 & -0.08 & -0.57 & 0.14 & 1.04 & 0.07 & 0.56 \\
\hline Cherry Blossom Festival Saturday & 0.31 & 3.61 & - & - & - & - & 0.17 & 1.41 & - & - \\
\hline Cherry Blossom Festival Weekday & 0.12 & 3.04 & - & - & - & - & - & - & - & - \\
\hline $\begin{array}{l}\text { Quadratic effects of maximum } \\
\text { temperature (NOAA Data) }\end{array}$ & 0.00 & 1.49 & 0.00 & -1.21 & 0.00 & 4.41 & 0.00 & 2.57 & -0.01 & -3.35 \\
\hline $\begin{array}{l}\text { Cubic effects of maximum } \\
\text { temperature (NOAA Data) }\end{array}$ & 0.00 & -4.02 & 0.00 & -0.78 & 0.00 & -7.20 & 0.00 & -4.32 & 0.00 & 3.09 \\
\hline $\mathrm{I}(\mathrm{PRCP}>0 \& \mathrm{SNOW}==0)$ & -0.10 & -4.22 & -0.14 & -3.56 & -0.20 & -5.74 & -0.11 & -4.30 & - & - \\
\hline
\end{tabular}


Table D.5 (Continued)

\begin{tabular}{|c|c|c|c|c|c|c|c|c|c|c|}
\hline $\mathrm{I}(\mathrm{PRCP}>0$ \& SNOW $==0) * \mathrm{PRCP}$ & -0.87 & -8.69 & -0.95 & -5.80 & -0.53 & -5.34 & -0.48 & -6.92 & - & - \\
\hline $\begin{array}{l}\mathrm{I}(\mathrm{PRCP}>0 \text { \& } \mathrm{SNOW}==0) * \\
\mathrm{PRCP}^{\wedge} 2\end{array}$ & 0.16 & 3.17 & 0.23 & 2.40 & 0.02 & 0.50 & 0.10 & 3.50 & - & - \\
\hline $\mathrm{I}(\mathrm{SNOW}>0)$ & -0.31 & -2.63 & -0.35 & -2.66 & -0.129 & -1.96 & -0.22 & -1.34 & - & - \\
\hline Number of Observation & \multicolumn{2}{|c|}{$2,844.00$} & \multicolumn{2}{|c|}{$1,634.00$} & \multicolumn{2}{|c|}{$1,759.00$} & \multicolumn{2}{|c|}{$1,676.00$} & \multicolumn{2}{|c|}{922.00} \\
\hline R-Squared & \multicolumn{2}{|c|}{0.88} & \multicolumn{2}{|c|}{0.86} & \multicolumn{2}{|c|}{0.9409} & \multicolumn{2}{|c|}{0.88} & \multicolumn{2}{|c|}{0.56} \\
\hline Adjusted R-Squared & \multicolumn{2}{|c|}{0.88} & \multicolumn{2}{|c|}{0.86} & \multicolumn{2}{|c|}{0.94} & \multicolumn{2}{|c|}{0.88} & \multicolumn{2}{|c|}{0.53} \\
\hline Durbin Watson's Test & \multicolumn{2}{|c|}{1.34} & \multicolumn{2}{|c|}{1.03} & \multicolumn{2}{|c|}{1.52} & \multicolumn{2}{|c|}{1.23} & \multicolumn{2}{|c|}{0.86} \\
\hline MAPE & \multicolumn{2}{|c|}{0.32} & \multicolumn{2}{|c|}{0.52} & \multicolumn{2}{|c|}{0.37} & \multicolumn{2}{|c|}{0.31} & \multicolumn{2}{|c|}{0.29} \\
\hline AIC & \multicolumn{2}{|c|}{$2,857.86$} & \multicolumn{2}{|c|}{$2,967.22$} & \multicolumn{2}{|c|}{$2,237.19$} & \multicolumn{2}{|c|}{$1,583.53$} & \multicolumn{2}{|c|}{799.11} \\
\hline
\end{tabular}

Table D.6: Non-Member Special Event Model

\begin{tabular}{|c|c|c|c|c|c|c|c|c|c|c|}
\hline \multirow[t]{2}{*}{ Variable Description } & \multicolumn{2}{|c|}{$\begin{array}{l}\text { Capital Bikeshare } \\
\text { Washington D.C. }\end{array}$} & \multicolumn{2}{|c|}{ Divvy Chicago } & \multicolumn{2}{|c|}{$\begin{array}{c}\text { Bluebike } \\
\text { Boston }\end{array}$} & \multicolumn{2}{|c|}{$\begin{array}{c}\text { Nice Ride } \\
\text { Minneapolis }\end{array}$} & \multicolumn{2}{|c|}{$\begin{array}{c}\text { Metro } \\
\text { Los Angeles }\end{array}$} \\
\hline & Mean & t-stat & Mean & t-stat & Mean & t-stat & Mean & t-stat & Mean & t-stat \\
\hline Constant & 1.47 & 3.44 & 0.81 & 1.53 & 3.21 & 12.53 & 2.48 & 3.15 & -3.17 & -0.53 \\
\hline $\begin{array}{l}\text { New Year's Day (actual days, } \\
\text { including weekend) }\end{array}$ & 0.58 & 4.92 & -0.26 & -0.54 & 0.37 & 3.72 & - & - & 0.86 & 10.91 \\
\hline $\begin{array}{l}\text { New Year's Day Observed } \\
\text { (only observed days, Friday or } \\
\text { Monday) }\end{array}$ & -0.32 & -1.34 & 1.14 & 13.22 & 0.66 & 9.15 & - & - & - & - \\
\hline New Year's Day*Weekend & -0.56 & -4.87 & 1.24 & 2.58 & -0.12 & -1.14 & - & - & - & - \\
\hline New Year's Eve & 0.53 & 2.54 & 0.02 & 0.06 & 0.10 & 0.41 & - & - & 0.56 & 3.23 \\
\hline Thanksgiving Day & 0.39 & 3.23 & -0.38 & -1.23 & 0.21 & 1.44 & -0.43 & -2.32 & 0.09 & 0.19 \\
\hline
\end{tabular}


Table D.6 (Continued)

\begin{tabular}{|c|c|c|c|c|c|c|c|c|c|c|}
\hline & & & & & & & & & & \\
\hline Day After Thanksgiving & 0.71 & 7.82 & -0.36 & -1.7 & -0.01 & -0.02 & -1.09 & -8.08 & 0.04 & 0.15 \\
\hline Christmas Day & 0.54 & 3.84 & -1.41 & -2.38 & 0.17 & 0.61 & - & - & 0.79 & 4.28 \\
\hline Christmas Day Observed & 0.74 & 15.84 & -0.58 & -6.59 & 0.94 & 12.27 & - & - & - & - \\
\hline Christmas Day*Weekend & -0.19 & -1.36 & 0.78 & 1.32 & -2.24 & -8.00 & - & - & - & - \\
\hline Christmas Eve & -0.23 & -1.28 & -0.76 & -3.92 & -0.34 & -0.91 & - & - & -0.07 & -0.44 \\
\hline Martin Luther King's Day & 0.21 & 1.72 & 0.04 & 0.11 & 0.00 & -0.01 & - & - & 0.34 & 3.48 \\
\hline Memorial Day & 0.73 & 14.16 & 0.18 & 0.77 & 1.09 & 10.02 & 0.69 & 4.99 & 0.78 & 11.11 \\
\hline President Day & 0.61 & 2.17 & 0.28 & 1.4 & 0.01 & 0.03 & - & - & 0.21 & 0.51 \\
\hline Independence Day & 0.94 & 13.61 & 0.73 & 7.79 & 0.84 & 5.53 & 0.88 & 9.84 & 0.56 & 2.93 \\
\hline Independence Day Observed & 0.93 & 21.79 & -0.96 & -14.44 & 0.88 & 19.28 & 0.24 & 6.62 & - & - \\
\hline Independence Day*Weekend & -0.05 & -0.61 & -2.25 & -20.15 & -0.50 & -3.23 & -0.82 & -8.62 & - & - \\
\hline Labor Day & 0.65 & 6.17 & 0.56 & 1.85 & 0.70 & 4.21 & 1 & 13.4 & 0.61 & 3.12 \\
\hline Columbus Day & 0.36 & 3.93 & 0.004 & 0.04 & 0.55 & 7.05 & 0.07 & 0.49 & -0.05 & -0.43 \\
\hline Veterans Day & 0.27 & 2.81 & 0.24 & 0.79 & -0.19 & -0.83 & 0.86 & 2.96 & -0.06 & -1.06 \\
\hline Veterans Day Observed & 0.62 & 11.15 & 0.13 & 1.21 & 0.44 & 8.10 & 0.91 & 4.31 & 0.51 & 10.82 \\
\hline Veterans Day*Weekend & 0.03 & 0.26 & 0.08 & 0.26 & 0.21 & 0.64 & -1.47 & -7.68 & 0.26 & 3.56 \\
\hline Good Friday & 0.27 & 3.11 & 0.34 & 1.41 & 0.36 & 1.39 & 0.18 & 1.39 & 0.03 & 0.31 \\
\hline CicLAvia: Heart of LA & - & - & - & - & - & - & - & - & 1.01 & 12.57 \\
\hline Aquatennial Fireworks & - & - & - & - & - & - & 0.04 & 0.67 & - & - \\
\hline
\end{tabular}


Table D.6 (Continued)

\begin{tabular}{|c|c|c|c|c|c|c|c|c|c|c|}
\hline St. Patrick's Day Parade & 0.26 & 2.18 & 0.12 & 0.5 & -0.06 & -0.51 & - & - & - & - \\
\hline Lollapalooza & - & - & - & - & 0.06 & 0.93 & - & - & - & - \\
\hline Marathon & - & - & 0.13 & 0.3 & 0.46 & 5.03 & - & - & - & - \\
\hline Air and Water Show & - & - & - & - & 0.12 & 1.72 & - & - & - & - \\
\hline Pride Parade & -0.06 & -0.58 & -0.21 & -1.09 & 0.20 & 1.62 & -0.02 & -0.22 & 0.02 & 0.15 \\
\hline Jazz Festival Saturday & - & - & - & - & 0.46 & 3.41 & - & - & - & - \\
\hline Jazz Festival Sunday & - & - & - & - & 0.69 & 4.11 & - & - & - & - \\
\hline $\begin{array}{l}\text { Cherry Blossom Festival } \\
\text { Saturday }\end{array}$ & 0.30 & 3.57 & - & - & - & - & - & - & - & - \\
\hline $\begin{array}{l}\text { Cherry Blossom Festival } \\
\text { Weekday }\end{array}$ & 0.13 & 3.28 & - & - & - & - & - & - & - & - \\
\hline H-Street Festival & 0.13 & 1.78 & - & - & - & - & - & - & - & - \\
\hline Monday & 0.15 & 5.30 & -0.01 & -0.22 & 0.16 & 4.59 & -0.01 & -0.31 & -0.002 & -0.06 \\
\hline Tuesday & 0.04 & 1.34 & 0.01 & 0.23 & 0.02 & 0.49 & 0.01 & 0.46 & 0.07 & 1.84 \\
\hline Thursday & 0.09 & 3.23 & 0.06 & 1.26 & 0.12 & 3.58 & 0.05 & 1.69 & 0.08 & 2.24 \\
\hline Friday & 0.35 & 13.16 & 0.18 & 3.67 & 0.44 & 13.36 & 0.36 & 10.13 & 0.27 & 7.09 \\
\hline Saturday & 0.93 & 32.74 & 0.40 & 7.00 & 0.97 & 25.33 & 0.92 & 28.45 & 0.56 & 14.15 \\
\hline Sunday & 0.78 & 26.84 & 0.25 & 4.67 & 0.76 & 17.75 & 0.71 & 22.11 & 0.51 & 13.29 \\
\hline Number of Observation & \multicolumn{2}{|c|}{2848.00} & \multicolumn{2}{|c|}{1700.00} & \multicolumn{2}{|c|}{1760.00} & \multicolumn{2}{|c|}{1727.00} & \multicolumn{2}{|c|}{975.00} \\
\hline R-Squared & \multicolumn{2}{|c|}{0.88} & \multicolumn{2}{|c|}{0.86} & \multicolumn{2}{|c|}{0.94} & \multicolumn{2}{|c|}{0.89} & \multicolumn{2}{|c|}{0.62} \\
\hline
\end{tabular}


Table D.6 (Continued)

\begin{tabular}{|l|c|c|c|c|c|}
\hline Adjusted R-Squared & 0.88 & 0.86 & 0.94 & 0.89 & 0.61 \\
\hline Durbin Watson's Test & 1.28 & 1.02 & 1.49 & 1.27 & 0.81 \\
\hline MAPE & 0.32 & 0.53 & 0.36 & 0.31 & 0.26 \\
\hline
\end{tabular}

